Review Article

\title{
Carbon Dioxide Separation from Flue Gases: A Technological Review Emphasizing Reduction in Greenhouse Gas Emissions
}

\author{
Mohammad Songolzadeh, ${ }^{1}$ Mansooreh Soleimani, ${ }^{1}$ \\ Maryam Takht Ravanchi, ${ }^{2}$ and Reza Songolzadeh ${ }^{3}$ \\ ${ }^{1}$ Department of Chemical Engineering, Amirkabir University of Technology, P.O. Box 15875-4413, Tehran, Iran \\ ${ }^{2}$ Catalyst Research Group, Petrochemical Research and Technology Company, National Petrochemical Company, \\ P.O. Box 1435884711, Tehran, Iran \\ ${ }^{3}$ Department of Petroleum Engineering, Petroleum University of Technology, P.O. Box 6198144471, Ahwaz, Iran
}

Correspondence should be addressed to Mansooreh Soleimani; soleimanim@aut.ac.ir

Received 17 August 2013; Accepted 31 October 2013; Published 17 February 2014

Academic Editors: D.-W. Han and V. A. Rogov

Copyright (C) 2014 Mohammad Songolzadeh et al. This is an open access article distributed under the Creative Commons Attribution License, which permits unrestricted use, distribution, and reproduction in any medium, provided the original work is properly cited.

\begin{abstract}
Increasing concentrations of greenhouse gases (GHGs) such as $\mathrm{CO}_{2}$ in the atmosphere is a global warming. Human activities are a major cause of increased $\mathrm{CO}_{2}$ concentration in atmosphere, as in recent decade, two-third of greenhouse effect was caused by human activities. Carbon capture and storage (CCS) is a major strategy that can be used to reduce GHGs emission. There are three methods for CCS: pre-combustion capture, oxy-fuel process, and post-combustion capture. Among them, post-combustion capture is the most important one because it offers flexibility and it can be easily added to the operational units. Various technologies are used for $\mathrm{CO}_{2}$ capture, some of them include: absorption, adsorption, cryogenic distillation, and membrane separation. In this paper, various technologies for post-combustion are compared and the best condition for using each technology is identified.
\end{abstract}

\section{Introduction}

There are ten primary GHGs including water vapor $\left(\mathrm{H}_{2} \mathrm{O}\right)$, carbon dioxide $\left(\mathrm{CO}_{2}\right)$, methane $\left(\mathrm{CH}_{4}\right)$, and nitrous oxide $\left(\mathrm{N}_{2} \mathrm{O}\right)$ that are naturally occurring. Perfluorocarbons $\left(\mathrm{CF}_{4}, \mathrm{C}_{2} \mathrm{~F}_{6}\right)$, hydrofluorocarbons $\left(\mathrm{CHF}_{3}, \mathrm{CF}_{3} \mathrm{CH}_{2} \mathrm{~F}\right.$, and $\left.\mathrm{CH}_{3} \mathrm{CHF}_{2}\right)$, and sulfur hexafluoride $\left(\mathrm{SF}_{6}\right)$, are only present in the atmosphere due to industrial processes. Water vapor is the most important, abundant and dominant greenhouse gas, and $\mathrm{CO}_{2}$ is the second-most important one (Table 1). Concentration of water vapor depends on temperature and other meteorological conditions, and not directly upon human activities. So it was not indicated in Table 1 [1-3].

$\mathrm{CO}_{2}$ is the primary anthropogenic greenhouse gas, accounting for $77 \%$ of the human contribution to the greenhouse effect in recent decade (26 to 30 percent of all $\mathrm{CO}_{2}$ emissions). Main anthropogenic emissions of $\mathrm{CO}_{2}$ come from the combustion of fossil fuels. $\mathrm{CO}_{2}$ concentration in flue gases depends on the fuel such as coal (12-15 mol$\% \mathrm{CO}_{2}$ ) and natural gas (3-4 mol- $\left.\% \mathrm{CO}_{2}\right)$. In petroleum and other industrial plants, $\mathrm{CO}_{2}$ concentration in exhaust stream depends on the process such as oil refining (8-9 mol\% $\mathrm{CO}_{2}$ ) and production of cement (14-33 mol- $\% \mathrm{CO}_{2}$ ) and iron and steel (20-44 mol-\%). From 2004 to 2011, global $\mathrm{CO}_{2}$ emissions from energy uses were increased $26 \%$ (Figure 1) [4-10]. Figure 2 indicates that power plant (55\% of global $\mathrm{CO}_{2}$ emissions), transportation (23\%), and industry (19\%) have highest share in the $\mathrm{CO}_{2}$ emission in USA. Cement and petrochemical plants are two major industries for $\mathrm{CO}_{2}$ emission, such that cement industry contributes about $5 \%$ to global anthropogenic $\mathrm{CO}_{2}$ emissions. Also, petrochemical industries are a large share of $\mathrm{CO}_{2}$ emission; for example, only in Iran, petrochemical industries emission was about $15 \mathrm{Mton}$ $\mathrm{CO}_{2}$ /year [11-16].

The Kyoto Protocol is the first international agreement on emissions of GHGs. In this protocol, industrialized countries agreed to stabilize or reduce the GHGs emissions in the commitment period $2008-2012$ by $5.2 \%$ on average (compared to their 1990 emissions level). Overall, the result of global $\mathrm{CO}_{2}$ emissions (Figure 1) shows the failure of 
TABLE 1: The main greenhouse gases and their concentration $[2,3]$.

\begin{tabular}{|c|c|c|c|c|c|}
\hline Compound & $\begin{array}{c}\text { Preindustrial } \\
\text { concentration (ppmv) }\end{array}$ & $\begin{array}{l}\text { Concentration } \\
\text { in } 2011 \text { (ppmv) }\end{array}$ & $\begin{array}{c}\text { Atmospheric } \\
\text { lifetime (years) }\end{array}$ & Main human activity source & $\mathrm{GWP}^{* *}$ \\
\hline Carbon dioxide $\left(\mathrm{CO}_{2}\right)$ & 280 & 388.5 & $\sim 100$ & Fossil fuels, cement production, land use & 1 \\
\hline Methane $\left(\mathrm{CH}_{4}\right)$ & 0.715 & $1.87 / 1.748$ & 12 & $\begin{array}{l}\text { Fossil fuels, rice paddies, waste dumps, } \\
\text { livestock }\end{array}$ & 25 \\
\hline Nitrous oxide $\left(\mathrm{N}_{2} \mathrm{O}\right)$ & 0.27 & 0.323 & 114 & Fertilizers, combustion industrial processes & 298 \\
\hline $\mathrm{CFC}-12\left(\mathrm{CCL}_{2} \mathrm{~F}_{2}\right)$ & 0 & 0.000533 & 100 & Liquid coolants, foams & 10,900 \\
\hline CF-113 $\left(\mathrm{CCl}_{2} \mathrm{CClF}_{2}\right)$ & 0 & 0.00000075 & 85 & n.a. & 6,130 \\
\hline $\mathrm{HFC} 23\left(\mathrm{CHF}_{3}\right)$ & 0 & 0.000018 & 270 & Electronics, refrigerants & 11,700 \\
\hline $\mathrm{HCFC}-22\left(\mathrm{CCl}_{2} \mathrm{~F}_{2}\right)$ & 0 & 0.000218 & 12 & Refrigerants & 1,810 \\
\hline $\mathrm{HFC} 134\left(\mathrm{CF}_{3} \mathrm{CH}_{2} \mathrm{~F}\right)$ & 0 & 0.000035 & 14 & Refrigerants & 1,300 \\
\hline HCFC-141b $\left(\mathrm{CH}_{3} \mathrm{CCl}_{2} \mathrm{~F}\right)$ & 0 & 0.00000022 & 9.3 & n.a. & 725 \\
\hline HCFC-142b $\left(\mathrm{CH}_{3} \mathrm{CClF}_{2}\right)$ & 0 & 0.00000020 & 17.9 & n.a. & 2,310 \\
\hline HFC $152\left(\mathrm{CH}_{3} \mathrm{CHF}_{2}\right)$ & 0 & 0.0000039 & 1.4 & Industrial processes & 140 \\
\hline Perfluoromethane $\left(\mathrm{CF}_{4}\right)$ & 0.00004 & $0.00008^{*}$ & 50,000 & Aluminum production & 6,500 \\
\hline Perfluoroethane $\left(\mathrm{C}_{2} \mathrm{~F}_{6}\right)$ & 0 & $0.000003^{*}$ & 10,000 & Aluminum production & 9,200 \\
\hline Sulfur hexafluoride $\left(\mathrm{SF}_{6}\right)$ & 0 & $0.00000712^{*}$ & 3,200 & Dielectric fluid & 22,800 \\
\hline
\end{tabular}

${ }^{*}$ Concentration in 2011.

** Global warming potentials (GWPs) measure the relative effectiveness of GHGs in trapping the Earth's heat.

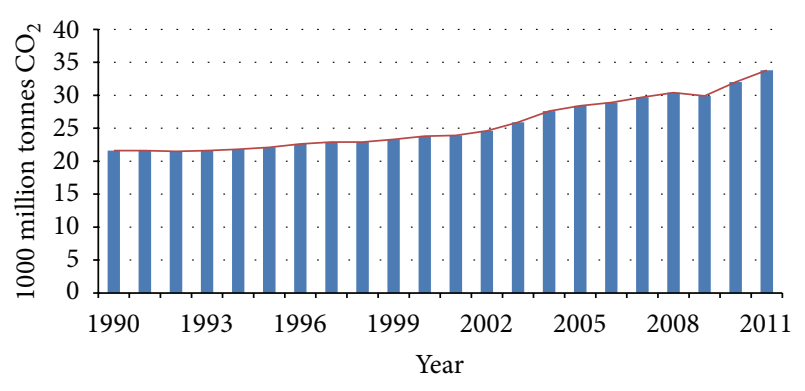

FIGURE 1: Global $\mathrm{CO}_{2}$ emissions from fossil fuel combustion and cement production [23].

Kyoto protocol; therefore, in 2011 Durban COP meeting, this protocol was extended until 2017. Several countries with high GHGs emission like China, India, Brazil, and even Iran have added to this Protocol. Intergovernmental Panel on Climate Change (IPCC) predicted the atmosphere may contain up to 570 ppmv $\mathrm{CO}_{2}$ by the year 2100 , causing a rise of mean global temperature and sea level around $1.9^{\circ} \mathrm{C}$ and $38 \mathrm{~m}$, respectively $[15,17-20]$. Given that the earth's average temperature continues to rise, Intergovernmental Panel on Climate Change (IPCC) stated, global GHG emissions must be reduced by 50 to 80 percent by 2050 to avoid dramatic consequences of global warming [21-23].

Carbon capture and storage (CCS) is the most indicated technology to decrease $\mathrm{CO}_{2}$ emission from fossil fuels sources to atmosphere. Also, $\mathrm{CO}_{2}$ separated from flue gases can be used in enhanced oil recovery (EOR) operations where $\mathrm{CO}_{2}$ is injected into oil reservoirs to increase mobility of oil and reservoir recovery $[24,25]$. Pure $\mathrm{CO}_{2}$ has many applications in food/beverage and different chemical industries such as urea and fertilizer production, foam blowing,

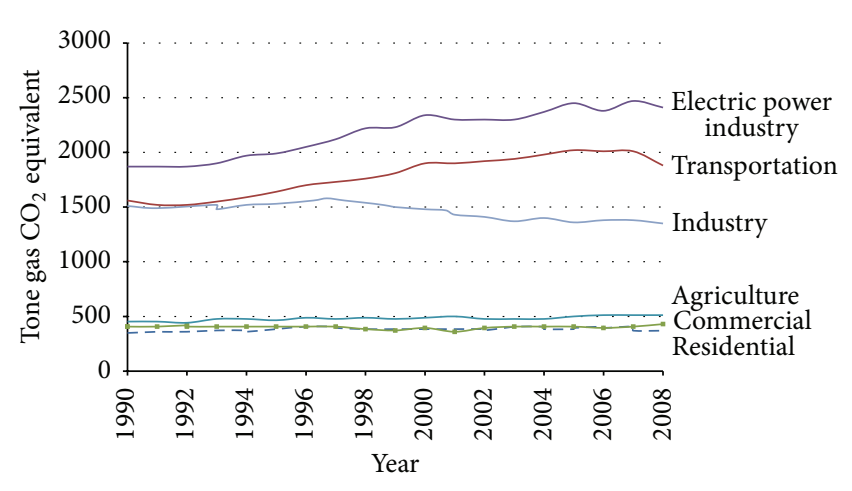

FIGURE 2: U.S. GHG Emissions Allocated to Economic Sectors [2].

carbonation of beverages and dry ice production, or even in the supercritical state as supercritical solvent [26-28].

From this definition, CCS consists of three basic stages: (a) separation of $\mathrm{CO}_{2}$, (b) transportation, and (c) storage. Operating costs of these stages have been estimated in 2008:

(i) $\mathrm{CO}_{2}$ separation from exhausting gases: 24 to $52 € /$ ton- $\mathrm{CO}_{2}$,

(ii) transportation to storage location: 1 to $6 € /$ ton- $\mathrm{CO}_{2}$ per $100 \mathrm{~km}$,

(iii) storage: -28 to $42 € /$ ton $-\mathrm{CO}_{2}$.

Therefore, $\mathrm{CO}_{2}$ separation is a major stage in CCS. The CCS total costs can vary from -3 to $106 € /$ ton- $\mathrm{CO}_{2}$ (negative values are expected for the injection of $\mathrm{CO}_{2}$ in $\mathrm{EOR}$ ). There are three major approaches for CCS: pre-combustion capture, oxy-fuel process, and post-combustion capture (Figure 3 ) $[25,30,31]$. 
Post-combustion capture

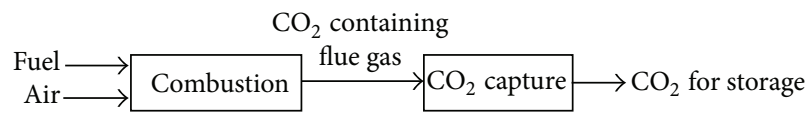

Oxy fuel combustion

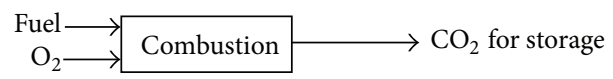

Pre-combustion capture

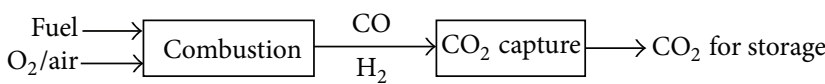

FIgure 3: Three basic approaches of $\mathrm{CO}_{2}$ capture [29].

Pre-combustion capture involves reaction of a fuel with oxygen or air and in some cases steam to produce a gas mainly composed of carbon monoxide and hydrogen, which is known as synthesis gas (syngas) or fuel gas. The produced carbon monoxide is reacted with steam in a catalytic reactor, called shift converter, to give $\mathrm{CO}_{2}$ and more hydrogen. $\mathrm{CO}_{2}$ is then separated, usually by cryogenic distillation or chemical absorption process, resulting in a hydrogen-rich fuel that can be used in many applications, such as furnaces, gas turbines, engines and fuel cells [32, 33].

A main advantage of post-combustion is the higher $\mathrm{CO}_{2}$ concentration and pressure achieved in the output stream. The main disadvantage of pre-combustion capture is system needs long-term development in a number of enabling technical areas to achieve targeted efficiency towards a hydrogen economy. This disadvantage has limited application of this approach and increased investments costs of pre-combustion capture $[34,35]$.

In oxy-fuel combustion, nearly pure oxygen is used for combustion instead of ambient air, and this results in a flue gas that is mainly $\mathrm{CO}_{2}$ and $\mathrm{H}_{2} \mathrm{O}$, which are separated by condensing water. Three major advantages of this method are high $\mathrm{CO}_{2}$ concentration in output stream (above $80 \% \mathrm{v} / \mathrm{v}$ ), high flame temperature, and easy separation of exhaust gases. The major disadvantages of oxy-fuel combustion are high capital cost and large electric power requirement to separate oxygen from air [36-38].

The principle of post-combustion capture is $\mathrm{CO}_{2}$ separation from flue gas after combustion. Generally, the $\mathrm{CO}_{2}$ in flue gas is diluted $\left(8-15 \% \mathrm{CO}_{2}\right)$ with inert gases such as nitrogen, argon, and water in addition to oxygen. Flue gases are normally at atmospheric pressure and high temperatures (between $320 \mathrm{~K}$ and $400 \mathrm{~K}$ ) [39-41]. Post-combustion capture does not require expensive technologies such as syngas separation, hydrogen turbine, fuel cell. Post-combustion capture is the most important to prevent $\mathrm{CO}_{2}$ emissions, because it offers flexibility and does not need to change combustion cycle. If the capture plant shuts down, the power plant can still operate $[42,43]$. Major disadvantage of this method is unfavorable condition of flue gases.

Because of the importance in selecting suitable process for $\mathrm{CO}_{2}$ separation, in this research various technologies for this purpose have been focused.

\section{2. $\mathrm{CO}_{2}$ Separation Technologies}

Based on economical and environmental considerations, it is necessary to apply efficient and suitable technology for $\mathrm{CO}_{2}$ separation with low operating cost and energy consumption. Up to now, there are several gas separation technologies being investigated for post-combustion capture, namely, (a) absorption, (b) adsorption, (c) cryogenic distillation, and (d) membrane separation (Figure 4) [39, 44]. Although various new methods were suggested for $\mathrm{CO}_{2}$ separation, Granite and Brien [45] reviewed some of the most novel methods for carbon dioxide separation from flue and fuel gas streams, such as use of electrochemical pumps and chemical looping for $\mathrm{CO}_{2}$ separation.

2.1. Absorption. Absorption stripping is an important technology for $\mathrm{CO}_{2}$ capture from fuel gas; in this technology desired component in mixed gases are dissolved in a solvent (bulk phase) [46]. The general scheme of this process is depicted in Figure 5.

The flue gas (containing $\mathrm{CO}_{2}$ ) is cooled (between 318 and $323 \mathrm{~K}$ ), and fed to the absorption column (scrubber) where the solvent absorbs $\mathrm{CO}_{2}$. The $\mathrm{CO}_{2}$-rich solution is fed into a heater to increase the temperature of solution, then to a stripper column to release the $\mathrm{CO}_{2}$. The released $\mathrm{CO}_{2}$ is compressed, and the regenerated absorbent solution is cooled and recycled to the absorber column [47, 48].

Energy required for post-combustion $\mathrm{CO}_{2}$ capture is an important issue. Thus, recent studies suggest that reduction of the cost of this capture could be achieved by finding suitable solvents that could process larger amounts of $\mathrm{CO}_{2}$ for a given mass and require less energy for stripping stage $[49,50]$.

2.1.1. Solvents. In absorption process, flue gas is contacted with a liquid "absorbent" (or "solvent"), and $\mathrm{CO}_{2}$ is absorbed by this solvent [21]. However, the absorbent should have a suitable capacity for $\mathrm{CO}_{2}$ absorption, high kinetic rate for $\mathrm{CO}_{2}$ absorption, negligible vapor pressure, and high chemical and thermal stability and should be harmless for labor persons [51-53].

The solvents used for $\mathrm{CO}_{2}$ absorption can be divided into two categories: physical and chemical solvents. Physical solvent processes use organic solvents to physically absorb acid gas components rather than reacting chemically, but chemical absorption depends on acid-base neutralization reactions using alkaline solvents $[54,55]$. In the recent years, many studies have compared the performance of different solvents as listed in Table 2.

(1) Alkanolamines. Between various solvent groups, alkanolamines group is the most important and more used for $\mathrm{CO}_{2}$ separation. A major problem in the usage of amines for $\mathrm{CO}_{2}$ absorption is equipment corrosion, so Albritton et al. [56] examined corrosion rate of various amine solvents and suggested corrosion rate could reduce in the following order: monoethanolamine (MEA) > 2-amino-2-methyl-1-propanol $($ AMP $)>$ diethanolamine $($ DEA $)>$ methyl diethanolamine (MDEA). 


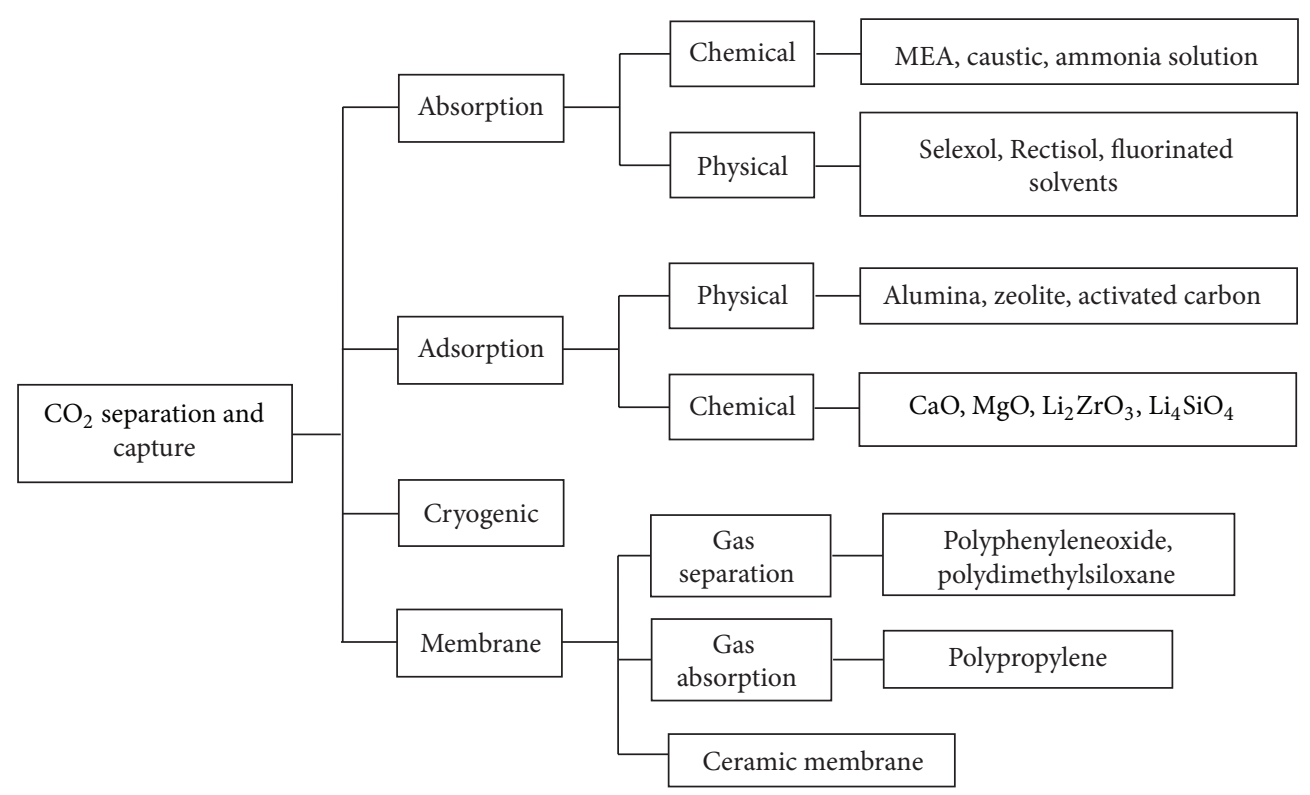

FIGURE 4: Different technologies for $\mathrm{CO}_{2}$ separation [29].

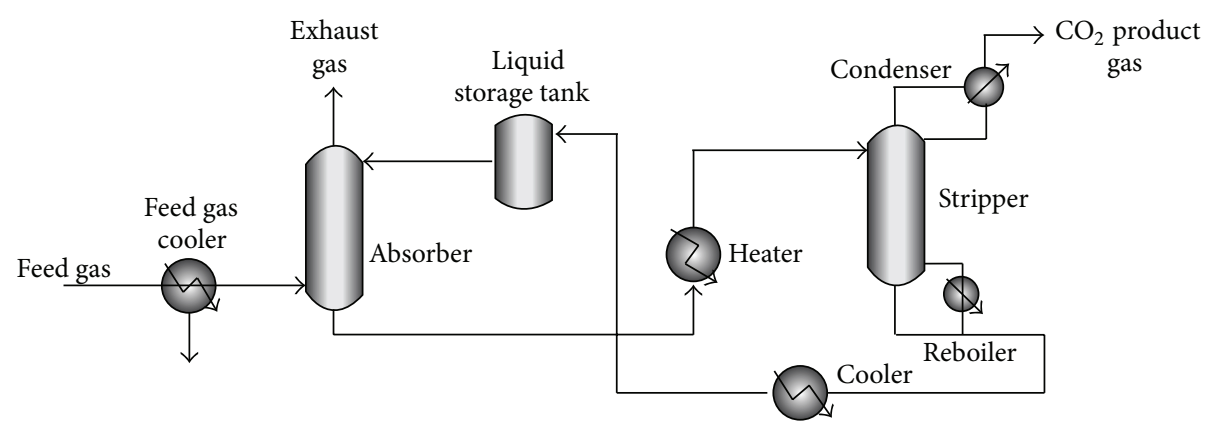

FIgURE 5: Schematic diagram of $\mathrm{CO}_{2}$ absorption pilot plant.

On the other way, MEA can react more quickly with $\mathrm{CO}_{2}$ than MDEA, but MDEA has higher $\mathrm{CO}_{2}$ absorption capacity and requires lower energy to regenerate $\mathrm{CO}_{2}[39,57$, 58]. Thus, it can be concluded that MEA is one of the best amine solvents for $\mathrm{CO}_{2}$ separation. Idem et al. [59] reported substantial reduction in energy requirements and modest reduction in circulation rates for amine blends relative to the corresponding single amine system of similar total amine concentration. Wang et al. [57] found that when MEA and MDEA are mixed at the appropriate ratio, the energy consumption for $\mathrm{CO}_{2}$ regeneration is reduced significantly. Dave et al. [28] compared the performance of several amine solvents and ammonia solutions at various concentrations. They showed that $30 \mathrm{wt} \%$ AMP based process has the lowest overall energy requirement among the solvents considered in their study (30\% MEA, 30\% MDEA, 2.5\% $\mathrm{NH}_{3}$, and 5\% $\mathrm{NH}_{3}$ ) $[28,60]$.

Knudsen et al. [61] studies showed that it is possible to run the post-combustion capture plant continuously while achieving roughly $90 \% \mathrm{CO}_{2}$ separation levels and CASTOR-2 (blended amine solvents), operated in pilot scale with lower steam requirement and liquid-to-gas ratio $(\mathrm{L} / \mathrm{G})$ than the conventional MEA solvent.

Besides alkanolamines, carbonate-bicarbonate buffers and hindered amines are used in the bulk removal of $\mathrm{CO}_{2}$ owing to the low steam requirement for its regeneration. Mitsubishi Heavy Industries and Kansai Electric have employed other patented chemical solvents-strictly hindered amines called KS-1, KS-2, or KS-3. The regeneration heat of KS solvents is said to be $\sim 3 \mathrm{GJ} / \mathrm{t} \mathrm{CO}$, that is, $20 \%$ lower than that of MEA with $~ 3.7 \mathrm{GJ} / \mathrm{t} \mathrm{CO}_{2}[60,64,77]$. Generally, the overall cost of amine absorption/stripping technology for $\mathrm{CO}_{2}$ capture process is $52-77$ US\$/ton $\mathrm{CO}_{2}$ [71].

(2) Amino Acid. Amino acids have the same functional groups as alkanolamines and can be expected to behave similarly towards $\mathrm{CO}_{2}$ but do not deteriorate in the presence of oxygen. Based on the results of tests, the aqueous potassium salts (composed of sarcosine and proline) are considered to be the most promising solvents. The most common amino acids used in the gas treating solvents are glycine, alanine, dimethyl 
TABLE 2: Various solvents suggested for $\mathrm{CO}_{2}$ separation.

\begin{tabular}{|c|c|c|c|c|}
\hline Group of solvents & Advantage & Disadvantage & Application & Reference \\
\hline \multicolumn{5}{|c|}{ Physical } \\
\hline $\begin{array}{l}\text { Dimethyl ether of } \\
\text { polyethylene glycol } \\
\text { (Selexol) }\end{array}$ & \multirow{3}{*}{$\begin{array}{l}\text { (i) Require low energy for } \\
\text { regeneration (less than } 20 \% \text { of } \\
\text { the value for chemical } \\
\text { absorbent) } \\
\text { (ii) Low vapor pressure, low } \\
\text { toxicity, and less corrosive } \\
\text { solvent }\end{array}$} & \multirow{3}{*}{$\begin{array}{l}\text { (i) Dependent on temperature } \\
\text { and pressure; therefore they } \\
\text { are not suitable for } \\
\text { post-combustion process } \\
\text { (ii) Low capacity for } \mathrm{CO}_{2} \\
\text { absorption }\end{array}$} & Natural gas sweetening & \multirow{5}{*}{$\begin{array}{l}{[29,39,57} \\
62,63]\end{array}$} \\
\hline Glycol & & & $\begin{array}{l}\text { Capturing } \mathrm{CO}_{2} \text { and } \mathrm{H}_{2} \mathrm{~S} \text { at } \\
\text { higher concentration }\end{array}$ & \\
\hline Glycol carbonate & & & $\begin{array}{l}\text { Separating } \mathrm{CO}_{2} \text { from other } \\
\text { gases }\end{array}$ & \\
\hline Methanol (Rectisol) & & & $\begin{array}{l}\mathrm{CO}_{2} \text { removal from various } \\
\text { streams }\end{array}$ & \\
\hline Fluorinated solvent & & & $\begin{array}{l}\text { (i) } \mathrm{CO}_{2} \text { removal from various } \\
\text { streams } \\
\text { (ii) Separating } \mathrm{CO}_{2} \text { from } \\
\text { other gases }\end{array}$ & \\
\hline
\end{tabular}

Chemical

$\begin{array}{ll}\text { Alkanolamines: } & \text { (i) React rapidly } \\ \text { monoethanolamine } & \text { (ii) High selectively (between } \\ \text { (MEA), diethanolamine } & \text { acid and other gases) } \\ \text { (DEA), and methyl } & \text { (iii) Reversible absorption } \\ \text { diethanolamine (MDEA) } & \text { process }\end{array}$

diethanolamine (MDEA)

Amino acid and aqueous amino acid salt

Ammonia

Ionic liquid (IL) (i) Low $\mathrm{CO}_{2}$ loading capacity

(ii) Solvent degradation in existence of $\mathrm{SO}_{2}$ and $\mathrm{O}_{2}$ in flue gas (concentrations must be less than $10 \mathrm{ppm}$ and $1 \mathrm{ppm}$ ) (iii) High equipment

(iv) Inexpensive solvent

corrosion rate

(iv) High energy consumption

(i) The possibility of adding a salt functional group.

(ii) The nonvolatility of solvents

(iii) Having high surface tension

(iv) Having better resistance to degradation than other chemical solvents

(v) Better performance than MEA of the same concentration for $\mathrm{CO}_{2}$ absorption

(i) No degradation in the presence of $\mathrm{SO}_{2}$ and $\mathrm{O}_{2}$ in the flue gases

(ii) No corrosion effect

(iii) Require low energy to regeneration ( $1 / 3$ that required with MEA)

(iv) Low costs with aqueous ammonia, respectively, $15 \%$ and 20\% less than with MEA

(i) Very low vapor pressure

(ii) Good thermal stability

(iii) High polarity

(iv) Nontoxicity

Decreased performance in the presence of oxygen

(i) Reversible at lower temperatures (not suitable for post-combustion)

(ii) Production of solid products and their operating problems

(iii) Explosion of dry $\mathrm{CO}_{2}-\mathrm{NH}_{3}$ reaction in the high concentration of $\mathrm{CO}_{2}$ in the flue gas (explosive limit for $\mathrm{NH}_{3}$ gas is $15-28 \%$ )

Increased viscosity with $\mathrm{CO}_{2}$ absorption
Important for removing acidic components from gas streams

$[58,60,61$, 64-66]

Suggested for $\mathrm{CO}_{2}$ separation from flue gases

$[65,67-$

Suggested for $\mathrm{CO}_{2}$ separation from flue gases
Suggested for $\mathrm{CO}_{2}$ separation from flue gases
[71-74] 
TABLE 2: Continued.

\begin{tabular}{|c|c|c|c|c|}
\hline Group of solvents & Advantage & Disadvantage & Application & Reference \\
\hline Aqueous piperazine (PZ) & $\begin{array}{l}\text { (i) Fast absorption kinetics } \\
\left(\mathrm{CO}_{2} \text { absorption rate with }\right. \\
\text { aqueous } \mathrm{PZ} \text { is more than } \\
\text { double that of MEA) } \\
\text { (ii) Low degradation rates for } \\
\mathrm{CO}_{2} \text { separation } \\
\text { (iii) Negligible thermal } \\
\text { degradation in concentrated } \\
\mathrm{PZ} \text { solutions } \\
\text { (iv) Favorable equilibrium } \\
\text { characteristics } \\
\text { (v) Very low heat of } \\
\text { absorption (10-15 kCal/mol } \\
\left.\mathrm{CO}_{2}\right) \text {, } 80-90 \% \text { energy } \\
\text { required for aqueous amine } \\
\text { system }\end{array}$ & $\begin{array}{l}\text { Lower oxidative degradation } \\
\text { of concentrated PZ (i.e., } 4 \\
\text { times slower than MEA in the } \\
\text { presence of the combination of } \\
\mathrm{Fe}^{2+} / \mathrm{Cr}^{3+} / \mathrm{Ni}^{2+} \text { and } \mathrm{Fe}^{2+} / \mathrm{V}^{5+} \text { ) }\end{array}$ & $\begin{array}{l}\text { (i) Effective for treating syngas } \\
\text { at high temperatures } \\
\text { (ii) Application of additional } \\
\text { amine promoters for natural } \\
\text { gas treating and } \mathrm{CO}_{2} \\
\text { separation from flue gases }\end{array}$ & $\begin{array}{c}{[29,66,75} \\
76]\end{array}$ \\
\hline
\end{tabular}

glycine, diethyl glycine, and a number of sterically hindered amino acids $[65,67,68]$.

Results of many research groups showed that these solvents are suitable for application in membrane gas absorption units, because these solvents have better performance and degradation resistance than other chemical solvents [78]. Amino acid salts formed by neutralization of amino acids with an organic base such as amine showed better $\mathrm{CO}_{2}$ absorption potential than amino acid salts from neutralization of amino acid salts from an inorganic base such as potassium hydroxide [79, 80]. Aronu et al. [69] studied the performance of amino acids neutralized with 3(methylamino)propylamine (MAPA), glycine, $\beta$-alanine, and sarcosine. Their results indicated that sarcosine neutralized with MAPA has the best $\mathrm{CO}_{2}$ absorption performance. Its performance is also enhanced by promoting with excess MAPA [69].

(3) Ammonia. Since ammonia is a toxic gas, prevention of ammonia "slip" to the atmosphere is a necessity. Despite this disadvantage, chilled ammonia process (CAP) was used for $\mathrm{CO}_{2}$ separation (Figure 6). In the $\mathrm{CAP}, \mathrm{CO}_{2}$ is absorbed in an ammoniated solution at a lower absorption temperature $(275-283 \mathrm{~K})$ that reduced ammonia emissions from the CAP absorber. Ammonium carbonate solution resulted in approximately $38 \%$ carbon regeneration compared to MEA solution $[70,81,82]$.

(4) Aqueous Piperazine (PZ). Piperazine (PZ) is as an additive used for amine systems to improve kinetics of $\mathrm{CO}_{2}$ absorption, such as MDEA/PZ or MEA/PZ blends. Because PZ solubility in water is low, concentration of $\mathrm{PZ}$ is between 0.5 and 2.5 M. As indicated in Table 2, increasing the concentration of PZ in solution allows for increased solvent capacity and faster kinetic. The presence of potassium in solution increases the concentration of $\mathrm{CO}_{3}{ }^{2-} / \mathrm{HCO}_{3}{ }^{-}$in solution; therefore, solution has buffering property. These competing effects yield a maximum fraction of reactive species at potassium to piperazine ratio of $2: 1[75,83,84]$.
2.2. Adsorption. Adsorption operation can reduce energy and cost of the capture or separation of $\mathrm{CO}_{2}$ in postcombustion capture. To achieve this goal, it is necessary to find adsorbents with suitable properties. In general, $\mathrm{CO}_{2}$ adsorbent must have high selectivity and adsorption capacity and adequate adsorption/desorption kinetics, remain stable after several adsorption/desorption cycles, and possess good thermal and mechanical stability [51, 85-88]. The adsorbents used for $\mathrm{CO}_{2}$ separation placed into two main categories: physical and chemical adsorbents.

2.2.1. Chemical Adsorption. Chemisorption is a subclass of adsorption, driven by a chemical reaction occurring at the exposed surface. Adsorption capacities of different chemical adsorbents are summarized in Table 3.

A wide range of metals have been studied including [89]

(i) metal oxides: $\mathrm{CaO}, \mathrm{MgO}$,

(ii) metal salts from alkali metal compounds: lithium silicate, lithium zirconate to alkaline earth metal compounds (i.e., magnesium oxide and calcium oxide),

(iii) hydrotalcites and double salts.

In general, one mole of metal compound can react with one mole of $\mathrm{CO}_{2}$ with a reversible reaction. The process consists of a series of cycles where metal oxides (such as $\mathrm{CaO}$ ) at $923 \mathrm{~K}$ are transformed into metal carbonates form (such as $\mathrm{CaCO}_{3}$ ) at $1123 \mathrm{~K}$ in a carbonation reactor to regenerate the sorbent and produce a concentrated stream of $\mathrm{CO}_{2}$ suitable for storage $[90,91]$.

Considerable attention was paid to calcium oxide $(\mathrm{CaO})$ as it has a high $\mathrm{CO}_{2}$ adsorption capacity and high raw material availability (e.g., limestone) at a low cost. Lithium salts was recorded a good performance in $\mathrm{CO}_{2}$ adsorption, but it gained less focus due to its high production cost. Although double salts can be easily regenerated due to low energy requirement, their stability has not been investigated $[93,96]$. 


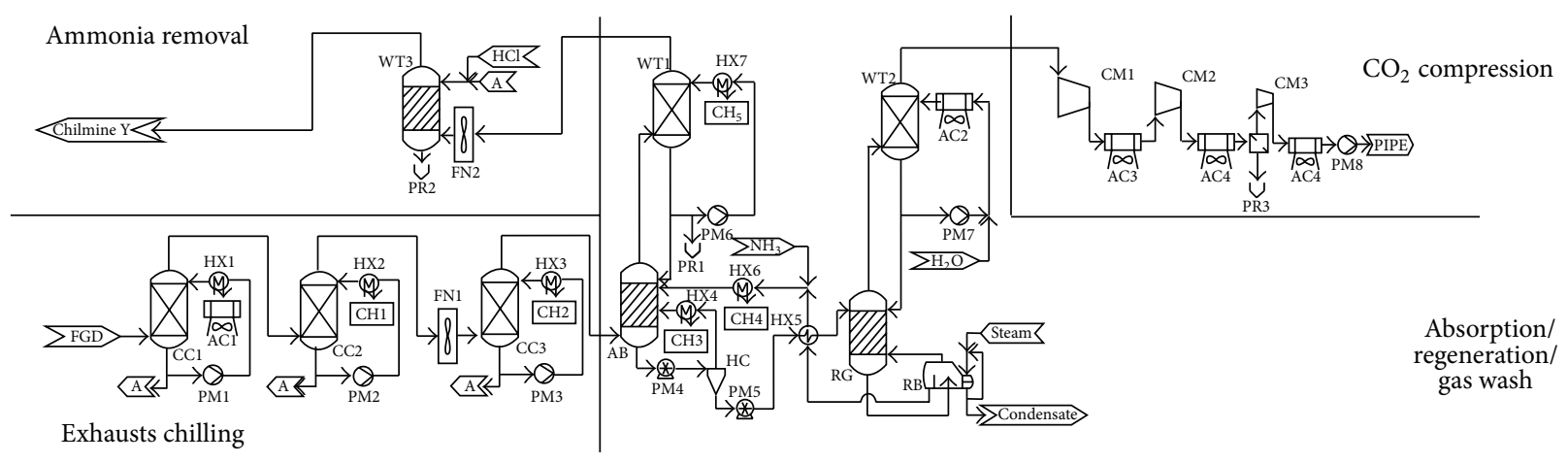

FIGURE 6: Schematic layout of $\mathrm{CO}_{2}$ separation block based on the chilled ammonia process [92].

TABLE 3: Adsorption capacity of chemical adsorbents for post-combustion $\mathrm{CO}_{2}$.

\begin{tabular}{|c|c|c|c|c|c|c|}
\hline Sorbent & $\begin{array}{c}\text { Operating } \\
\text { temperature } \\
(\mathrm{K})\end{array}$ & $\begin{array}{l}\text { Operating } \\
\text { pressure } \\
(\mathrm{kPa})\end{array}$ & $\begin{array}{c}\mathrm{CO}_{2} \text { capture } \\
\text { capacity (mol } \\
\mathrm{CO}_{2} / \mathrm{kg} \text { sorbent) }\end{array}$ & $\begin{array}{l}\text { Regeneration } \\
\text { cycles, } n\end{array}$ & $\begin{array}{c}\mathrm{CO}_{2} \text { capture } \\
\text { capacity remained } \\
\text { after } n \text { cycles }(\%)\end{array}$ & Reference \\
\hline Mesoporous (MgO) & 298 & 101 & 1.8 & 3 & 100 & {$[93]$} \\
\hline $\mathrm{CaO}$ nanopods & 873 & 101 & 17.5 & 50 & 61.1 & {$[94]$} \\
\hline $\mathrm{CaO}$ derived from nanosized $\mathrm{CaCO}_{3}$ & 923 & 101 & 16.7 & 100 & 22.2 & {$[93]$} \\
\hline $\mathrm{CaO}-\mathrm{MgAl}_{2} \mathrm{O}_{4}$ (spinel nanoparticles) & 923 & 101 & 9.1 & 65 & 84.6 & {$[93]$} \\
\hline Nano $\mathrm{CaO} / \mathrm{Al}_{2} \mathrm{O}_{3}$ & 923 & 101 & 6.0 & 15 & 61.7 & {$[93]$} \\
\hline Lithium silicate nanoparticles & 883 & 101 & 5.77 & n.a. & n.a. & [93] \\
\hline Nanocrystalline $\mathrm{Li}_{2} \mathrm{ZrO}_{3}$ particles & 843 & 101 & 6.1 & 8 & 100 & [93] \\
\hline $\mathrm{CaO} / \mathrm{Al}_{2} \mathrm{O}_{3}$ & 923 & 101 & 6.02 & n.a. & n.a. & [93] \\
\hline Lithium silicate & 993 & n.a. & 8.18 & n.a. & n.a. & [17] \\
\hline Lithium zirconate & 673 & 100 & 5.0 & n.a. & n.a. & [93] \\
\hline Lithium orthosilicate & 873 & 100 & 6.13 & n.a. & n.a. & [93] \\
\hline Calcium oxide & 873 & 100 & 17.3 & n.a. & n.a. & [93] \\
\hline Magnesium hydroxide & 473 & 1034 & 3.0 & n.a. & n.a. & [93] \\
\hline Mesoporous magnesium oxide & 373 & 100 & 2.27 & n.a. & n.a. & {$[93]$} \\
\hline Lithium Silicate nano particles & 873 & 101 & 5 & n.a. & n.a. & {$[95]$} \\
\hline HTI-HNa & 573 & 134 & 1.109 & 50 & 93.3 & [93] \\
\hline
\end{tabular}

The reaction of $\mathrm{CO}_{2}$ adsorption with $\mathrm{Li}_{2} \mathrm{ZrO}_{3}$ is reversible in the temperature range of $723-863 \mathrm{~K}$. The capacity of lithium silicate $(8.2 \mathrm{moL} \mathrm{CO} / \mathrm{kg}$ sorbent at $993 \mathrm{~K})$ is larger than that of lithium zirconate $(4.85 \mathrm{moL} / \mathrm{kg}$ sorbent $)$ [17].

Hydrotalcite (HT) contains layered structure with positively charged cations balanced by negatively charged anions [97, 98]. Adsorption and final capacity of different adsorption/desorption cycles are listed in Table 3.

One way for improving $\mathrm{CO}_{2}$ adsorption efficiency is application of nanomaterials. Different nano-materials can be used for $\mathrm{CO}_{2}$ separation (Table 3). However, nanomaterials always have high production cost with complicated synthesis process such as carbon nanotubes and graphite nanoplatelets $[99,100]$.

The main disadvantage of chemical adsorbents is difficult regeneration process, and application of these adsorbents needs more studies for finding new adsorbents [88, 95].

2.2.2. Physical Adsorption. Physisorption, also called physical adsorption, is a process in which the electronic structure of the atom or molecule is barely perturbed upon adsorption. If the $\mathrm{CO}_{2}$ adsorption capacity of solid adsorbents reaches $3 \mathrm{mmoL} / \mathrm{g}$, the required energy for adsorption will be less than 30-50\% energy for absorption with optimum aqueous MEA [101]. The major physical adsorbents suggested for $\mathrm{CO}_{2}$ adsorption include activated carbons and inorganic porous materials such as zeolites $[102,103]$. The adsorption capacities of various physical adsorbents are summarized in Table 4.

Coal is one of the adsorbents being suggested for $\mathrm{CO}_{2}$ separation. The total amount of $\mathrm{CO}_{2}$ that can be adsorbed in coal depends on its porosity, ash, and affinity for this molecule [111, 112]. Sakurovs et al. [113] showed that the ratio of maximum sorption capacity between $\mathrm{CO}_{2}$ and methane decreases with increasing carbon content. The average $\mathrm{CO}_{2} / \mathrm{CH}_{4}$ sorption ratio is higher for moistureequilibrated coal and decreases with increasing coal rank (1.4 for high rank coals to 2.2 for low rank coals) [114-116].

Activated carbon (AC) has a number of attractive characteristics, such as its high adsorption capacity, high hydrophobicity, low cost, and low energy requirement for regeneration 
TABLE 4: Adsorption capacity of physical adsorbents for post-combustion $\mathrm{CO}_{2}$.

\begin{tabular}{|c|c|c|c|c|c|c|}
\hline Sorbent & $\begin{array}{c}\text { Operating } \\
\text { temperature } \\
(\mathrm{K})\end{array}$ & $\begin{array}{c}\text { Operating } \\
\text { pressure } \\
(\mathrm{kPa})\end{array}$ & $\begin{array}{c}\mathrm{CO}_{2} \text { capture } \\
\text { capacity (mol } \\
\mathrm{CO}_{2} / \mathrm{kg} \text { sorbent) }\end{array}$ & $\begin{array}{l}\text { Regeneration } \\
\text { cycles, } n\end{array}$ & $\begin{array}{c}\mathrm{CO}_{2} \text { capture capacity } \\
\text { remained after } n \\
\text { cycles }(\%)\end{array}$ & Reference \\
\hline Activated carbon & 303 & 110 & 1.58 & n.a. & n.a. & {$[93]$} \\
\hline $\mathrm{AC}(4 \% \mathrm{KOH})$ & 303 & 30 & 0.55 & n.a. & n.a. & {$[93]$} \\
\hline $\mathrm{AC}(\mathrm{EDA}+\mathrm{EtOH})$ & 303 & 30 & 0.53 & n.a. & n.a. & {$[93]$} \\
\hline $\mathrm{AC}(4 \% \mathrm{KOH}+\mathrm{EDA}+\mathrm{EtOH})$ & 303 & 30 & 0.64 & n.a. & n.a. & {$[45,70,79]$} \\
\hline $\mathrm{NiO}-\mathrm{ACs}$ & 298 & 101 & 2.227 & n.a. & n.a. & {$[104]$} \\
\hline $13 X$ & 393 & 15.198 & 0.7 & n.a. & n.a. & {$[105]$} \\
\hline $5 \mathrm{~A}$ & 393 & 15.198 & 0.38 & n.a. & n.a. & {$[105,106]$} \\
\hline $4 \mathrm{~A}$ & 393 & 15.198 & 0.5 & n.a. & n.a. & {$[105]$} \\
\hline WEG-592 & 393 & 15.198 & 0.6 & n.a. & n.a. & {$[105]$} \\
\hline APG-II & 393 & 15.198 & 0.38 & n.a. & n.a. & {$[105]$} \\
\hline $\mathrm{Na}-\mathrm{Y}$ & 273 & 10.132 & 4.9 & n.a. & n.a. & {$[105]$} \\
\hline $\mathrm{Na}-\mathrm{X}$ & 373 & 101.32 & 1.24 & 2 & n.a. & {$[105]$} \\
\hline $\mathrm{NaKA}$ & 373 & 101.32 & 3.88 & - & n.a. & {$[105]$} \\
\hline $\mathrm{NaX}-\mathrm{h}$ & 323 & 101.32 & 2.52 & 2 & n.a. & {$[105]$} \\
\hline $\mathrm{NaX}-\mathrm{h}$ & 373 & 101.32 & 1.37 & 2 & n.a. & {$[105]$} \\
\hline $\mathrm{Na}-\mathrm{X}-\mathrm{c}$ & 323 & 101.32 & 2.14 & 2 & n.a. & {$[105]$} \\
\hline $\mathrm{Na}-\mathrm{X}-\mathrm{c}$ & 373 & 101.32 & 1.41 & 2 & n.a. & {$[105]$} \\
\hline Cs-X-h & 323 & 101.32 & 2.42 & 2 & n.a. & {$[105]$} \\
\hline Cs-X-h & 373 & 101.32 & 1.48 & 2 & n.a. & {$[105]$} \\
\hline Cs-X-c & 323 & 101.32 & 1.76 & 2 & n.a. & {$[105]$} \\
\hline Cs-X-c & 373 & 101.32 & 1.15 & n.a. & n.a. & {$[105]$} \\
\hline MCM-41 & 298 & 100 & 0.62 & n.a. & n.a. & {$[93]$} \\
\hline MCM-41 (DEA) & 348 & 100 & 1.26 & n.a. & n.a. & {$[93]$} \\
\hline MCM-41 (50\% PEI) & 348 & 100 & 2.52 & n.a. & n.a. & {$[93]$} \\
\hline Activated carbon & 303 & 30 & 0.35 & n.a. & n.a. & {$[93]$} \\
\hline $\begin{array}{l}\text { MCM-41 (50\% PEI) "molecular } \\
\text { basket" }\end{array}$ & 348 & 100 & 2.95 & n.a. & n.a. & [93] \\
\hline PE-MCM-41 & 298 & 100 & 0.50 & n.a. & n.a. & {$[93]$} \\
\hline PE-MCM-41 (TRI) & 298 & 100 & 2.85 & n.a. & n.a. & {$[93]$} \\
\hline PE-MCM-41 (DEA) & 348 & 100 & 2.36 & n.a. & n.a. & {$[93]$} \\
\hline MCM-48 & 298 & 100 & 0.033 & n.a. & n.a. & {$[93]$} \\
\hline MCM-48 (APTS) & 298 & 100 & 0.639 & n.a. & n.a. & {$[93]$} \\
\hline MCM-41 & 298 & 100 & 0.62 & n.a. & n.a. & {$[93]$} \\
\hline $\begin{array}{l}\text { Molecular basket' } \\
\text { MCM-41 (50\% PEI) }\end{array}$ & 348 & 100 & 2.5 & 8 & 96.0 & {$[93]$} \\
\hline PE-MCM-41 (TRI) & 298 & 100 & 1.8 & 10 & 94.4 & {$[93]$} \\
\hline PE-MCM-41 (DEA) & 298 & 100 & 2.9 & 7 & 96.6 & {$[93]$} \\
\hline MWNT & 303 & 101 & 1.7 & 20 & n.a. & {$[4,93]$} \\
\hline Unmodified $\left[\left(\mathrm{Cu}_{3}(\mathrm{btc})_{2}\right]^{*}\right.$ & 298 & 1818 & 6.7 & n.a. & n.a. & {$[101]$} \\
\hline CNT@ $\left(\mathrm{Cu}_{3}(\mathrm{btc})_{2}\right)$ & 298 & 1818 & 13.52 & n.a. & n.a. & {$[101]$} \\
\hline MIL-101** & 298 & 1010 & 0.84 & n.a. & n.a. & {$[101]$} \\
\hline MWCNT@MIL-101 & 298 & 1010 & 1.35 & n.a. & n.a. & {$[101]$} \\
\hline MOF-2 & 298 & 4545 & 3.20 & n.a. & n.a. & {$[107]$} \\
\hline MOF-177 & 298 & 4545 & 33.5 & n.a. & n.a. & {$[107]$} \\
\hline Zr-MOFs & 273 & 988 & 8.1 & n.a. & n.a. & {$[107]$} \\
\hline Ca-Al LDH with $\mathrm{ClO}_{4}^{-}$ & 406 & 1 & 3.55 & n.a. & n.a. & {$[108]$} \\
\hline
\end{tabular}


TABLE 4: Continued.

\begin{tabular}{|c|c|c|c|c|c|c|}
\hline Sorbent & $\begin{array}{c}\text { Operating } \\
\text { temperature } \\
(\mathrm{K})\end{array}$ & $\begin{array}{l}\text { Operating } \\
\text { pressure } \\
(\mathrm{kPa})\end{array}$ & $\begin{array}{c}\mathrm{CO}_{2} \text { capture } \\
\text { capacity (mol } \\
\mathrm{CO}_{2} / \mathrm{kg} \text { sorbent) }\end{array}$ & $\begin{array}{l}\text { Regeneration } \\
\text { cycles, } n\end{array}$ & $\begin{array}{c}\mathrm{CO}_{2} \text { capture capacity } \\
\text { remained after } n \\
\text { cycles }(\%)\end{array}$ & Reference \\
\hline Pd-GNP nanocomposite & 298 & 1111 & 5.1 & n.a. & n.a. & [109] \\
\hline f-GNP & 298 & 1111 & 4.3 & n.a. & n.a. & [109] \\
\hline Pd-GNP nanocomposite & 298 & 1111 & 4.5 & n.a. & n.a. & [109] \\
\hline f-GNP & 298 & 1111 & 3.8 & n.a. & n.a. & [109] \\
\hline Pd-GNP nanocomposite & 298 & 1111 & 4.1 & n.a. & n.a. & [109] \\
\hline f-GNP & 298 & 1111 & 3.3 & n.a. & n.a. & [109] \\
\hline $\begin{array}{l}\text { Ceria-based oxides doped with 5\% } \\
\text { gallium (III) }\end{array}$ & 298 & 101 & 0.282 & n.a. & n.a. & [110] \\
\hline $\begin{array}{l}\text { Amine modified layered double } \\
\text { hydroxides (LDHs) }\end{array}$ & $298-353$ & 101 & $0.74-1.75$ & n.a. & n.a. & [108] \\
\hline
\end{tabular}

${ }^{*} \mathrm{Cu}_{3}(\text { btc })_{2}$; btc: 1,3,5-benzene-tricarboxylate.

${ }^{* *}$ MIL-101 or $\mathrm{Cr}_{3}(\mathrm{~F}, \mathrm{OH})\left(\mathrm{H}_{2} \mathrm{O}\right)_{2} \mathrm{O}\left[\left(\mathrm{O}_{2} \mathrm{C}\right) \mathrm{C}_{6} \mathrm{H}_{4}\left(\mathrm{CO}_{2}\right)\right]_{3} \cdot n \mathrm{H}_{2} \mathrm{O}(n \approx 25)$ is one of the metal organic frameworks with Lewis acid sites that can be activated by removal of guest water molecules.

[117-119]. Activated carbons are inexpensive, insensitive to moisture, and easy for regeneration. These adsorbents have well developed micro- and mesopore structures that are suitable for high $\mathrm{CO}_{2}$ adsorption capacity at ambient pressure [120-122].

However, activated carbon $\mathrm{CO}_{2} / \mathrm{N}_{2}$ selectivities (ca. 10) are relatively low; zeolitic materials offer $\mathrm{CO}_{2} / \mathrm{N}_{2}$ selectivities 5-10 times greater than those of carbonaceous materials. The adsorption capacity and selectivity of zeolites are largely affected by their size, porous diameter, charge density, and chemical composition of cations in their porous structures. The average value of heat adsorption on zeolites $(36 \mathrm{~kJ} / \mathrm{moL})$ is larger than for activated carbon $(30 \mathrm{~kJ} / \mathrm{moL})$, confirming the mentioned affirmation. Moreover, activated carbon can be regenerated easily and completely. Also its capacity did not decay after 10 consecutive processes cycles [122-124].

Due to the increase in cost of raw materials, growing research interest has been focused on producing AC from agricultural wastes. Some of the agricultural wastes include the shells and stones of fruits, wastes resulting from the production of cereals, bagasse, and coir pith [100]. Rosas et al. [125] prepared hemp-derived AC monolith by phosphoric acid activation. The activated carbons from hemp stem are microporous materials and therefore suitable ones for hydrogen storage and $\mathrm{CO}_{2}$ capture [126].

Siriwardane et al. [127] studied $\mathrm{CO}_{2}$ adsorption on the molecular sieve 13X, 4A and activated carbon. The molecular sieve $13 \mathrm{X}$ showed better $\mathrm{CO}_{2}$ separation than molecular sieve $4 \mathrm{~A}$. At lower pressures ( $<50 \mathrm{psi})$, activated carbon had a lower $\mathrm{CO}_{2}$ separation than the molecular sieves, but adsorption was higher for activated carbon than molecular sieves at higher pressures [127, 128].

Liu et al. [129] indicated that zeolite 5A has higher volumetric capacities and less severe heat effect of the zeolite 13X. Chabazite zeolites were prepared and exchanged with alkali cations: $\mathrm{Li}, \mathrm{Na}, \mathrm{K}$ and alkaline-earth cations: $\mathrm{Mg}, \mathrm{Ca}$, $\mathrm{Ba}$. Zhang et al. [130] studied the potential of these zeolites for $\mathrm{CO}_{2}$ separation from flue gas by vacuum swing adsorption. It was found that $\mathrm{NaCHA}$ and $\mathrm{CaCHA}$ hold comparative advantages for high temperature $\mathrm{CO}_{2}$ separation whilst $\mathrm{NaX}$ showed superior performance at relatively low temperatures [130]. In physical adsorption, the size and volume of the pores are important. Micropores are defined as pores, $2 \mathrm{~nm}$ in size, mesopores between 2 and $50 \mathrm{~nm}$, and macropores, $50 \mathrm{~nm}$ in size. The micropores make better selective adsorption of $\mathrm{CO}_{2}$ over $\mathrm{CH}_{4}[131,132]$.

Carbon nanotubes (CNTs) are the most famous among nano-hollow structured materials and their dimension ranges from 1 to $10 \mathrm{~nm}$ in diameter and from 200 to $500 \mathrm{~nm}$ in length [133]. Cinke et al. [134] indicated that purified single-walled carbon nanotubes (SWNTs) adsorbed $\mathrm{CO}_{2}$ better than unpurified SWNT. In addition, multiwalled carbon nanotubes (MWNTs) showed stability for 20 cycles of adsorption and regeneration [135].

More recently, nanosystems researchers have synthesized and screened a large number of zeolitic-type materials known as zeolitic imidazolate frameworks (ZIFs). $\mathrm{CO}_{2}$ capacities of the ZIFs are high, and selectivity against $\mathrm{CO}$ and $\mathrm{N}_{2}$ is good $[136,137]$. The results of researchers (Burchell and Judkins [138], Dave et al. [28], and Yong et al. [139]) indicated that the $\mathrm{CO}_{2}$ adsorption efficiency of the honeycomb monolith is twice than activated carbon and 1.5 times greater than ZIF material [29]. Results of Kimber et al. [140] showed that $\mathrm{CO}_{2}$ selectivity of honeycomb monolithic composite decreased with increasing in burn-off.

Graphite nanoplatelets (GNP) were prepared by acid intercalation followed by thermal exfoliation of natural graphite. Functionalized graphite nanoplatelets (f-GNP) were prepared by further treatment of GNP in acidic medium. Palladium (Pd) nanoparticles were decorated over f-GNP surface by chemical method [109, 141, 142]. Adsorption capacity of this adsorbent is presented in Table 4.

The presence of several impurity gases $\left(\mathrm{SO}_{x} / \mathrm{NO}_{x} / \mathrm{H}_{2} \mathrm{O}\right)$ greatly complicates the $\mathrm{CO}_{2}$ separation processes. Therefore, conventional adsorption-based $\mathrm{CO}_{2}$ separation processes rely on using a pretreatment stage to remove water, $\mathrm{SO}_{x}$, and $\mathrm{NO}_{x}$, which adds considerably to the overall cost. Also this prelayer can be used before the amine absorption column 
[143, 144]. Deng et al. [145] showed that the adsorption capacities follows the order $\mathrm{SO}_{2}>\mathrm{CO}_{2}>\mathrm{NO}>\mathrm{N}_{2}$ on both zeolites (5A and 13X). Comparing two different adsorbents, the better separation efficiency can be achieved by $5 \mathrm{~A}$ zeolite [145].

Zhang et al. [130] focused on the effect of water vapour on the pressure/vacuum swing adsorption process. The selected adsorbents in this study were CDX (an alumina/zeolite blend), alumina, and $13 \mathrm{X}$ zeolite as these adsorbents are either the prelayer for water adsorption or the main $\mathrm{CO}_{2}$ adsorption layer in the packed bed [130].

Metal-organic framework (MOF) materials are crystalline with two- or three-dimensional porous structures that can be synthesised with many of the functional capabilities of zeolites. Several MOFs have been proposed as adsorbents for $\mathrm{CO}_{2}$ separation processes, and among these $\mathrm{Cu}-\mathrm{BTC}$ [polymeric copper (II) benzene-1,3,5-tricarboxylate] has proved to be dedicated with $\mathrm{CO}_{2}$ adsorption performances that are higher than those of typical adsorbents such as $13 \mathrm{X}$ zeolite $[105,107,146,147]$.

The MCM-41 material is one of the mesoporous products which was prepared by the hydrothermal method from mobil composition of matter (MCM) powders. Lu et al. [148] showed that mesoporous silica spherical particles (MSPs) can be synthesized using low-cost $\mathrm{Na}_{2} \mathrm{SiO}_{3}$ thus they can be cost-effective adsorbents for $\mathrm{CO}_{2}$ separation from flue gas $[149,150]$.

Layered double hydroxides (LDHs) have general formula $\left[\mathrm{M}_{1-x}^{\mathrm{II}} \mathrm{M}_{x}^{\mathrm{III}}(\mathrm{OH})_{2}\right]\left[\mathrm{X}_{x / \mathrm{C}}^{g-} \cdot n \mathrm{H}_{2} \mathrm{O}\right]$ with $x$ typically in the range between 0.10 and 0.33 . These materials can be readily and inexpensively synthesized with the desired characteristics for a particular application such as $\mathrm{CO}_{2}$ adsorption $[108,151]$.

2.2.3. Adsorbent Modification. The role of $\mathrm{CO}_{2}$ as a weak Lewis acid is well established. Because of the nature of $\mathrm{CO}_{2}$, the surface of the physical adsorbents can be modified by adding basic groups, such as amine groups and metal oxides to improve $\mathrm{CO}_{2}$ adsorption capacity or selectivity [152-154]. Three different methods for the production of these adsorbents were investigated: activation with $\mathrm{CO}_{2}$, heat treatment with ammonia gas (amination and ammoxidation), and heat treatment with polyethylenimine (PEI). However, it has been suggested that amine modification can produce better and cheaper $\mathrm{CO}_{2}$ adsorbents $[24,104,155,156]$.

$\mathrm{Xu}$ et al. $[157,158]$ designed selective "molecular basket" by grafting polyethylenimine (PEI) uniformly on MCM-41. $\mathrm{CO}_{2}$ adsorption capacity of the adsorbent was 24 times higher than MCM-41 and 2 times higher than PEI [93]. The addition of ammonium hydroxide resulted in the $\mathrm{Zr}-\mathrm{MOF}$ with a slight lower adsorption of $\mathrm{CO}_{2}$ and $\mathrm{CH}_{4}$; however, the selectivity of $\mathrm{CO}_{2} / \mathrm{CH}_{4}$ is significantly enhanced $[159,160]$. Results of Abid et al. [107] showed that the selectivity of $\mathrm{CO}_{2} / \mathrm{CH}_{4}$ on $\mathrm{Zr}-\mathrm{MOF}$ is between 2.2 and 3.8, while for $\mathrm{Zr}-\mathrm{MOF}-\mathrm{NH}_{4}$ selectivity is between 2.6 and 4.3 .

A nitrogen-rich carbon with a hierarchical micro-mesopore structure exhibited a high $\mathrm{CO}_{2}$ adsorption capacity $(141 \mathrm{mg} / \mathrm{g}$ at $298 \mathrm{~K}, 1 \mathrm{~atm})$, excellent separation efficiency $\left(\mathrm{CO}_{2} / \mathrm{N}_{2}\right.$ selectivity is ca. 32$)$, and excellent stability [161].
Plaza et al. [162] results showed that $\mathrm{CO}_{2}$ adsorption capacity of the DETA-impregnated alumina $(\geq 2.3 \mathrm{mmoL} / \mathrm{g})$ exhibited is the highest.

Amine modified layered double hydroxides (LDHs) have been prepared by several different methods. Park et al. [163] used dodecyl sulfate (DS) intercalated LDH as precursor and added (3-aminopropyl) triethoxysilane (APTS) together with N-cetyl-N,N,N-trimethylammonium bromide (CTAB) [164]. The highest adsorption capacity of amine modified LDHs for $\mathrm{CO}_{2}$ was achieved at $1.75 \mathrm{mmoL} / \mathrm{g}$ by $\mathrm{MgAl} \mathrm{N} 3$ at $353 \mathrm{~K}$ and 1 bar. According to data in Table 4, this adsorbent has high $\mathrm{CO}_{2}$ capacity at high temperature; therefore, this adsorbent is suitable for post-combustion $\mathrm{CO}_{2}$ capture [108].

Wang et al. [114] reported that porous carbons with welldeveloped pore structures were directly prepared from a weak acid cation exchange resin (CER) by the carbonization of a mixture with $\mathrm{Mg}$ acetate in different ratios [108]. The main parameters of this adsorbent (such as $\mathrm{CO}_{2}$ capacity) are indicated in Table 4.

Shafeeyan et al. [165] prepared different adsorbents based on the central composite design (CCD) with three independent variables (i.e., amination temperature, amination time, and the use of preheat treated (HTA) or preoxidized (OXA) sorbent as the starting material). They demonstrated that the optimum condition for obtaining an efficient $\mathrm{CO}_{2}$ adsorbent is using a preoxidized sorbent and amination at $698 \mathrm{~K}$ for $2.1 \mathrm{~h}$ [165].

Table 4 compares $\mathrm{CO}_{2}$ adsorption capacities and stability of different absorbents, which were studied for postcombustion $\mathrm{CO}_{2}$ capture.

2.2.4. Different Cycles for $\mathrm{CO}_{2}$ Adsorption. Five different regeneration strategies were demonstrated in a single-bed $\mathrm{CO}_{2}$ adsorption unit: pressure swing adsorption (PSA), temperature swing adsorption (TSA), vacuum swing adsorption (VSA), electric swing adsorption (ESA), and a combination of vacuum and temperature swing adsorption (VTSA). The difference between these technologies is based on the strategy for regeneration of adsorbent after the adsorption step (Figure 7). In PSA applications, the pressure of the bed is reduced. VSA is preferred to the special PSA application where the desorption pressure is below atmospheric, whereas in TSA, the temperature is raised while pressure is maintained approximately constant, and in ESA the solid is heated by the Joule effect [166-169].

For the single-bed cycle configurations, the productivity and $\mathrm{CO}_{2}$ recovery followed the sequence:

$$
\mathrm{ESA}<\mathrm{TSA}<\mathrm{PSA}<\mathrm{VSA}<\mathrm{VTSA} .
$$

The performances of PSA, TSA, VSA, VTSA, and ESA processes for $\mathrm{CO}_{2}$ separation are reported in Table 5. Since application of adsorption process for $\mathrm{CO}_{2}$ capture in industrial scale is very important, in recent years some researches have been focused on this area; for example, Lucas et al. [170] studied the scale-up $\mathrm{CO}_{2}$ adsorption with activated carbon.

2.3. Cryogenic Distillation. Cryogenic method utilized low temperatures for condensation, separation, and purification 


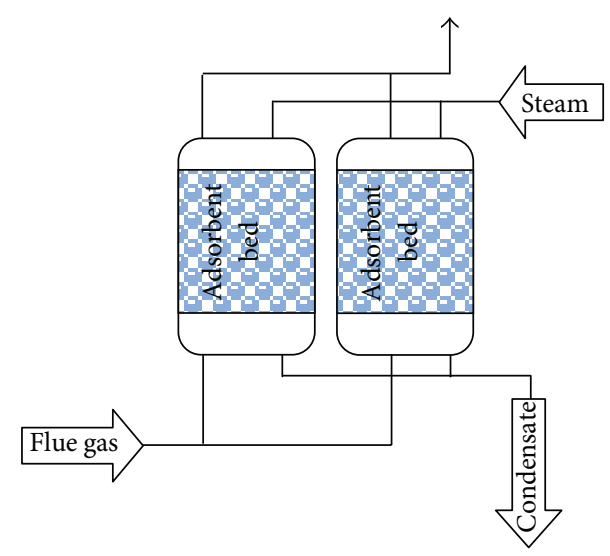

(a)

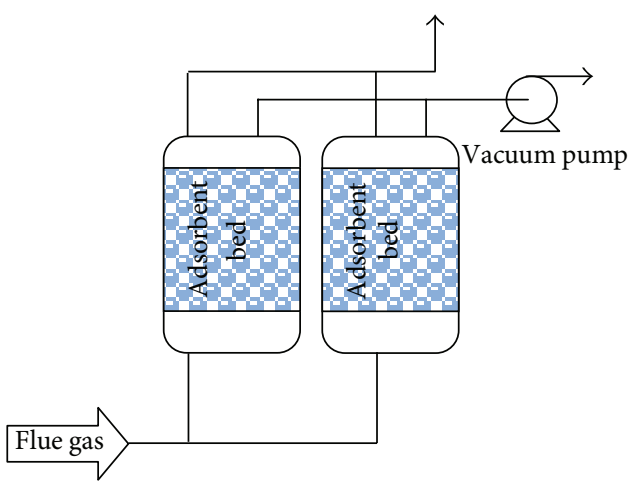

(c)

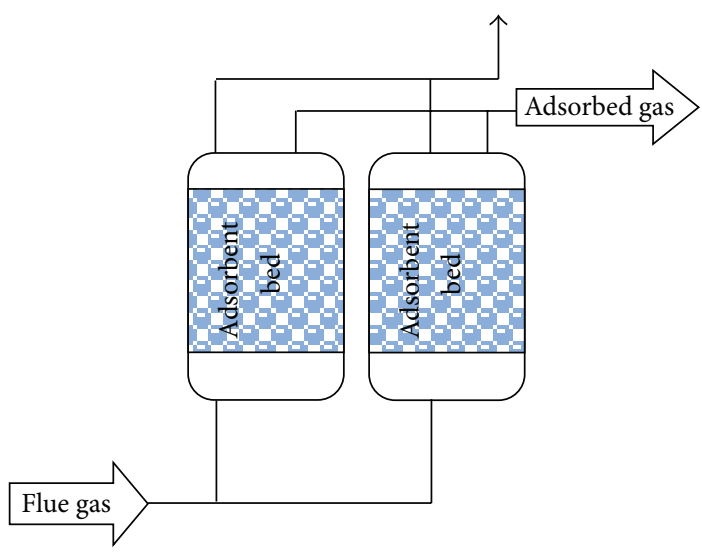

(b)

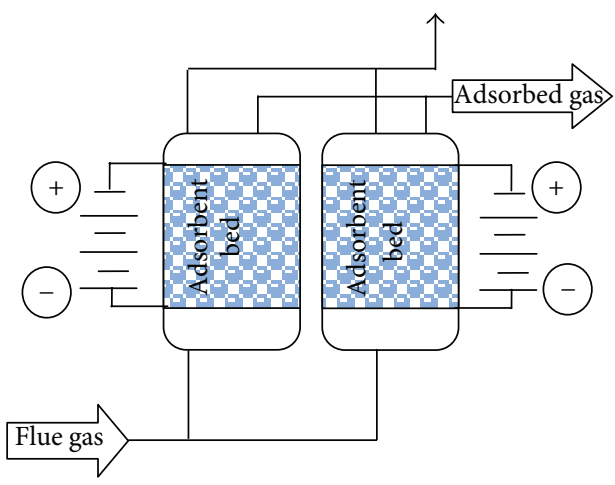

(d)

FIGURE 7: Schematic diagrams of various adsorption cycles, (a) TSA, (b) PSA, (c) VSA, and (d) ESA; thin lines indicated operation streams in regenerated step.

TABlE 5: Comparison between several adsorption cycles for $\mathrm{CO}_{2}$ separation process [166].

\begin{tabular}{lccc}
\hline Process & $\begin{array}{c}\mathrm{CO}_{2} \text { feed molar fraction } \\
(\%) \text { (other gases present) }\end{array}$ & $\begin{array}{c}\mathrm{CO}_{2} \\
\text { purity }(\%)\end{array}$ & $\begin{array}{c}\mathrm{CO}_{2} \\
\text { recovery }(\%)\end{array}$ \\
\hline PSA & $13\left(\mathrm{O}_{2}\right)$ & 99.5 & 69 \\
TSA & 10 & 95 & 81 \\
TSA & 17 & n.a. & 40 \\
ESA & 10 & 23.33 & 92.57 \\
VSA & 15 & 90 & 90 \\
VSA & 17 & n.a. & 87 \\
3-bed VSA & 12 & $90-95$ & $60-70$ \\
PSA/VSA & 20 & $58-63$ & $70-75$ \\
PSA/VSA & $15\left(\mathrm{H}_{2} \mathrm{O}\right)$ & 59 & 87 \\
VPSA & 17 & $99.5-99.8$ & $34-69$ \\
VPSA & $16\left(\mathrm{O}_{2}\right)$ & 99 & $53-70$ \\
PTSA & 10 & 99 & 90 \\
2-bed-2-step & & 18 & 90 \\
PSA & n.a. & & \\
VTSA & 17 & n.a. & 97 \\
\hline
\end{tabular}

of $\mathrm{CO}_{2}$ from flue gases (freezing point of pure $\mathrm{CO}_{2}$ is $195.5 \mathrm{~K}$ at atmospheric pressure). Therefore, under the cryogenic separation process, the components can be separated by a series of compression, cooling, and expansion steps. It enables direct production of liquid $\mathrm{CO}_{2}$ that can be stored or sequestered at high pressure via liquid pumping [171-173].

The advantages of this technology can be summarized as follows $[6,8,174]$.

(1) Liquid $\mathrm{CO}_{2}$ is directly produced, thus making it relatively easy to store or send for enhanced oil recovery.

(2) This technology is relatively straightforward, involving no solvents or other components.

(3) The cryogenic separation can be easy scaled-up to industrial-scale utilization.

The major disadvantages of this process are the large amount of energy required to provide the refrigeration and the $\mathrm{CO}_{2}$ solidification under a low temperature, which causes several operational problems [176-178]. Therefore, more studies are required for reducing the cost of cryogenic separation.

Clodic et al. [179] indicated that the energy requirement for cryogenic process was in the range of 541-1119 kJ/kg CO $\mathrm{CO}_{2}$. Zanganeh et al. [6] have constructed a pilot-scale $\mathrm{CO}_{2}$ capture and compression unit $\left(\mathrm{CO}_{2} \mathrm{CCU}\right)$ that can separate $\mathrm{CO}_{2}$ as liquid phase from the flue gas of oxy-fuel combustion. Their results showed that cryogenic is the most cost effective when 


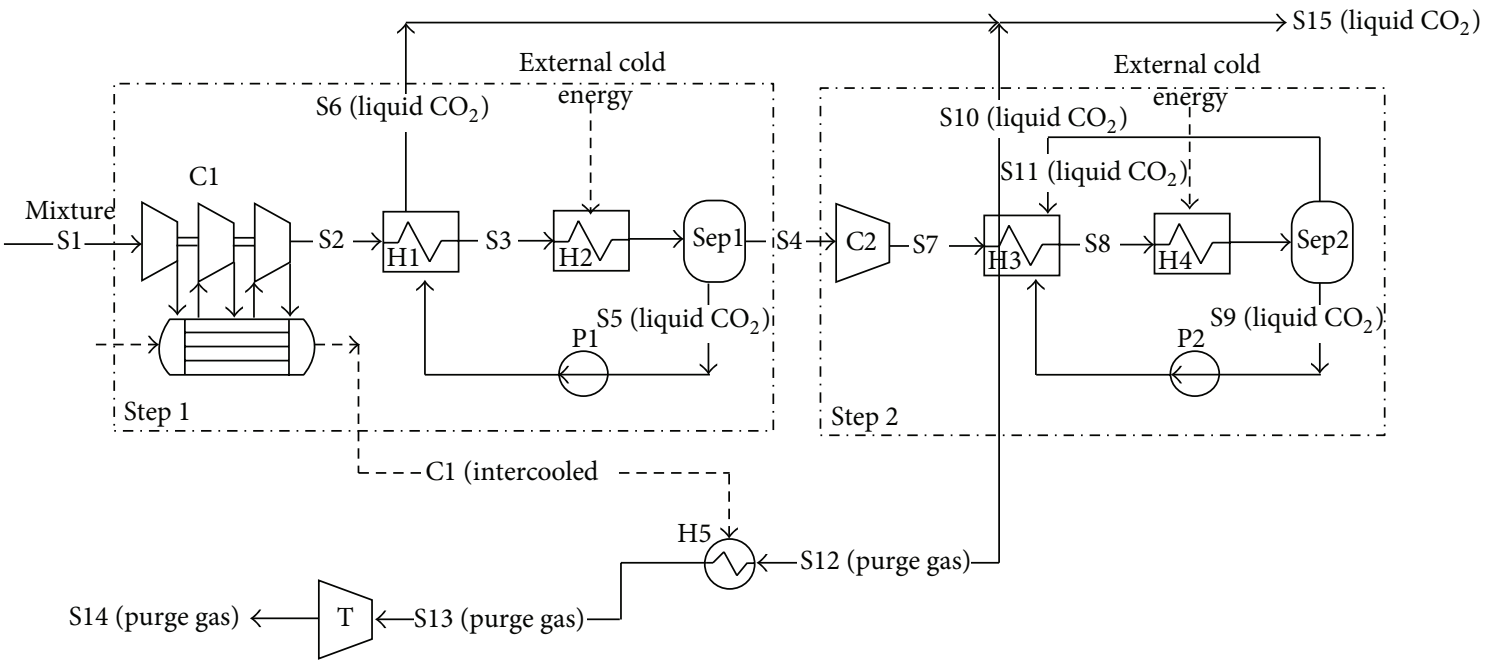

Figure 8: Novel $\mathrm{CO}_{2}$ cryogenic liquefaction and separation system [175].

the feed gas is available at high pressure. Therefore, cryogenic is not suitable for post-combustion and it is well effective for separation stream with high $\mathrm{CO}_{2}$ concentration such as oxyfuel combustion. Amann et al. [180] reported that conversion of $\mathrm{O}_{2} / \mathrm{CO}_{2}$ cycle was more efficient than amine scrubbing but more difficult to implement because of the specific gas turbine.

$\mathrm{Xu}$ et al. [175] studied a novel $\mathrm{CO}_{2}$ cryogenic liquefaction and separation system (Figure 8 ). In this system, two-stage compression, two-stage refrigeration, two-stage separation, and sufficient recovery of cryogenic energy were adopted. The energy consumption for $\mathrm{CO}_{2}$ recovery is only $0.395 \mathrm{MJ} / \mathrm{kg}$ $\mathrm{CO}_{2}$. Furthermore, this $\mathrm{CO}_{2}$ cryogenic separation system is more suitable for gas mixtures with high initial pressure and high $\mathrm{CO}_{2}$ concentration [175].

Song et al. [181] developed a novel cryogenic $\mathrm{CO}_{2}$ capture system based on Stirling coolers (SC). The operation of Stirling cooler contains four processes: isothermal expansion, refrigeration under a constant volume, isothermal compression, and heating under a constant volume condition. This novel cryogenic system can condense and separate $\mathrm{H}_{2} \mathrm{O}$ and $\mathrm{CO}_{2}$ from flue gas. Their results showed that under the optimal temperature and flow rate, $\mathrm{CO}_{2}$ recovery of the cryogenic process can reach $96 \%$ with $1.5 \mathrm{MJ} / \mathrm{kg} \mathrm{CO} 2$ energy consumption.

Tuinier et al. [182] exploited a novel cryogenic $\mathrm{CO}_{2}$ capture process using dynamically operated packed beds (Figure 9). By the developed process, above $99 \%$ of $\mathrm{CO}_{2}$ could be recovered from a flue gas containing 10 vol. $\% \mathrm{CO}_{2}$ and 1 vol. $\% \mathrm{H}_{2} \mathrm{O}$ with $1.8 \mathrm{MJ} / \mathrm{kg} \mathrm{CO}_{2}$ energy consumption [181].

Chiesa et al. [183] proposed an advanced cycle that a molten carbonate fuel cell (MCFC) was used to separate the $\mathrm{CO}_{2}$ from the gas turbine exhaust of a natural gas fired combined cycle power plant. In this cycle, gas turbine flue gases actually are used as cathode feeding for MCFC. While $\mathrm{CO}_{2}$ is moved from the cathode to anode side, concentrate $\mathrm{CO}_{2}$ in the anode exhaust. Then the $\mathrm{CO}_{2}$ is concentrated on the anode side of MCFC allowing to easily treat this spent fuel stream in a cryogenic process to split combustible species (routed back to gas turbine combustor) from the $\mathrm{CO}_{2}$ addressed to storage (Figure 10) [183].

2.4. Membrane Separation. The membrane separation method is a continuous, steady-state, clean and simple process, and ideal as an energy-saving method for $\mathrm{CO}_{2}$ recovery. Gas separation using membranes is a pressure-driven process. Due to the low pressure of flue gases, driving force is too low for membrane processes in post-combustion (low pressure and low $\mathrm{CO}_{2}$ concentration). Membrane processes offer increased separation performances when $\mathrm{CO}_{2}$ concentration in the feed mixture increases [184-186].

Membrane separation processes have several advantages over other $\mathrm{CO}_{2}$ separation technologies. The required process equipment is very simple, compact, relatively easy to operate and control, clear process and easy to scale up $[187,188]$.

The energy required for the recovery of $\mathrm{CO}_{2}$ by membrane processes depends on the target purity, flue gas composition, and membrane selectivity for $\mathrm{CO}_{2}$. Howevre membrane processes require too much energy for postcombustion $\mathrm{CO}_{2}$ capture; therefore, low partial pressure of $\mathrm{CO}_{2}$ in the flue gas is a possible disadvantage for the application of membranes. Another disadvantage of membrane process is that the membrane selectivity for the separation of $\mathrm{CO}_{2}$ from $\mathrm{SO}_{x}$ and $\mathrm{NO}_{x}$ is very low. Membrane process is not useful for high flow rate applications [189-191].

Therefore, the useful membrane for post-combustion $\mathrm{CO}_{2}$ capture should have some specification such as $[192,193]$

(i) high $\mathrm{CO}_{2}$ permeability,

(ii) high selectivity for $\mathrm{CO}_{2}$ separatation from flue gases,

(iii) high thermal and chemical stability,

(iv) resistant to plasticisation,

(v) resistant to aging,

(vi) cost effective,

(vii) low production cost for different membrane modules. 


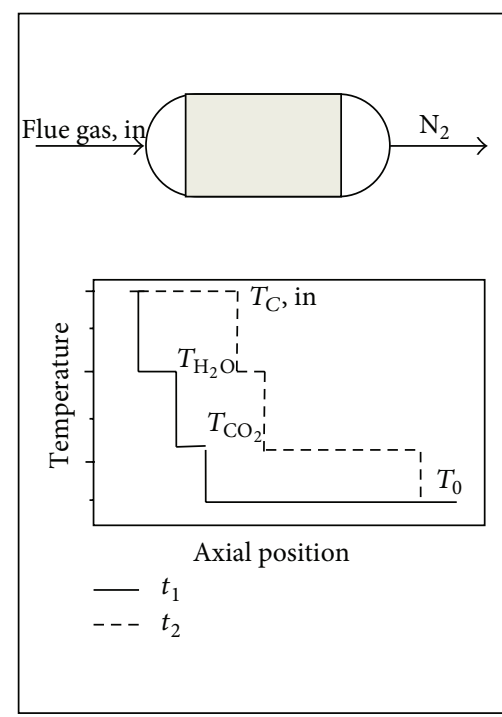

(a)

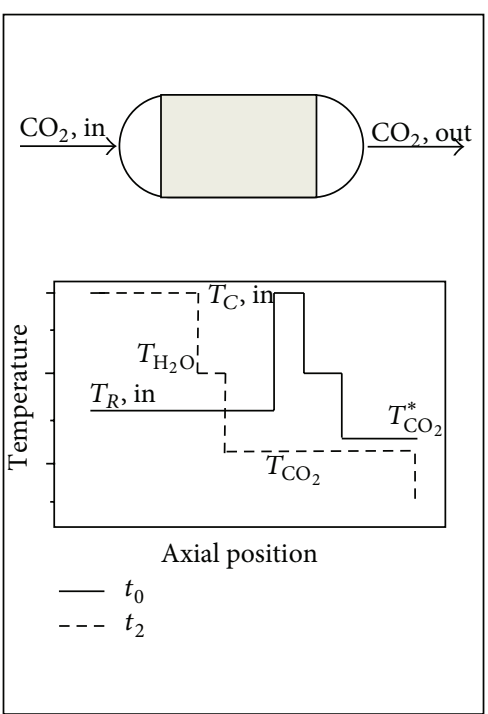

(b)

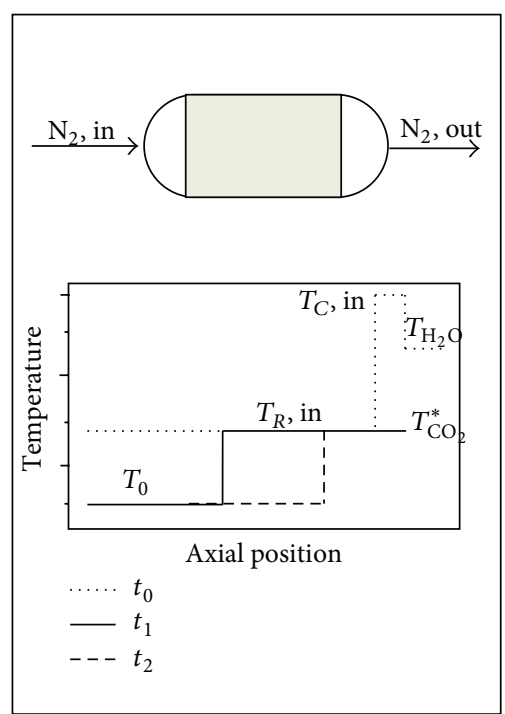

(c)

FIGURE 9: Schematic axial temperature and corresponding mass deposition profiles for the cryogenic; (a) capture, (b) recovery, and (c) cooling cycles [182].

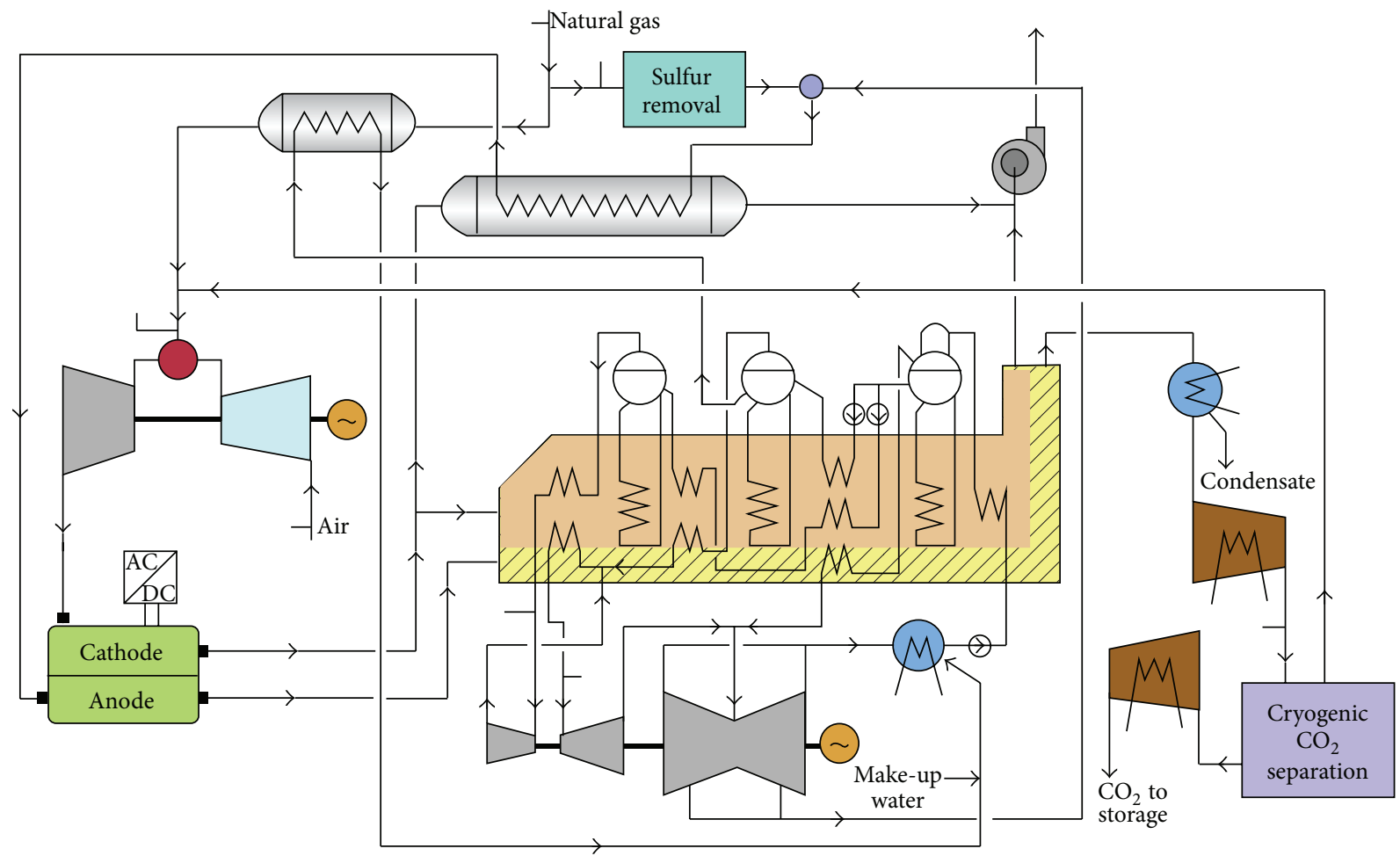

FIGURE 10: Plant layout showing the integration of the MCFC in a combined cycle, with cryogenic $\mathrm{CO}_{2}$ separation after oxygen combustion of the cell an anode exhaust [183].

Many efforts have been made to find new material with suitable properties (Table 6).

Various groups of materials have been already proposed and experimentally investigated for post-combustion $\mathrm{CO}_{2}$ capture with membrane process. By modifying membrane their properties can be improved. For example, when amine functional groups are randomly dispersed in the silica matrix, this membrane can separate $\mathrm{CO}_{2}$ with high selectivity. On the other hand, membrane structure can be modified by adding arginine salts [194-196].

2.4.1. Inorganic Membranes. Based on structure, inorganic membranes can be classified into two categories: porous and 
TABLE 6: Carbon dioxide and nitrogen gas permeability data for different membranes.

\begin{tabular}{|c|c|c|c|c|c|c|}
\hline Name & $\begin{array}{l}\text { Feed pressure } \\
(\mathrm{atm})\end{array}$ & $\begin{array}{c}\text { Temperature } \\
(\mathrm{K})\end{array}$ & $\begin{array}{c}P^{*}\left(\mathrm{CO}_{2}\right) \\
\text { (barrer) }\end{array}$ & $\begin{array}{l}P^{*}\left(\mathrm{~N}_{2}\right) \\
\text { (barrer) }\end{array}$ & $\begin{array}{c}\alpha \\
\left(\mathrm{CO}_{2} / \mathrm{N}_{2}\right) \\
\end{array}$ & Reference \\
\hline \multicolumn{7}{|c|}{ Ion-exchanged zeolites membrane } \\
\hline $\mathrm{Y}(\mathrm{FAU})$ with $\alpha-\mathrm{Al}_{2} \mathrm{O}_{3}$ support & n.a. & 308 & n.a. & n.a. & 139 & [197] \\
\hline $\begin{array}{l}\mathrm{ZSM}-5(\mathrm{MFI}) \text { with } \\
\alpha-\mathrm{Al}_{2} \mathrm{O}_{3} \text { support }\end{array}$ & n.a. & n.a & n.a. & n.a. & 3 & [197] \\
\hline ZSM-5/polymeric silica & n.a. & 373 & 1140 & n.a. & & [198] \\
\hline $\begin{array}{l}\text { Stainless steel support infiltrated } \\
\text { with a eutectic molten carbonate } \\
\text { mixture }(\mathrm{Li} / \mathrm{Na} / \mathrm{K})\end{array}$ & n.a. & 923 & 7780 & n.a. & 16 & [199] \\
\hline Y-type & n.a. & $303-403$ & $35900-89800$ & n.a. & 5 & [200] \\
\hline $\mathrm{NaY}$ & n.a. & 313 & 359000 & n.a. & 5 & {$[200]$} \\
\hline $\operatorname{Li}(20 \%) \mathrm{Y}$ & n.a. & 308 & 210000 & n.a. & 3 & [200] \\
\hline $\mathrm{K}(30 \%) \mathrm{Y}$ & n.a. & 308 & 269000 & n.a. & 9 & [200] \\
\hline $\mathrm{K}(62 \%) \mathrm{Y}$ & n.a. & 313 & 150000 & n.a. & 6 & [200] \\
\hline $\mathrm{Rb}(38 \%) \mathrm{Y}$ & n.a. & 313 & 150000 & n.a. & 3 & {$[200]$} \\
\hline $\mathrm{Cs}(32 \%) \mathrm{Y}$ & n.a. & 313 & 59900 & n.a. & 2 & [200] \\
\hline $20 \% \mathrm{~K}_{2} \mathrm{CO}_{3}, 80 \% \mathrm{Li}_{2} \mathrm{CO}_{3}$ & n.a. & 798 & 2990 & n.a. & 4 & {$[199]$} \\
\hline $\mathrm{MCM}-48$ & n.a. & n.a. & 10200 & n.a. & 0.8 & {$[189]$} \\
\hline PEI-modified MCM-48 & n.a. & 363 & 14100 & n.a. & 80 & {$[201]$} \\
\hline Chitosan & 1.75 & 295 & 100 & n.a. & 100 & {$[192]$} \\
\hline Swollen chitosan & 1.5 & 383 & 482 & n.a. & 250 & {$[192]$} \\
\hline Arginine salt-chitosan & 1.5 & 383 & 1500 & n.a. & 852 & {$[194]$} \\
\hline \multicolumn{7}{|c|}{ Polyacetylene } \\
\hline Polytrimethyl-prop-1-ynyl-silane & n.a. & 298 & 19000 & 1800 & 10.6 & [193] \\
\hline Poly-3,3-dimethyl-but-1-yne & n.a. & 298 & 560 & 43 & 13.0 & [193] \\
\hline $\begin{array}{l}\text { Poly-1-(dimethyl- } \\
\text { trimethylsilanylmethyl-silanyl)- } \\
\text { propyne }\end{array}$ & n.a. & 298 & 310 & 21 & 14.8 & [193] \\
\hline $\begin{array}{l}\text { Poly-1-[dimethyl-(2- } \\
\text { trimethylsilanyl-ethyl)-silanyl]- } \\
\text { propyne }\end{array}$ & n.a. & 298 & 150 & 14 & 10.7 & {$[193]$} \\
\hline $\begin{array}{l}\text { Polytrimethyl-(2-prop-1-ynyl- } \\
\text { phenyl)-silane }\end{array}$ & n.a. & 298 & 290 & 24 & 12.1 & {$[193]$} \\
\hline $\begin{array}{l}\text { Poly-1-prop-1-ynyl-2- } \\
\text { trifluoromethyl-benzene }\end{array}$ & n.a. & 298 & 130 & 7.3 & 17.8 & {$[193]$} \\
\hline Poly-dec-2-yne & n.a. & 298 & 130 & 14 & 9.3 & [193] \\
\hline Poly-1-chloro-dec-1-yne & n.a. & 298 & 170 & 16 & 10.6 & [193] \\
\hline Poly-1-chloro-oct-1-yne & n.a. & 298 & 130 & 11 & 11.8 & {$[193]$} \\
\hline Poly-1-chloro-hex-1-yne & n.a. & 298 & 180 & 10 & 18 & [193] \\
\hline $\begin{array}{l}\text { Polyhexyl-dimethyl-prop-1-ynyl- } \\
\text { silane }\end{array}$ & n.a. & 298 & 71 & 4.3 & 16.5 & [193] \\
\hline $\begin{array}{l}\text { Polytrimethyl-(1-pentyl-prop-2- } \\
\text { ynyl)-silane }\end{array}$ & n.a. & 298 & 120 & 8.7 & 13.8 & {$[193]$} \\
\hline $\begin{array}{l}\text { Polyhexyl-dimethyl-(1-propyl- } \\
\text { prop-2-ynyl)-silane }\end{array}$ & n.a. & 298 & 70 & 6.3 & 11.1 & [193] \\
\hline Polyprop-1-ynyl-benzene & n.a. & 298 & 25 & 2.2 & 11.4 & [193] \\
\hline Polybut-1-ynyl-benzene & n.a. & 298 & 40 & 4.5 & 8.9 & {$[193]$} \\
\hline Polyoct-1-ynyl-benzene & n.a. & 298 & 48 & 5.5 & 8.7 & [193] \\
\hline Polychloroethynyl-benzene & n.a. & 298 & 23 & 1.0 & 23.0 & [193] \\
\hline
\end{tabular}


TABle 6: Continued.

\begin{tabular}{|c|c|c|c|c|c|c|}
\hline Name & $\begin{array}{l}\text { Feed pressure } \\
(\text { atm })\end{array}$ & $\begin{array}{c}\text { Temperature } \\
(\mathrm{K})\end{array}$ & $\begin{array}{l}P^{*}\left(\mathrm{CO}_{2}\right) \\
\text { (barrer) }\end{array}$ & $\begin{array}{l}P^{*}\left(\mathrm{~N}_{2}\right) \\
\text { (barrer) }\end{array}$ & $\begin{array}{c}\alpha \\
\left(\mathrm{CO}_{2} / \mathrm{N}_{2}\right) \\
\end{array}$ & Reference \\
\hline Poly-1-ethynyl-2-methyl-benzene & n.a. & 298 & 15 & 3.0 & 5.0 & [193] \\
\hline $\begin{array}{l}\text { Polydimethyl-phenyl-(1-propyl- } \\
\text { prop-2-ynyl)-silane }\end{array}$ & n.a. & 298 & 54 & 2.5 & 21.6 & [193] \\
\hline \multicolumn{7}{|c|}{ Polyarylene ether } \\
\hline 6FPT-6FBPA & 1.0 & 308 & 25.29 & 2.18 & 11.6 & [193] \\
\hline 6FPT-BPA 1.035 & 1.0 & 308 & 18.53 & 1.37 & 13.5 & [193] \\
\hline 6FPРy-6FBPA & 1.0 & 308 & 29.46 & 2.39 & 12.32 & [193] \\
\hline 6FPРy-BPA & 1.0 & 308 & 21.44 & 1.70 & 12.6 & [193] \\
\hline \multicolumn{7}{|c|}{ Fixed site carrier membrane (FSCM) } \\
\hline Polarix & 2.0 & 303 & $10^{7}$ & n.a. & 50 & {$[202]$} \\
\hline PAAM-PVA/PS & 10 & 298 & $2.4 \times 10^{5}$ & n.a. & 80 & [203] \\
\hline PVAm/PVA blend & 1.45 & 298 & $2.12 \times 10^{6}$ & n.a. & 145 & [204] \\
\hline PEI/PVA & n.a. & 298 & $10^{4}$ & n.a. & 230 & {$[184]$} \\
\hline PDMA/PS & 2 & 296 & $3 \times 10^{5}$ & n.a. & 53 & {$[143]$} \\
\hline \multicolumn{7}{|c|}{ Polyamine } \\
\hline PA12 & 10 & 308 & 120 & n.a. & 51 & {$[152]$} \\
\hline PA6 & 10 & 308 & 66 & n.a. & 56 & {$[152]$} \\
\hline $\begin{array}{l}\text { Polyethyleneimine/polyvinyl } \\
\text { butyral }\end{array}$ & 0.132 & 318 & 380 & n.a. & 32 & {$[193]$} \\
\hline $\begin{array}{l}\text { Poly }[(2-\mathrm{N}, \mathrm{N} \text {-dimethyl }) \\
\text { aminoethyl methacrylate }]\end{array}$ & 0.237 & 298 & 370 & n.a. & 111 & {$[193]$} \\
\hline $\begin{array}{l}\text { Poly(vinylbenzyltrimethyl } \\
\text { ammonium fluoride) }\end{array}$ & 0.224 & 296 & 113 & n.a. & 983 & {$[193]$} \\
\hline $\begin{array}{l}\text { Polyethyleneimine/poly(vinyl } \\
\text { alcohol) }\end{array}$ & 0.355 & 298 & 650 & n.a. & 235 & {$[193]$} \\
\hline PEI/PDMS/PEBA1657/PDMS & 5 & 298 & $1.57 \times 10^{6}$ & n.a. & 64 & {$[205]$} \\
\hline \multicolumn{7}{|c|}{ Polyarylate } \\
\hline BPA/IA & 10 & 308 & 5.4 & 0.24 & 22.5 & [193] \\
\hline $\mathrm{BPA} / \mathrm{tBIA}$ & 10 & 308 & 24.2 & 1.20 & 20.2 & [193] \\
\hline HFBPA/IA & 10 & 308 & 19.1 & 1.11 & 17.2 & {$[193]$} \\
\hline HFBPA/tBIA & 10 & 308 & 56.9 & 3.88 & 14.7 & {$[193]$} \\
\hline PhTh/IA & 10 & 308 & 6.74 & 0.28 & 24.1 & [193] \\
\hline $\mathrm{PhTh} / \mathrm{tBIA}$ & 10 & 308 & 23.8 & 1.09 & 21.8 & [193] \\
\hline FBP/IA & 10 & 308 & 12.4 & 0.57 & 12.4 & {$[193]$} \\
\hline $\mathrm{FBP} / \mathrm{tBIA}$ & 10 & 308 & 36.8 & 1.93 & 19.1 & [193] \\
\hline TBВPA/IA & 10 & 308 & 4.93 & 0.18 & 27.4 & [193] \\
\hline TBBPA/tBIA & 10 & 308 & 21.5 & 0.90 & 23.9 & {$[193]$} \\
\hline TBHFBPA/IA & 10 & 308 & 25.6 & 1.07 & 23.9 & [193] \\
\hline TBHFBPA/tBIA & 10 & 308 & 85.1 & 4.47 & 19.0 & [193] \\
\hline TBPhTh/IA & 10 & 308 & 8.34 & 0.29 & 28.8 & [193] \\
\hline TBPhTh/tBIA & 10 & 308 & 30.6 & 1.28 & 23.9 & [193] \\
\hline TBFBP/IA & 10 & 308 & 20.4 & 0.70 & 29.1 & [193] \\
\hline TBFBP/tBIA & 10 & 308 & 69.5 & 2.94 & 23.6 & [193] \\
\hline DMBPA/IA & 10 & 308 & 1.24 & 0.063 & 19.7 & [193] \\
\hline DMBPA/Tbia & 10 & 308 & 8.0 & 0.39 & 20.5 & [193] \\
\hline TMBPA/IA & 10 & 308 & 12.0 & 0.58 & 20.7 & [193] \\
\hline TMBPA/tBIA & 10 & 308 & 44.6 & 2.52 & 17.7 & [193] \\
\hline DiisoBPA/IA & 10 & 308 & 5.16 & 0.27 & 19.1 & [193] \\
\hline
\end{tabular}


TABle 6: Continued.

\begin{tabular}{|c|c|c|c|c|c|c|}
\hline Name & $\begin{array}{c}\text { Feed pressure } \\
(\mathrm{atm})\end{array}$ & $\begin{array}{c}\text { Temperature } \\
(\mathrm{K})\end{array}$ & $\begin{array}{c}P^{*}\left(\mathrm{CO}_{2}\right) \\
\text { (barrer) }\end{array}$ & $\begin{array}{l}P^{*}\left(\mathrm{~N}_{2}\right) \\
\text { (barrer) }\end{array}$ & $\begin{array}{c}\alpha \\
\left(\mathrm{CO}_{2} / \mathrm{N}_{2}\right)\end{array}$ & Reference \\
\hline DiisoBPA/tBIA & 10 & 308 & 16.1 & 1.08 & 14.9 & [193] \\
\hline DBDMBPA/IA & 10 & 308 & 5.45 & 0.22 & 24.8 & {$[193]$} \\
\hline PhAnth/IA & 10 & 308 & 9.0 & 0.36 & 25 & [193] \\
\hline PhAnth/tBIA & 10 & 308 & 25.9 & 1.35 & 19.2 & [193] \\
\hline FBP/IA & 10 & 308 & 12.4 & 0.57 & 21.8 & [193] \\
\hline $\mathrm{FBP} / \mathrm{tBIA}$ & 10 & 308 & 36.8 & 1.93 & 19.1 & {$[193]$} \\
\hline \multicolumn{7}{|c|}{ Polycarbonates } \\
\hline $\mathrm{PC}$ & $1-10$ & 308 & $6.0-6.8$ & $0.289-0.32$ & 21 & [193] \\
\hline TMPC & $1-10$ & 308 & $17.58-18.6$ & 1.0 & 18.6 & [193] \\
\hline TCPC & 1 & 308 & 6.66 & 0.36 & 18.5 & [193] \\
\hline TBPC & 1 & 308 & 4.23 & 0.182 & 23.2 & [193] \\
\hline HFPC & 10 & 308 & 24 & 1.6 & 15.0 & [193] \\
\hline TMHFPC & 10 & 308 & 111 & 7.4 & 15.0 & [193] \\
\hline NBPC & 10 & 308 & 9.1 & 0.47 & 19.4 & [193] \\
\hline PCZ & 10 & 308 & 2.2 & 0.105 & 21.0 & [193] \\
\hline PC-AP & 2 & 308 & 9.48 & 0.361 & 26.3 & [193] \\
\hline FBPC & 2 & 308 & 15.1 & 0.592 & 25.5 & [193] \\
\hline \multicolumn{7}{|c|}{ Polyethylene oxide } \\
\hline PEO & 7.8 & 298 & 8.1 & 0.07 & 140 & [193] \\
\hline $\mathrm{PEO}$ & $4.4-14.6$ & $308-318$ & $13-52$ & $0.24-1$ & 55 & [193] \\
\hline PEO-PBT & n.a. & 308 & 120 & 2 & 60 & [193] \\
\hline EO/EM/AGE (80/20/2) & n.a. & 308 & 773 & 16.8 & 46 & {$[193]$} \\
\hline EO/EM/AGE $(77 / 23 / 2.3)$ & n.a. & 308 & 680 & 15.5 & 44 & {$[193]$} \\
\hline EO/EM/AGE $(96 / 4 / 2.5)$ & n.a. & 308 & 580 & 12.1 & 48 & [193] \\
\hline \multicolumn{7}{|c|}{ Polyimides } \\
\hline Amine modified polyimide & 0.368 & 308 & 186 & n.a. & 38 & {$[193]$} \\
\hline PMDA-BAPHF & 6.8 & 308 & 11.8 & 0.66 & 17.8 & [193] \\
\hline PMDA-3BAPHF & 6.8 & 308 & 6.12 & 0.29 & 21.1 & [193] \\
\hline PMDA- $4,4^{\prime}-\mathrm{ODA}$ & $6.8-10$ & 308 & $1.14-2.7$ & $0.049-0.1$ & 23.3 & {$[193]$} \\
\hline PMDA-3,3'-ODA & $6.8-10$ & 308 & $0.50-3.55$ & $\begin{array}{c}0.018- \\
0.145\end{array}$ & $24.5-27.8$ & [193] \\
\hline PMDA-MDA & 10 & 308 & 4.03 & 0.20 & 20.2 & [193] \\
\hline PMDA-IPDA & 10 & 308 & 29.7 & 1.50 & 19.8 & [193] \\
\hline PMDA-BAPHF & 10 & 308 & 17.6 & 0.943 & 18.7 & {$[193]$} \\
\hline PMDA-BATPHF & 10 & 308 & 24.6 & 1.50 & 16.4 & {$[193]$} \\
\hline BPDA-BAHF & $1-10$ & $298-308$ & $23-27.7$ & $0.6-1.39$ & $19.9-37.7$ & [193] \\
\hline BPDA-mTrMPD & 10 & 308 & 137 & 8.42 & 16.3 & [193] \\
\hline BTDA-4,4-ODA & 10 & 308 & 0.625 & 0.0236 & 26.5 & [193] \\
\hline BTDA-BAPHF & 10 & 308 & 4.37 & 0.195 & 22.4 & [193] \\
\hline BTDA-BAHF & 10 & 308 & 10.1 & 0.45 & 22.4 & {$[193]$} \\
\hline BTDA-mTrMPD & 10 & 308 & 30.9 & 1.55 & 19.9 & [193] \\
\hline BTDA-BAFL & 1 & 298 & 15 & 0.39 & 38.5 & [193] \\
\hline PI & 10 & 308 & 2.00 & 0.063 & 31.7 & [193] \\
\hline oMeCat-durene & 1 & 303 & 27 & 0.83 & 33 & [193] \\
\hline mMeCat-durene & 1 & 303 & 20 & 0.59 & 34 & {$[193]$} \\
\hline DMeCat-durene & 1 & 303 & 63 & 2.05 & 31 & [193] \\
\hline
\end{tabular}


Table 6: Continued.

\begin{tabular}{|c|c|c|c|c|c|c|}
\hline Name & $\begin{array}{c}\text { Feed pressure } \\
(\mathrm{atm})\end{array}$ & $\begin{array}{c}\text { Temperature } \\
(\mathrm{K})\end{array}$ & $\begin{array}{l}P^{*}\left(\mathrm{CO}_{2}\right) \\
\text { (barrer) }\end{array}$ & $\begin{array}{l}P^{*}\left(\mathrm{~N}_{2}\right) \\
\text { (barrer) }\end{array}$ & $\begin{array}{c}\alpha \\
\left(\mathrm{CO}_{2} / \mathrm{N}_{2}\right) \\
\end{array}$ & Reference \\
\hline mtBuCat-durene & 1 & 303 & 71 & 2.55 & 28 & [193] \\
\hline oMeptBuCat-durene & 1 & 303 & 67 & 2.5 & 27 & [193] \\
\hline TMeCat-durene & 1 & 303 & 200 & 8.1 & 25 & {$[193]$} \\
\hline mMetCat-MDA & 1 & 303 & 22 & 0.65 & 34 & [193] \\
\hline mtBuCat-MDA & 1 & 303 & 63 & 2.2 & 29 & [193] \\
\hline TMeCat-MDA & 1 & 303 & 110 & 3.8 & 30 & {$[193]$} \\
\hline TMeCat-TMB & 1 & 303 & 39 & 1.2 & 33 & [193] \\
\hline DBuCat-TMB & 1 & 303 & 95 & 4.9 & 19 & [193] \\
\hline $\mathrm{mtBuCat}-\mathrm{DMOB}$ & 1 & 303 & 6.7 & 0.21 & 32 & [193] \\
\hline TMeCat-6FiPDA & 1 & 303 & 54 & 1.9 & 28 & [193] \\
\hline $6 \mathrm{~F}$ & 3 & n.a. & 114 & 5.8 & 19.6 & [193] \\
\hline TMMPD & 3 & n.a. & 600 & 35.1 & 17.1 & [193] \\
\hline IMDDM & 3 & n.a. & 196 & 10.8 & 18.1 & [193] \\
\hline ODA & 3 & n.a. & 25 & 0.97 & 25.8 & [193] \\
\hline Matrimid 5218 & 10 & 308 & 6.5 & 0.25 & 25.6 & [193] \\
\hline \multicolumn{7}{|c|}{ 6FDA-based polyimides } \\
\hline 6FDA-pPDA & 10 & 308 & 15.3 & 0.80 & 19.12 & [193] \\
\hline 6FDA-pDiMPDA & 10 & 303 & 42.7 & 2.67 & 16.0 & {$[193]$} \\
\hline 6FDA-durene & 10 & 308 & 440 & 35.60 & 12.4 & [193] \\
\hline 6FDA-durene & 10 & 303 & 456 & 35.50 & 12.85 & [193] \\
\hline 6FDA-mPDA & $6.8-10$ & 308 & $8.23-9.20$ & $0.36-0.447$ & $20.6-22.7$ & {$[193]$} \\
\hline 6FDA-mMPDA & $6.8-10$ & 303 & $40.1-42.5$ & $2.12-2.24$ & $17.9-20.1$ & [193] \\
\hline 6FDA-mTrMPDA & 10 & 308 & 431 & 31.6 & 13.6 & [193] \\
\hline 6FDA-DATr & 6.8 & 303 & 28.63 & 1.31 & 21.9 & [193] \\
\hline 6FDA-DBTF & 6.8 & 308 & 21.64 & 1.17 & 18.5 & [193] \\
\hline 6FDA-PHDoeP & 6.8 & 303 & 8.59 & 4.50 & 1.91 & [193] \\
\hline 6FDA-PEPE & 6.8 & 308 & 6.88 & 0.255 & 27.0 & [193] \\
\hline 6FDA-PBEPE & 6.8 & 303 & 2.50 & 0.099 & 25.3 & {$[193]$} \\
\hline 6FDA-PMeaP & 6.8 & 308 & 2.41 & 0.086 & 28.0 & [193] \\
\hline $6 \mathrm{FDA}-3,4^{\prime} \mathrm{ODA}$ & 10 & 303 & 6.11 & 0.259 & 23.6 & {$[193]$} \\
\hline 6FDA-APAP & 10 & 308 & 10.7 & 0.473 & 22.6 & [193] \\
\hline 6FDA-pp' ODA & 10 & 303 & 16.7 & 0.733 & 22.8 & {$[193]$} \\
\hline 6FDA-BAPHF & 10 & 308 & 19.1 & 0.981 & 19.5 & [193] \\
\hline 6FDA-BATPHF & 10 & 303 & 22.8 & 1.30 & 17.5 & [193] \\
\hline 6FDA-BAHF & 10 & 308 & 51.2 & 3.11 & 16.5 & [193] \\
\hline 6FDA-1,5-NDA & 10 & 308 & 23 & 1.1 & 21 & {$[193]$} \\
\hline 6FDA-durene $24 \mathrm{~h}$ amidation & 10 & n.a. & 11.6 & 1.33 & 8.75 & {$[193]$} \\
\hline 6FDA-durene/mPDA (50/50) & 10 & n.a. & 84.6 & 5.18 & 16.4 & {$[193]$} \\
\hline $\begin{array}{l}\text { 6FDA-durene/mPDA }(50 / 50) 4 \mathrm{~h} \\
\text { amidation }\end{array}$ & 10 & n.a. & 54.9 & 3.38 & 16.2 & [193] \\
\hline $\begin{array}{l}\text { 6FDA-durene/mPDA }(50 / 50) 6 \mathrm{~h} \\
\text { amidation }\end{array}$ & 10 & n.a. & 49.1 & 3.27 & 15.0 & {$[193]$} \\
\hline $\begin{array}{l}\text { 6FDA-durene/mPDA }(50 / 50) \\
12 \mathrm{~h} \text { amidation }\end{array}$ & 10 & n.a. & 46.0 & 2.94 & 15.6 & {$[193]$} \\
\hline
\end{tabular}


TABle 6: Continued.

\begin{tabular}{|c|c|c|c|c|c|c|}
\hline Name & $\begin{array}{l}\text { Feed pressure } \\
(\mathrm{atm})\end{array}$ & $\begin{array}{c}\text { Temperature } \\
(\mathrm{K})\end{array}$ & $\begin{array}{c}P^{*}\left(\mathrm{CO}_{2}\right) \\
\text { (barrer) }\end{array}$ & $\begin{array}{l}P^{*}\left(\mathrm{~N}_{2}\right) \\
\text { (barrer) }\end{array}$ & $\begin{array}{c}\alpha \\
\left(\mathrm{CO}_{2} / \mathrm{N}_{2}\right)\end{array}$ & Reference \\
\hline $\begin{array}{l}\text { 6FDA-durene/mPDA }(50 / 50) \\
24 \mathrm{~h} \text { amidation }\end{array}$ & 10 & n.a. & 36.0 & 2.06 & 17.5 & [193] \\
\hline $\begin{array}{l}\text { 6FDA-durene/mPDA }(50 / 50) \\
48 \mathrm{~h} \text { amidation }\end{array}$ & 10 & n.a. & 24.5 & 1.38 & 17.8 & [193] \\
\hline 6FDA-FDA/HFBAPP (1/1) & $1.1 \mathrm{~kg} / \mathrm{cm}^{2}$ & 303 & 465.0 & 19.9 & 23.4 & {$[193]$} \\
\hline 6FDA-ODA & 10 & 308 & 23 & 0.83 & 27.7 & [193] \\
\hline 6FDA-4,4-ODA & 6.8 & 303 & 22.0 & 0.94 & 23.4 & [193] \\
\hline 6FDA-MDA & 10 & 308 & 19 & 0.81 & 23.5 & [193] \\
\hline 6FDA-4BDAF & 6.8 & 303 & 19 & 0.98 & 19.4 & {$[193]$} \\
\hline 6FDA-3,3'-ODA & 6.8 & 308 & 2.1 & 0.10 & 21 & [193] \\
\hline 6FDA-3BDAF & 6.8 & 303 & 6.3 & 0.24 & 26.3 & [193] \\
\hline 6FDA-IPDA & 10 & $308-328$ & $24.3-27.4$ & $0.87-1.39$ & $19.7-27.9$ & [193] \\
\hline 6FDA-DAF & 10 & $308-328$ & $19.5-21.3$ & $0.81-1.15$ & $18.5-24.1$ & [193] \\
\hline PI-1 & 1 & 303 & 32 & 1.4 & 22.9 & [193] \\
\hline PI-3 & 1 & 303 & 360 & 16.5 & 21.8 & [193] \\
\hline PI-4 & 1 & 303 & 62 & 2.4 & 25.8 & [193] \\
\hline PI-5 & 1 & 303 & 190 & 7.3 & 26.0 & {$[193]$} \\
\hline 6FDA-BAFL & 1 & 298 & 98 & 3.3 & 29.7 & [193] \\
\hline \multicolumn{7}{|c|}{ Poly(phenylene oxide) } \\
\hline PPO (hollow fiber) & 4 & 308 & $10^{6}$ & & 21 & {$[205]$} \\
\hline PPS & 1.5 & 308 & 1.60 & 0.046 & 34.8 & [193] \\
\hline PDMPO & 1.5 & 308 & 65.5 & 3.5 & 18.7 & [193] \\
\hline PDPPO & 1.5 & 308 & 39.9 & 1.5 & 26.6 & [193] \\
\hline PDMPO & 6.891 & 295 & 90.0 & 3.7 & 24.3 & [193] \\
\hline PDMPO (20.0\% brominated) & 6.891 & 295 & 93.6 & 3.8 & 24.6 & [193] \\
\hline PDMPO (37.4\% brominated) & 6.891 & 295 & 97.1 & 3.7 & 26.2 & [193] \\
\hline PDMPO (60.0\% brominated) & 6.891 & 295 & 159.9 & 8.0 & 20.0 & [193] \\
\hline \multicolumn{7}{|c|}{ Polypyrrole } \\
\hline 6FDA-TAB & 10 & 308 & 54.0 & 2.6 & 20.8 & [193] \\
\hline 6FDA-TADPO & 10 & 308 & 27.6 & 1.2 & 23.0 & [193] \\
\hline BBL & 10 & 308 & 0.12 & 0.003 & 46.3 & [193] \\
\hline \multicolumn{7}{|c|}{ Polysulfones } \\
\hline PSF & 10 & 308 & 5.6 & 0.25 & 22.4 & [193] \\
\hline TMPSF & 10 & 308 & 21 & 1.06 & 19.8 & [193] \\
\hline HFPSF & 10 & 308 & 12 & 0.67 & 17.9 & [193] \\
\hline TMHFPSF & 10 & 308 & 72 & 4.0 & 18 & [193] \\
\hline PSF-F & 10 & 308 & 4.5 & 0.20 & 22.5 & [193] \\
\hline PSF-O & 10 & 308 & 4.3 & 0.20 & 21.5 & [193] \\
\hline PSF-P & 10 & 308 & 6.8 & 0.32 & 21.3 & [193] \\
\hline TMPSF-F & 10 & 308 & 5.5 & 0.61 & 9.0 & [193] \\
\hline TMPSF-P & 10 & 308 & 13.2 & 0.57 & 23.2 & [193] \\
\hline BIPSF & 10 & 308 & 5.6 & 0.24 & 23.3 & {$[193]$} \\
\hline TMBIPSF & 10 & 308 & 31.8 & 1.21 & 26.3 & [193] \\
\hline 1,5-NPSF & 10 & 308 & 1.6 & 0.057 & 28.1 & {$[193]$} \\
\hline 2,6-NPSF & 10 & 308 & 1.5 & 0.051 & 29.4 & [193] \\
\hline 2,7-NPSF & 10 & 308 & 1.8 & 0.074 & 24.3 & [193] \\
\hline
\end{tabular}


TABLE 6: Continued.

\begin{tabular}{|c|c|c|c|c|c|c|}
\hline Name & $\begin{array}{c}\text { Feed pressure } \\
\text { (atm) }\end{array}$ & $\begin{array}{c}\text { Temperature } \\
(\mathrm{K})\end{array}$ & $\begin{array}{c}P^{*}\left(\mathrm{CO}_{2}\right) \\
\text { (barrer) }\end{array}$ & $\begin{array}{l}P^{*}\left(\mathrm{~N}_{2}\right) \\
\text { (barrer) }\end{array}$ & $\begin{array}{c}\alpha \\
\left(\mathrm{CO}_{2} / \mathrm{N}_{2}\right) \\
\end{array}$ & Reference \\
\hline DMPSF & 10 & 308 & 2.1 & 0.091 & 23.1 & [193] \\
\hline HMBIPSF & 10 & 308 & 25.5 & 1.2 & 23.3 & [193] \\
\hline DMPSF-Z & 10 & 308 & 1.4 & 0.057 & 24.6 & [193] \\
\hline PSF-AP & 2 & 308 & 8.12 & 0.278 & 29.2 & [193] \\
\hline FBPSF & 2 & 308 & 13.8 & 0.484 & 28.5 & [193] \\
\hline PSF-M & 1 & 308 & 2.8 & 0.11 & 25.5 & [193] \\
\hline TMPSF-M & 10 & 308 & 7.0 & 0.28 & 25.0 & [193] \\
\hline PSF-BPFL & 1 & 308 & 10 & 0.25 & 40 & [193] \\
\hline $3,4^{\prime}$-PSF & 1 & 308 & 1.5 & 0.066 & 22.7 & [193] \\
\hline 1,3-ADM PSF & 35 & 308 & 7.2 & 0.33 & 21.8 & [193] \\
\hline 2,2-ADM PSF & 35 & 308 & 9.5 & 0.46 & 20.6 & [193] \\
\hline $\operatorname{PSF}\left(6 \% \mathrm{Br}, 92 \% \mathrm{C} \equiv \mathrm{CSiMe}_{3}\right)$ & 1 & 308 & 36.5 & 2.1 & 17.4 & [193] \\
\hline $\operatorname{PSF}\left(3 \% \mathrm{Br}, 47 \% \mathrm{C} \equiv \mathrm{CSiMe}_{3}\right)$ & 1 & 308 & 18.5 & 1.24 & 14.9 & {$[193]$} \\
\hline $\operatorname{PSF}\left(21 \% \mathrm{Br}, 77 \% \mathrm{C} \equiv \mathrm{CSiMe}_{3}\right)$ & 1 & 308 & 28.2 & 1.7 & 16.6 & [193] \\
\hline $\operatorname{PSF}\left(5 \% \mathrm{Br}, 45 \% \mathrm{C} \equiv \mathrm{CSiMe}_{3}\right)$ & 1 & 308 & 16.4 & 0.9 & 18.2 & {$[193]$} \\
\hline PSF & 1 & 308 & 5.6 & 0.25 & 22.4 & [193] \\
\hline PSF-s-HBTMS & 1 & 308 & 21 & 0.96 & 22.2 & [193] \\
\hline PSF-o-HBTMS & 1 & 308 & 70 & 3.29 & 21.3 & [193] \\
\hline PSF-CH2-TMS & 1 & 308 & 18 & 0.95 & 18.9 & {$[193]$} \\
\hline EM3 & 1 & 308 & 29 & 1.3 & 22 & [193] \\
\hline EM2 & 1 & 308 & 6.2 & 0.24 & 26 & [193] \\
\hline EM1 & 1 & 308 & 4.8 & 0.16 & 30 & [193] \\
\hline $\begin{array}{l}\text { SM3 }(\text { degree of substitution }= \\
2.0)\end{array}$ & 1 & 308 & 18 & 0.77 & 23 & {$[193]$} \\
\hline SM3 $($ degree of substitution $=1.0)$ & 1 & 308 & 10 & 0.38 & 26 & {$[193]$} \\
\hline SM1 & 1 & 308 & 5.1 & 0.17 & 30 & {$[193]$} \\
\hline PPSF & 1 & 308 & 3.2 & 0.10 & 32 & {$[193]$} \\
\hline RM3 & 1 & 308 & 27 & 1.9 & 14 & [193] \\
\hline RM2 & 1 & 308 & 6.7 & 0.60 & 11 & {$[193]$} \\
\hline RM1 & 1 & 308 & 6.9 & 0.61 & 11 & [193] \\
\hline HFPSF & 1 & 308 & 12.0 & 0.67 & 17.9 & [193] \\
\hline HFPSF- $o$-HBTMS & 1 & 308 & 105 & 5.63 & 18.6 & [193] \\
\hline HFPSF- $s$-TMS & 1 & 308 & 41 & 2.0 & 20 & [193] \\
\hline HFPSF- o-TMS & 1 & 308 & 84 & 4.7 & 18 & [193] \\
\hline HFPSF-TMS & 1 & 308 & 110 & 6.3 & 18 & [193] \\
\hline TM6FPSF & 1 & 308 & 72 & 4.0 & 18 & [193] \\
\hline TM6FPSF-s-TMS & 1 & 308 & 96 & 5.2 & 19 & [193] \\
\hline TMPSF-TMS & 1 & 308 & 32 & 1.51 & 21.3 & [193] \\
\hline TMPSF-s-TMS & 1 & 308 & 66.3 & 3.07 & 21.6 & [193] \\
\hline TMPSF-HBTMS & 1 & 308 & 72 & 3.36 & 21.4 & [193] \\
\hline \multicolumn{7}{|c|}{ Other membranes } \\
\hline HQDPA-PDA & 7 & 303 & 0.598 & 0.016 & 37.4 & [193] \\
\hline HQDPA-PDA & 7 & 373 & 1.70 & 0.111 & 15.3 & [193] \\
\hline HQDPA-DBA & 7 & 303 & 0.683 & 0.015 & 45.5 & [193] \\
\hline HQDPA-DBA & 7 & 373 & 2.10 & 0.125 & 16.8 & [193] \\
\hline HQDPA-MDBA & 7 & 303 & 1.18 & 0.034 & 34.7 & [193] \\
\hline
\end{tabular}


TABle 6: Continued.

\begin{tabular}{|c|c|c|c|c|c|c|}
\hline Name & $\begin{array}{l}\text { Feed pressure } \\
(\text { atm) }\end{array}$ & $\begin{array}{c}\text { Temperature } \\
(\mathrm{K})\end{array}$ & $\begin{array}{l}P^{*}\left(\mathrm{CO}_{2}\right) \\
\text { (barrer) }\end{array}$ & $\begin{array}{l}P^{*}\left(\mathrm{~N}_{2}\right) \\
\text { (barrer) }\end{array}$ & $\begin{array}{c}\alpha \\
\left(\mathrm{CO}_{2} / \mathrm{N}_{2}\right) \\
\end{array}$ & Reference \\
\hline HQDPA-MDBA & 7 & 373 & 2.37 & 0.160 & 14.8 & [193] \\
\hline HQDPA-EDBA & 7 & 303 & 2.26 & 0.077 & 29.4 & [193] \\
\hline HQDPA-EDBA & 7 & 373 & 4.18 & 0.292 & 14.3 & [193] \\
\hline $12 \mathrm{H}$ & 5 & 308 & 4.6 & 0.21 & 21.9 & [193] \\
\hline $6 \mathrm{H} 6 \mathrm{~F}$ & 5 & 308 & 8.6 & 0.44 & 19.5 & [193] \\
\hline $6 \mathrm{~F} 6 \mathrm{H}$ & 5 & 308 & 8.9 & 0.42 & 21.2 & [193] \\
\hline $12 \mathrm{~F}$ & 5 & 308 & 12.9 & 0.76 & 17.0 & [193] \\
\hline PBK & 10 & 308 & 3.3 & 0.13 & 25.4 & [193] \\
\hline PBK-S & 10 & 308 & 3.27 & 0.11 & 29.7 & [193] \\
\hline PBSF & 10 & 308 & 10.8 & 0.47 & 23.0 & [193] \\
\hline PES/PI & 4 & 308 & $1.15 \times 10^{5}$ & n.a. & 30 & {$[193]$} \\
\hline PPES & n.a. & 273 & 0.92 & 0.027 & 34 & [193] \\
\hline PPESK & n.a. & 273 & 0.75 & 0.042 & 18 & [193] \\
\hline $\begin{array}{l}20 \text { percent DEA immobilized in } \\
25.4 \mu \mathrm{m} \text { microporous } \\
\text { polypropylene supports }\end{array}$ & $0.16-1.67$ & 298 & $974-4825$ & n.a. & $56-276$ & {$[200]$} \\
\hline \multicolumn{7}{|c|}{ Copolymers and polymer blend } \\
\hline PEBA 2533 (hollow fiber) & 6.8 & 273 & 260 & n.a. & 32 & {$[206]$} \\
\hline PEBA/PSF composite & 3.4 & 273 & $6.1 \times 10^{5}$ & n.a. & 30 & [206] \\
\hline COPNA & n.a. & 373 & 2990 & n.a. & 14 & {$[200]$} \\
\hline Pebax & n.a. & 303 & 73 & n.a. & 15.6 & [207] \\
\hline Pebax/PEG10 & n.a. & 303 & 75 & n.a. & 15.8 & {$[207]$} \\
\hline Pebax/PEG20 & n.a. & 303 & 80 & n.a. & 15.9 & {$[207]$} \\
\hline Pebax/PEG30 & n.a. & 303 & 105 & n.a. & 15.1 & {$[207]$} \\
\hline Pebax/PEG40 & n.a. & 303 & 132 & n.a. & 15.1 & {$[207]$} \\
\hline Pebax/PEG50 & n.a. & 303 & 151 & n.a. & 15.5 & [207] \\
\hline Pebax/PEG-DME10 & n.a. & 303 & 123 & n.a. & 44 & {$[208]$} \\
\hline Pebax/PEG-DME20 & n.a. & 303 & 206 & n.a. & 45 & {$[208]$} \\
\hline Pebax/PEG-DME30 & n.a. & 303 & 300 & n.a. & 46 & {$[208]$} \\
\hline Pebax/PEG-DME40 & n.a. & 303 & 440 & n.a. & 42 & [208] \\
\hline Pebax/PEG-DME50 & n.a. & 303 & 606 & n.a. & 43 & {$[208]$} \\
\hline 6FDA-TAB & 10 & 308 & 54.0 & 2.8 & 19.3 & [193] \\
\hline 6FDA/PMDA-TAB $(50: 50)$ & 10 & 308 & 15.8 & 0.70 & 22.6 & [193] \\
\hline 6FDA/PMDA-TAB (25:75) & 10 & 308 & 3.13 & 0.098 & 31.9 & {$[193]$} \\
\hline 6FDA/PMDA-TAB (10/90) & 10 & 308 & 1.11 & 0.036 & 30.8 & [193] \\
\hline 6FDA-TAB/DAM (75/25) & 3 & 308 & 73.7 & 3.1 & 23.8 & [193] \\
\hline 6FDA-TAB/DAM (50/50) & 3 & 308 & 155 & 6.6 & 23.5 & {$[193]$} \\
\hline 6FDA-DAM & 3 & 308 & 370 & 29.5 & 12.5 & [193] \\
\hline 6FDA/TMPDA & n.a. & 308 & 400 & 23.5 & 17.02 & [193] \\
\hline $\begin{array}{l}\text { 6FDA/PMDA }(1: 6)-T M M D A \\
\left(\mathrm{CH}_{2} \mathrm{Cl}_{2} \text { cast }\right)\end{array}$ & 10 & 308 & 187 & 11.7 & 16.0 & {$[193]$} \\
\hline $\begin{array}{l}\text { 6FDA/PMDA }(1: 6)-T M M D A \\
\text { (NMP cast) }\end{array}$ & 10 & 308 & 144 & 8.76 & 16.4 & {$[193]$} \\
\hline $\begin{array}{l}\text { 6FDA/PMDA }(1: 6)-T M M D A \\
\text { (DMF cast) }\end{array}$ & 10 & 308 & 88.6 & 5.16 & 17.2 & {$[193]$} \\
\hline MDI-BPA/PEG (75) & 2 & 308 & 31 & 0.70 & 44 & [193] \\
\hline MDI-BPA/PEG (80) & 2 & 308 & 48 & 1.0 & 47 & {$[193]$} \\
\hline MDI-BPA/PEG (85) & 2 & 308 & 59 & 1.20 & 49 & [193] \\
\hline L/TDI (20)-BPA/PEG (90) & 2 & 308 & 47 & 0.92 & 51 & [193] \\
\hline
\end{tabular}


TABle 6: Continued.

\begin{tabular}{|c|c|c|c|c|c|c|}
\hline Name & $\begin{array}{c}\text { Feed pressure } \\
(\mathrm{atm})\end{array}$ & $\begin{array}{c}\text { Temperature } \\
(\mathrm{K})\end{array}$ & $\begin{array}{c}P^{*}\left(\mathrm{CO}_{2}\right) \\
\text { (barrer) }\end{array}$ & $\begin{array}{l}P^{*}\left(\mathrm{~N}_{2}\right) \\
\text { (barrer) }\end{array}$ & $\begin{array}{c}\alpha \\
\left(\mathrm{CO}_{2} / \mathrm{N}_{2}\right)\end{array}$ & Reference \\
\hline L/TDI (40)-BPA/PEG (85) & 2 & 308 & 35 & 0.72 & 48 & [193] \\
\hline IPA-ODA/PEO3 (80) & 2 & 308 & 58 & 1.1 & 53 & [193] \\
\hline BPDA-pp'ODA & n.a. & 303 & 18000 & n.a. & 31 & {$[155]$} \\
\hline BPDA-ODA/DAT (oxidized) & n.a. & 308 & 599 & n.a. & 40 & {$[155]$} \\
\hline BPDA-ODA/DABA/PEO1 (75) & 2 & 308 & 2.7 & 0.048 & 56 & [193] \\
\hline BPDA-mDDS/PEO1 (80) & 2 & 308 & 3.8 & 0.066 & 58 & {$[193]$} \\
\hline BPDA-ODA/DABA/PEO2 (70) & 2 & 308 & 14 & 0.25 & 57 & {$[193]$} \\
\hline BPDA-ODA/DABA/PEO2 (80) & 2 & 308 & 36 & 0.64 & 56 & [193] \\
\hline BPDA-ODA/PEO3 (75) & 2 & 308 & 75 & 1.4 & 52 & [193] \\
\hline BPDA-mDDS/PEO3 (75) & 2 & 308 & 72 & 1.4 & 53 & [193] \\
\hline BPDA-mPD/PEO4 (80) & 2 & 308 & 81 & 1.5 & 54 & [193] \\
\hline BPDA-ODA/PEO4 (80) & 2 & 308 & 117 & 2.3 & 51 & {$[193]$} \\
\hline PMDA-ODA/DABA/PEO1 (80) & 2 & 308 & 14 & 0.27 & 52 & [193] \\
\hline PMDA-ODA/PEO2 (75) & 2 & 308 & 40 & 0.74 & 54 & [193] \\
\hline PMDA-mPD/PEO3 (80) & 2 & 308 & 99 & 2.0 & 50 & {$[193]$} \\
\hline PMDA-APPS/PEO3 (80) & 2 & 308 & 159 & 3.1 & 51 & {$[193]$} \\
\hline PMDA-APPS/PEO4 (70) & 2 & 308 & 136 & 2.6 & 53 & [193] \\
\hline PMDA-mPD/PEO4 (80) & 2 & 308 & 151 & 2.9 & 52 & [193] \\
\hline PMDA-ODA/PEO4 (80) & 2 & 308 & 167 & 3.2 & 52 & {$[152]$} \\
\hline PMDA-pDDS/PEO4 (80) & 2 & 308 & 238 & 4.9 & 49 & {$[152]$} \\
\hline PMDA/BTDA-BAFL $(50: 50)$ & 1 & 298 & 43 & 1.3 & 33 & [193] \\
\hline PMDA/BTDA-BAFL $(90: 10)$ & 1 & 298 & 130 & 3.8 & 34 & [193] \\
\hline BPDA-BAFL/HMDA $(50: 50)$ & 1 & 298 & 0.54 & 0.014 & 39 & [193] \\
\hline PPES & n.a. & 298 & 0.92 & 0.027 & 34 & [193] \\
\hline PPES/PPEK $(3: 1)$ & n.a. & 298 & 2.94 & 0.074 & 40 & {$[193]$} \\
\hline PPES/PPEK $(1: 1)$ & n.a. & 298 & 4.12 & 0.089 & 46 & [193] \\
\hline PPES/PPEK (1:3) & n.a. & 298 & 2.06 & 0.026 & 39 & [193] \\
\hline PPES/PPEK $(1: 4)$ & n.a. & 298 & 1.77 & 0.052 & 34 & [193] \\
\hline PPEK 18 & n.a. & 298 & 0.75 & 0.042 & 18 & {$[193]$} \\
\hline HQDPA-DPA/MDPA & 7 & 303 & 0.957 & 0.023 & 41.2 & [193] \\
\hline HQDPA-DPA/MDPA & 7 & 373 & 2.34 & 0.147 & 15.9 & [193] \\
\hline HQDPA-DPA/EDPA & 7 & 303 & 1.334 & 0.036 & 37.6 & [193] \\
\hline HQDPA-DPA/EDPA & 7 & 373 & 3.25 & 0.207 & 15.7 & [193] \\
\hline PI & 10 & 308 & 2.00 & 0.063 & 31.7 & {$[193]$} \\
\hline $\mathrm{PI} / 10 \mathrm{PS}$ & 10 & 308 & 2.33 & 0.085 & 27.4 & {$[193]$} \\
\hline PI/15PS & 10 & 308 & 2.32 & 0.09 & 25.8 & {$[193]$} \\
\hline $\mathrm{PI} / 20 \mathrm{PS}$ & 10 & 308 & 2.90 & 0.91 & 3.19 & [193] \\
\hline $\mathrm{PI} / 25 \mathrm{PS}$ & 10 & 308 & 4.29 & 0.91 & 4.71 & [193] \\
\hline PI/10PSVP & 10 & 308 & 3.58 & 0.13 & 28.4 & [193] \\
\hline PI/15PSVP & 10 & 308 & 3.71 & 0.14 & 26.5 & [193] \\
\hline PI/20PSVP & 10 & 308 & 5.65 & 0.15 & 38.4 & [193] \\
\hline $\mathrm{PI} / 25 \mathrm{PSVP}$ & 10 & 308 & 6.55 & 1.55 & 4.31 & [193] \\
\hline $\begin{array}{l}\text { NTDA-BDSA } \\
(30) / \text { CARDO/ODA }\end{array}$ & 3 & 303 & 70 & 1.7 & 41 & [193] \\
\hline
\end{tabular}


TABle 6: Continued.

\begin{tabular}{|c|c|c|c|c|c|c|}
\hline Name & $\begin{array}{c}\text { Feed pressure } \\
(\mathrm{atm})\end{array}$ & $\begin{array}{c}\text { Temperature } \\
(\mathrm{K})\end{array}$ & $\begin{array}{c}P^{*}\left(\mathrm{CO}_{2}\right) \\
\text { (barrer) }\end{array}$ & $\begin{array}{l}P^{*}\left(\mathrm{~N}_{2}\right) \\
\text { (barrer) }\end{array}$ & $\begin{array}{c}\alpha \\
\left(\mathrm{CO}_{2} / \mathrm{N}_{2}\right)\end{array}$ & Reference \\
\hline NTDA-BDSA (30)/CARDO] & 3 & 303 & 164 & 4.5 & 36 & {$[193]$} \\
\hline NTDA-BDSA (30)/BAPHF & 3 & 303 & 23 & 0.64 & 36 & [193] \\
\hline NTDA-BDSA (30)/ODA & 3 & 303 & 5.2 & 0.1 & 52 & [193] \\
\hline 6FDA-FDA/HFBAPP (1/1) & $1.1 \mathrm{~kg} / \mathrm{cm}^{2}$ & 303 & 465 & 19.9 & 23.4 & {$[193]$} \\
\hline 6FDA-durene/pPDA $(80 / 20)$ & 10 & 308 & 230 & 16.88 & 13.62 & [193] \\
\hline 6FDA-durene/pPDA (50/50) & 10 & 308 & 126 & 7.74 & 16.28 & [193] \\
\hline 6FDA-durene/pPDA $(20 / 80)$ & 10 & 308 & 59.26 & 2.81 & 21.09 & [193] \\
\hline 6FDA-durene/3,3'-DDS (75/25) & 10 & 308 & 84.7 & 5.91 & 14.3 & {$[193]$} \\
\hline 6FDA-durene $/ 3,3^{\prime}$-DDS $(50 / 50)$ & 10 & 308 & 19.8 & 1.09 & 18.2 & {$[193]$} \\
\hline 6FDA-durene $/ 3,3^{\prime}$-DDS (25/75) & 10 & 308 & 5.12 & 0.26 & 19.7 & [193] \\
\hline $6 \mathrm{FDA}-3,3^{\prime}-\mathrm{DDS}$ & 10 & 308 & 1.84 & 0.08 & 22.7 & [193] \\
\hline 6FDA-6FpDA-DABA-12.5 & 4 & 308 & 34.0 & 2.01 & 16.9 & [193] \\
\hline $\begin{array}{l}\text { 6FDA-6FpDA-DABA- } 12.5 \\
\text { annealed }\end{array}$ & 4 & 308 & 70.8 & 4.50 & 15.7 & {$[193]$} \\
\hline $\begin{array}{l}\text { 6FDA-6FpDA-DABA- } 12.5 \\
(22.5 \% \text { TMOS })\end{array}$ & 4 & 308 & 30.9 & 1.70 & 18.2 & [193] \\
\hline $\begin{array}{l}\text { 6FDA-6FpDA-DABA- } 12.5 \\
\text { (22.5\% TMOS) annealed }\end{array}$ & 4 & 308 & 47.6 & 3.16 & 15.1 & [193] \\
\hline $\begin{array}{l}\text { 6FDA-6FpDA-DABA-12.5 (15.0\% } \\
\text { MTMOS) }\end{array}$ & 4 & 308 & 44.0 & 2.53 & 17.4 & [193] \\
\hline $\begin{array}{l}\text { 6FDA-6FpDA-DABA-12.5 (15.0\% } \\
\text { MTMOS) annealed }\end{array}$ & 4 & 308 & 110 & 7.07 & 15.6 & [193] \\
\hline $\begin{array}{l}\text { 6FDA-6FpDA-DABA-12.5 (15.0\% } \\
\text { PTMOS) } 435\end{array}$ & 4 & 308 & 32.3 & 1.80 & 17.9 & [193] \\
\hline $\begin{array}{l}\text { 6FDA-6FpDA-DABA-12.5 (15.0\% } \\
\text { PTMOS) annealed }\end{array}$ & 4 & 308 & 91.8 & 5.59 & 16.4 & [193] \\
\hline $\begin{array}{l}\text { 6FDA-6FpDA-DABA- } 12.5 \\
(22.5 \% \text { PTMOS })\end{array}$ & 4 & 308 & 30.7 & 1.88 & 16.3 & [193] \\
\hline $\begin{array}{l}\text { 6FDA-6FpDA-DABA- } 12.5 \\
\text { (22.5\% PTMOS) annealed }\end{array}$ & 4 & 308 & 90.9 & 5.87 & 15.5 & [193] \\
\hline 6FDA-6FpDA-DABA-25 & 4 & 308 & 20.3 & 1.20 & 16.9 & {$[193]$} \\
\hline $\begin{array}{l}\text { 6FDA-6FpDA-DABA- } 25 \\
\text { annealed }\end{array}$ & 4 & 308 & 77.3 & 4.85 & 15.9 & [193] \\
\hline $\begin{array}{l}\text { 6FDA-6FpDA-DABA-25 (22.5\% } \\
\text { TMOS) }\end{array}$ & 4 & 308 & 15.7 & 1.06 & 14.8 & [193] \\
\hline $\begin{array}{l}\text { 6FDA-6FpDA-DABA-25 (22.5\% } \\
\text { TMOS) annealed }\end{array}$ & 4 & 308 & 79.8 & 4.87 & 16.4 & [193] \\
\hline $\begin{array}{l}\text { 6FDA-6FpDA-DABA-25 (15.0\% } \\
\text { MTMOS) }\end{array}$ & 4 & 308 & 16.6 & 1.07 & 15.5 & [193] \\
\hline $\begin{array}{l}\text { 6FDA-6FpDA-DABA-25 (15.0\% } \\
\text { MTMOS) annealed }\end{array}$ & 4 & 308 & 81.1 & 5.07 & 16.0 & [193] \\
\hline $\begin{array}{l}\text { 6FDA-6FpDA-DABA- } 25 \text { ( } 22.5 \% \\
\text { MTMOS) }\end{array}$ & 4 & 308 & 16.6 & 1.07 & 15.5 & [193] \\
\hline $\begin{array}{l}\text { 6FDA-6FpDA-DABA-25 (22.5\% } \\
\text { MTMOS) annealed }\end{array}$ & 4 & 308 & 60.1 & 3.837 & 15.7 & [193] \\
\hline $\begin{array}{l}\text { 6FDA-6FpDA-DABA-25 (15.0\% } \\
\text { PTMOS) }\end{array}$ & 4 & 308 & 18.4 & 0.94 & 19.6 & [193] \\
\hline $\begin{array}{l}\text { 6FDA-6FpDA-DABA-25 (15.0\% } \\
\text { PTMOS) annealed }\end{array}$ & 4 & 308 & 104 & 6.25 & 16.6 & [193] \\
\hline
\end{tabular}


TABle 6: Continued.

\begin{tabular}{|c|c|c|c|c|c|c|}
\hline Name & $\begin{array}{l}\text { Feed pressure } \\
(\mathrm{atm})\end{array}$ & $\begin{array}{c}\text { Temperature } \\
(\mathrm{K})\end{array}$ & $\begin{array}{l}P^{*}\left(\mathrm{CO}_{2}\right) \\
\text { (barrer) }\end{array}$ & $\begin{array}{l}P^{*}\left(\mathrm{~N}_{2}\right) \\
\text { (barrer) }\end{array}$ & $\begin{array}{c}\alpha \\
\left(\mathrm{CO}_{2} / \mathrm{N}_{2}\right) \\
\end{array}$ & Reference \\
\hline $\begin{array}{l}\text { 6FDA-6FpDA-DABA-25 (22.5\% } \\
\text { PTMOS) }\end{array}$ & 4 & 308 & 19.1 & 0.98 & 19.5 & [193] \\
\hline $\begin{array}{l}\text { 6FDA-6FpDA-DABA-25 (22.5\% } \\
\text { PTMOS) annealed }\end{array}$ & 4 & 308 & 104 & 6.25 & 16.6 & {$[193]$} \\
\hline $\operatorname{Poly}(5: 5 \mathrm{BPA} / \mathrm{BN})$ & 5 & 308 & 5.71 & 0.19 & 30.1 & [193] \\
\hline Poly(7 : 3 BPA/BN) & 5 & 308 & 4.62 & 0.16 & 28.9 & [193] \\
\hline \multicolumn{7}{|c|}{ Cross-linking polymers } \\
\hline $\begin{array}{l}\text { Poly(ethylene } \\
\text { oxide-co-epichlorohydrin) }(1: 1) \\
1.1 \%\end{array}$ & 300 & 298 & 15.0 & 2.3 & 6.52 & {$[193]$} \\
\hline $\begin{array}{l}\text { Poly(ethylene } \\
\text { oxide-co-epichlorohydrin) }(1: 1) \\
2 \%\end{array}$ & 300 & 298 & 14.9 & 1.0 & 14.9 & [193] \\
\hline $\begin{array}{l}\text { Poly(ethylene } \\
\text { oxide-co-epichlorohydrin) }(1: 1) \\
5 \%\end{array}$ & 300 & 298 & 16.1 & 0.5 & 32.2 & {$[193]$} \\
\hline DM14/MM9 (100/0) & 0.967 & 298 & 45 & 0.66 & 68 & [193] \\
\hline DM14/MM9 (100/0) & 0.967 & 323 & 107 & 2.8 & 38 & [193] \\
\hline DM14/MM9 (90/10) & 0.967 & 298 & 62 & 0.90 & 69 & {$[193]$} \\
\hline DM14/MM9 (90/10) & 0.967 & 323 & 133 & 3.4 & 39 & {$[193]$} \\
\hline DM14/MM9 (70/30) & 0.967 & 298 & 96 & 1.5 & 66 & [193] \\
\hline DM14/MM9 (70/30) & 0.967 & 323 & 195 & 5.4 & 36 & [193] \\
\hline DM14/MM9 (50/50) & 0.967 & 298 & 144 & 2.25 & 64 & [193] \\
\hline DM14/MM9 (50/50) & 0.967 & 323 & 260 & 7.2 & 36 & [193] \\
\hline DM14/MM9 (30/70) & 0.967 & 298 & 210 & 3.3 & 63 & [193] \\
\hline DM14/MM9 (30/70) & 0.967 & 323 & 350 & 10.6 & 33 & [193] \\
\hline DB30/MM9 (100/0) & 0.967 & 298 & 93 & 1.5 & 63 & {$[193]$} \\
\hline DB30/MM9 (100/0) & 0.967 & 323 & 200 & 5.7 & 35 & [193] \\
\hline DB30/MM9 (90/10) & 0.967 & 298 & 105 & 1.6 & 64 & {$[193]$} \\
\hline DB30/MM9 (90/10) & 0.967 & 323 & 210 & 5.8 & 36 & [193] \\
\hline DB30/MM9 (70/30) & 0.967 & 298 & 141 & 2.1 & 67 & [193] \\
\hline DB30/MM9 (70/30) & 0.967 & 323 & 270 & 7.7 & 35 & [193] \\
\hline DB30/MM9 (50/50) & 0.967 & 298 & 179 & 2.9 & 62 & {$[193]$} \\
\hline DB30/MM9 (50/50) & 0.967 & 323 & 330 & 9.7 & 34 & [193] \\
\hline DB30/MM9 (30/70) & 0.967 & 298 & 250 & 4.2 & 60 & [193] \\
\hline DB30/MM9 (30/70) & 0.967 & 323 & 410 & 12.4 & 33 & [193] \\
\hline DM9/MM9 (90/10) & 0.967 & 298 & 18.3 & 0.3 & 68 & {$[193]$} \\
\hline DM9/MM9 (90/10) & 0.967 & 323 & 51 & 1.3 & 38 & [193] \\
\hline DM23/MM9 (90/10) & 0.967 & 298 & 145 & 2.2 & 66 & {$[193]$} \\
\hline DM23/MM9 (90/10) & 0.967 & 323 & 290 & 7.6 & 38 & [193] \\
\hline DB10/MM9 (90/10) & 0.967 & 298 & 6.7 & 0.11 & 61 & [193] \\
\hline DB10/MM9 (90/10) & 0.967 & 323 & 27 & 0.79 & 34 & [193] \\
\hline DB69/MM9 (90/10) (cooling) & 0.967 & 298 & 240 & 4.3 & 56 & {$[193]$} \\
\hline DB69/MM9 (90/10) (cooling) & 0.967 & 323 & 510 & 14.2 & 36 & {$[193]$} \\
\hline DB69/MM9 (90/10) (heating) & 0.967 & 298 & 98 & 1.6 & 62 & [193] \\
\hline DB69/MM9 (90/10) (heating) & 0.967 & 323 & 400 & 11.4 & 35 & [193] \\
\hline DM14/MM23 (30/70) (cooling) & 0.967 & 298 & 240 & 3.9 & 62 & {$[193]$} \\
\hline DM14/MM23 (30/70) (cooling) & 0.967 & 323 & 420 & 12 & 35 & [193] \\
\hline
\end{tabular}


TABLE 6: Continued.

\begin{tabular}{|c|c|c|c|c|c|c|}
\hline Name & $\begin{array}{l}\text { Feed pressure } \\
\text { (atm) }\end{array}$ & $\begin{array}{c}\text { Temperature } \\
(\mathrm{K})\end{array}$ & $\begin{array}{c}P^{*}\left(\mathrm{CO}_{2}\right) \\
\text { (barrer) }\end{array}$ & $\begin{array}{l}P^{*}\left(\mathrm{~N}_{2}\right) \\
\text { (barrer) }\end{array}$ & $\begin{array}{c}\alpha \\
\left(\mathrm{CO}_{2} / \mathrm{N}_{2}\right)\end{array}$ & Reference \\
\hline DM14/MM23 (30/70) (heating) & 0.967 & 298 & 250 & 4.0 & 62 & {$[193]$} \\
\hline Matrimid 5218 & 10 & 308 & 6.5 & 0.25 & 25.6 & [193] \\
\hline $\begin{array}{l}\text { Matrimid 5218, 1-day } \\
\text { cross-linking }\end{array}$ & 10 & 308 & 7.4 & 0.29 & 25.6 & [193] \\
\hline $\begin{array}{l}\text { Matrimid 5218, 3-day } \\
\text { cross-linking }\end{array}$ & 10 & 308 & 6.0 & 0.24 & 25.2 & [193] \\
\hline $\begin{array}{l}\text { Matrimid 5218, 7-day } \\
\text { cross-linking }\end{array}$ & 10 & 308 & 5.1 & 0.21 & 24.6 & [193] \\
\hline $\begin{array}{l}\text { Matrimid 5218, 14-day } \\
\text { cross-linking }\end{array}$ & 10 & 308 & 4.7 & 0.19 & 24.1 & [193] \\
\hline $\begin{array}{l}\text { Matrimid 5218, 21-day } \\
\text { cross-linking }\end{array}$ & 10 & 308 & 3.4 & 0.15 & 22.2 & [193] \\
\hline $\begin{array}{l}\text { Matrimid 5218, 32-day } \\
\text { cross-linking }\end{array}$ & 10 & 308 & 1.9 & 0.13 & 15.0 & [193] \\
\hline 6FDA-durene, 5 min cross-linked & 10 & 308 & 136 & 11.1 & 12.3 & [193] \\
\hline $\begin{array}{l}\text { 6FDA-durene, } 10 \mathrm{~min} \\
\text { cross-linked }\end{array}$ & 10 & 308 & 91.8 & 6.53 & 14.1 & [193] \\
\hline $\begin{array}{l}\text { 6FDA-durene, } 15 \mathrm{~min} \\
\text { cross-linked }\end{array}$ & 10 & 308 & 70.0 & 6.05 & 11.6 & [193] \\
\hline $\begin{array}{l}\text { 6FDA-durene, } 30 \mathrm{~min} \\
\text { cross-linked }\end{array}$ & 10 & 308 & 30.3 & 2.87 & 10.6 & [193] \\
\hline $\begin{array}{l}\text { 6FDA-durene, } 60 \mathrm{~min} \\
\text { cross-linked }\end{array}$ & 10 & 308 & 2.14 & 0.40 & 5.35 & [193] \\
\hline
\end{tabular}

* Permeability.

dense. In porous inorganic membranes, a porous thin top layer is supported on a porous metal or ceramic support. Zeolite, silicon carbide, carbon, glass, zirconia, titania, and alumina membranes are mainly used as porous inorganic membranes supported on different substrates, such as $\alpha$ alumina, $\gamma$-alumina, zirconia, zeolite, or porous stainless steel $[17,199,209,210]$.

Zeolite membrane is the most important group of inorganic membranes. Zeolite membranes are considered more expensive than polymeric membranes, and therefore their unique properties of size selectivity and thermal and chemical stability should be exploited for successful application [211213].

The dense inorganic membranes (nonporous material) consist of a thin layer of metal, such as palladium and its alloys (metallic membrane), or solid electrolytes, such as zirconia. Another form of inorganic membrane is the liquidimmobilized membrane, where the pores of a membrane are completely filled with a liquid, which is permselective for certain compounds. Recently, attempts have been made to develop dense molten carbonate selective membranes for $\mathrm{CO}_{2}$ separation at high temperatures $(>723 \mathrm{~K})$. The inorganic membranes have high thermal stability for $\mathrm{CO}_{2}$ separation, but their selectivity and permeability are very low [200, 214, 215].

2.4.2. Polymeric Membranes. In polymeric membranes, the selective layer is generally a nonporous film that transports gases across by the solution-diffusion mechanism.
Polyacetylenes, polyaniline, polyarylene ethers, polyarylates, polycarbonates, polyetherimides, polyethylene oxide, polyimides, polyphenylene oxides, polypyrroles, polysulfones, and amino groups such as polyethyleneimine blends, polymethacrylates are examples of polymeric membranes used for $\mathrm{CO}_{2}$ separation $[17,216-218]$.

Selective polymeric membranes can be divided into two basic categories: glassy and rubbery. Almost glassy polymeric membranes are more suitable than rubbery polymeric membranes for $\mathrm{CO}_{2}$ separation because of their high gas selectivity and good mechanical properties. On the other hand, rubbery membranes are flexible and soft and they have a high permeability but a low selectivity, whereas glassy polymers exhibit a low permeability but a high selectivity [206, 219-221].

Several advantages of polymeric membranes are (i) low cost of production; (ii) high performance separation; (iii) ease of synthesis; and (iv) mechanical stability. Although the polymeric membranes have high selectivity and permeability for $\mathrm{CO}_{2}$ separation, but their thermal stability is very low, and these membrane may be plasticized with influence of $\mathrm{CO}_{2}$ in membrane. Therefore, application of these membranes for post-combustion capture is limited, and flue gas must first be cooled down to $313-333 \mathrm{~K}$ for membrane process $[184,222$, 223].

Ren et al. [205] prepared polymeric membranes with block copolymers; the balance of the hard and soft blocks can provide a good $\mathrm{CO}_{2}$ separation performance without loss of its permeability. 
TABLE 7: Comparison between various technologies used for $\mathrm{CO}_{2}$ capture.

\begin{tabular}{lll}
\hline Technology & Advantages & Disadvantages \\
\hline Absorption & $\begin{array}{l}\text { (i) React rapidly } \\
\text { (ii) High absorption capacities } \\
\text { (iii) Very flexible }\end{array}$ & $\begin{array}{l}\text { (i) Equipment corrosion } \\
\text { (ii) High energy required for regenerating } \\
\text { solvent }\end{array}$ \\
\hline Adsorption & $\begin{array}{l}\text { (i) Low energy consumption and cost of } \\
\mathrm{CO}_{2} \text { capture } \\
\text { (ii) Suitable for separating } \mathrm{CO}_{2} \text { from dilute } \\
\text { stream }\end{array}$ & $\begin{array}{l}\text { Low adsorption capacities (in flue gases } \\
\text { conditions) }\end{array}$ \\
\hline Cryogenic distillation & $\begin{array}{l}\text { (i) Liquid } \mathrm{CO}_{2} \text { production } \\
\text { (ii) Not requiring solvents or other } \\
\text { components } \\
\text { (iii) Easy scaled-up to industrial-scale } \\
\text { application }\end{array}$ & Require large amount of energy \\
\hline Membrane separation & $\begin{array}{l}\text { (i) Clean and simple process } \\
\text { (ii) Continuous, steady-state technology }\end{array}$ & $\begin{array}{l}\text { Require high energy for post-combustion } \\
\mathrm{CO}_{2} \text { capture }\end{array}$ \\
\hline
\end{tabular}

Improved polymeric membrane materials with superior separation performance can be obtained by synthesizing new polymers or modification or blending existing commercial polymers with organic or inorganic compounds [208, 224].

Due to high operating cost of membrane processes, it is necessary to perform more researches and studies about preparation of suitable membranes.

2.4.3. Mixed Matrix Membranes. Zeolites, carbon molecular sieves (CMS), and many polymeric materials offer attractive transport properties for $\mathrm{CO}_{2}$ separation. By mixing membrane material, excellent membrane with high performance for $\mathrm{CO}_{2}$ separation (selectivities of $\mathrm{CO}_{2} / \mathrm{N}_{2}=17.8-39.6$ ) can be prepared [200]. A group of scientists proposed the use of membrane based on polymer/immobilized liquid system especially polymerized ionic liquid membrane (PILM) or gelled ionic liquid membrane. ILMs consisting of aqueous solutions of $20 \%$ DEA immobilized in $25.4 \mu \mathrm{m}$ microporous polypropylene supports have low permeability and suitable selectivity (974 barrer, 276, resp.) in 2 atm at $298 \mathrm{~K}$ [225-228].

2.4.4. Hollow Fiber Membrane. Most industrially important membranes for gas separations are hollow fiber ones. Asymmetric hollow fiber membranes (such as polyvinylidene difluoride (PVDF)) with inner skinless structures are favourable for $\mathrm{CO}_{2}$ separation and absorption in gas-liquid membrane by low mass-transfer resistance and high permeability. In addition, this process can achieve significantly high adsorption efficiencies due to the much larger surface area for gasliquid interface than conventional gas absorption processes [206, 229-232].

According to data in Table 6, inorganic membranes have high permeability (about 150000 barrer) and low selectivity (about 15). Of course, some of inorganic membranes such as $\mathrm{Y}$ (FAU) with $\alpha-\mathrm{Al}_{2} \mathrm{O}_{3}$ support and chitosan group are highly selective for $\mathrm{CO}_{2} / \mathrm{N}_{2}$ separation (selectivity $(\alpha) \approx 100-$ $800)$. Among polymeric membranes, polyamines have high permeability and selectivity $\left(10^{6}\right.$ (barrer) and 980 , resp.), and the second FSCM membranes have high permeability and fine selectivity $\left(10^{5}\right.$ (barrer), 230, resp.). Other polymeric membrane groups are not selective for $\mathrm{CO}_{2} / \mathrm{N}_{2}$ separation, and maximum selectivity of these membranes is about 30 .

2.5. Novel $\mathrm{CO}_{2}$ Capture Technologies. These methods include electrochemical pumps and chemical looping approaches to $\mathrm{CO}_{2}$ separation. The molten carbonate and aqueous alkaline fuel cells have been studied for use in separating $\mathrm{CO}_{2}$ from both air and flue gases. Electrochemical pumps discussed include carbonate and proton conductors. Molten carbonate is nearly $100 \%$ selective for $\mathrm{CO}_{2}$ separation, but major disadvantage in the application of molten carbonate electrochemical cells for $\mathrm{CO}_{2}$ separation is that this process is not repeatedly. Other disadvantages of these technologies are: corrosion, difficult operating condition $(T=873 \mathrm{~K})$, and sensitivity to the presence of $\mathrm{SO}_{x}[45,233]$.

In chemical looping combustion, the oxygen for combustion of the fuel is provided by a regenerable metal oxide catalyst. The chemical looping scheme can be presented in the general form [45]:

$$
\begin{aligned}
& \mathrm{HC}+\text { metal oxide } \\
& \quad \longrightarrow \mathrm{CO}_{2}+\mathrm{H}_{2} \mathrm{O}+\text { lower oxide (and/or metal) } \\
& \text { lower oxide (and/or metal) }+\mathrm{O}_{2} \longrightarrow \text { metal oxide }
\end{aligned}
$$

Nickel oxide is one main candidate for the chemical looping combustion of methane, as low as $673 \mathrm{~K}$, because it is extensive and effective for the chemical looping combustion [45].

2.6. Discussion. Various technologies such as absorption, adsorption, cryogenic distillation, and membrane have been suggested for $\mathrm{CO}_{2}$ separation from flue gases (Table 7). In this paper, various technologies for different feed conditions were investigated. Absorption is an important technology for $\mathrm{CO}_{2}$ separation. Although physical solvents required low energy for regeneration, they have low absorption capacity and selectivity for $\mathrm{CO}_{2}$ separation. Selexol is the best physical solvent and suitable for sweetening natural gas. However, physical absorption is not economical for flue gas streams 
with $\mathrm{CO}_{2}$ concentration lower than 15 vol\% (95 US\$/ton $\mathrm{CO}_{2}$ [234]).

Chemical solvents are classified in main groups such as alkanolamines, ammonia, aqueous piperazine (PZ), and amino acids. Chemical absorbents such as monoethanolamine (MEA) have high absorption capacities and are very flexible for $\mathrm{CO}_{2}$ separation; therefore, these solvents are usually preferred to physical solvents. Chemical absorption with alkanolamines is the only technology that is used in an industrial scale for post-combustion capture. Amines react rapidly, selectively, and reversibly with $\mathrm{CO}_{2}$ and are relatively nonvolatile and inexpensive solvents. In this process, the corrosion is the main problem; therefore, in recent studies, new amines and various mixtures of them were proposed and compared with previous ones to find suitable solvents. Suitable solvents for $\mathrm{CO}_{2}$ separation must have high $\mathrm{CO}_{2}$ absorption capacity, less corrosion, less viscosity and less regeneration energy. These studies showed that CASTOR 1 and 2, which are blended amine solvents (MEA/MDEA), are the best chemical adsorbents so far proposed for postcombustion $\mathrm{CO}_{2}$ capture. Experimental results indicated that amine amino acid salts (AAAS) have better performance than MEA of the same concentration for $\mathrm{CO}_{2}$ absorption, but do not deteriorate in the presence of oxygen. However, absorption has several disadvantages such as it requires high energy to regenerate solvents $\left(3.0 \mathrm{GJ} /\right.$ ton $\mathrm{CO}_{2}$ for absorption with $40 \%$ wt MEA in $210 \mathrm{kPa}$ [235]), therefore need more efforts in the future to reduce energy consumption in postcombustion $\mathrm{CO}_{2}$ capture with chemical absorption.

Adsorption is the one effective technology that can reduce energy and cost of the capture or separation of $\mathrm{CO}_{2}$ in post-combustion capture. Adsorption is suitable for separating $\mathrm{CO}_{2}$ from dilute and low flow rate stream, but flue gases conditions are the main problem against industrialization adsorption process. The $\mathrm{CaO}-\mathrm{MgAl}_{2} \mathrm{O}_{4}$ and nano $\mathrm{CaO} / \mathrm{Al}_{2} \mathrm{O}_{3}$ are the best chemical adsorbents. Although, the chemical adsorbents have high capacity and selectivity, but their regeneration is difficult. Physical adsorption is the most suitable for $\mathrm{CO}_{2}$ capture at high pressures and low temperatures. At higher pressure (above 4 bar) activated carbons are more efficient than zeolites. The energy and cost of adsorption for activated carbons are nearly half of that of zeolites. On the other hand, zeolites (particularly 13X and 5A) have high selectivity for $\mathrm{CO}_{2}$ separation. Generally, zeolite $5 \mathrm{~A}$ may have better adsorption efficiency at co-adsorption of $\mathrm{SO}_{2}$, $\mathrm{NO}$ and $\mathrm{CO}_{2}$ than zeolite $13 \mathrm{X}$.

In order to achieve more selective $\mathrm{CO}_{2}$ separation from flue gases, the modified adsorbent surface was considered. New adsorbents such as honeyncomb monolith, MOFs, CHAs (NaCHA and CaCHA), PMO (MCM and SBA) and MSPs $\left(\mathrm{Na}_{2} \mathrm{SiO}_{4}\right)$ are suitable adsorbents for selective $\mathrm{CO}_{2}$ separation but they require more researches and studies. However, the development of suitable adsorbents with high $\mathrm{CO}_{2}$ adsorption capacity, which can be replaced absorption with chemical adsorbent, is still demanded.

Cryogenic distillation separation can be used for $\mathrm{CO}_{2}$ separation but its major disadvantage is the large amount of energy required to provide the refrigeration. Many new processes have been proposed for using cryogenic, but generally this technology is not suitable for post-combustion capture and is appropriate for oxy-fuel combustion method and $\mathrm{CO}_{2}$ separation from exhaust of cement industry (stream with high $\mathrm{CO}_{2}$ concentration).

The membrane separation method is a continuous, steady-state, clean and simple process for $\mathrm{CO}_{2}$ recovery. Since the pressure drop is driving force for membrane process, the flue gas stream must compress. Since compressing flue gas is very difficult and expensive, membrane separation is suitable for high pressure stream with high concentration (>10 vol\%). Inorganic membrane have high thermal and chemical stability but their selectivity is lower than polymeric membranes. Although $\mathrm{Y}$ (FAU) with $\alpha-\mathrm{Al}_{2} \mathrm{O}_{3}$ support and arginine salt chitosan are the best inorganic membrane, zeolite mambranes are suitable ones for $\mathrm{CO}_{2}$ separation. Polymeric membranes are very selective for $\mathrm{CO}_{2}$ separation but they have low thermal stability. Therefore, polymeric membranes are suitable for application in pre-combustion processes. Glassy polymeric membranes have higher selectivity, while the rubbery polymeric membranes have higher thermal stability. Perfect membrane with high performance for $\mathrm{CO}_{2}$ separation (selectivities of $\mathrm{CO}_{2} / \mathrm{N}_{2}=17.8-39.6$ ) can be prepared by mixing various membranes.

Because of operating problems and high cost of compressing, membrane separation is not suitable for post-combustion capture, but membrane technology is suitable for producing oxygen-enriched streams from air, in oxy-fuel combustion systems.

Electrochemical pumps and chemical looping are two new technologies suggested for $\mathrm{CO}_{2}$ capture. Now these technologies are not effective in comparison with other technologies. Therefore, application of electrochemical pumps and chemical looping in CCS needs more research.

\section{Conclusion}

Because of economical and environmental incentives, researchers have mainly focused on $\mathrm{CO}_{2}$ separation from different process streams, especially from the flue gases. In recent years, post-combustion capture has been the topic of many researches, because it is more flexible and can be easily added to the fossil fuel power plants.

Based on above findings, it can be concluded that flue gases properties (mainly concentration of $\mathrm{CO}_{2}$, temperature and pressure) are the most effective factors for selection of suitable process for $\mathrm{CO}_{2}$ separation.

Since flue gases have high temperature (about $373 \mathrm{~K}$ ), low pressure, and low $\mathrm{CO}_{2}$ concentration ( $1 \mathrm{~atm}$ and $10-15 \%$ $\mathrm{moL}$ ), bulk absorption and adsorption processes may be the best suitable process for $\mathrm{CO}_{2}$ separation from these streams. Due to simplicity of absorption process, this process has been applied in industrial plants, although many researches have been focused on preparation of adsorbents with high selectivity and capacity, in recent years. For industrial application, more studies about adsorbents are necessary. Cryogenic distillation and membrane processes are efficient for gas streams with high $\mathrm{CO}_{2}$ concentration. Therefore, these process are economically efficient for pre-combustion capture. In recent 
years, different studies have been performed to optimize cryogenic cycles and preparation of suitable membrane for $\mathrm{CO}_{2}$ separation from post-combustion flue gases.

By the result of this study, future research direction on the scale-up and industrialization of adsorption (with modified adsorbent), and membrane process for $\mathrm{CO}_{2}$ separation is suggested. Therefore more studies must be focused on modeling and simulation of these processes (membrane and adsorption), although research for finding new adsorbent, suitable mambrane (with mixed or modified present membrane) and blending amine solvents can reduce CCS cost.

\section{Conflict of Interests}

The authors declare that there is no conflict of interests regarding the publication of this paper.

\section{References}

[1] S. Q. Solomon, S. Q. D, M. Manning et al., "Book reviews," South African Geographical Journal, vol. 91, pp. 103-104, 2009.

[2] C. A. McMillan, G. A. Keoleian, and D. V. Spitzley, Greenhouse Gases, University of Michigan, Ann Arbor, Mich, USA , 2005.

[3] T. J. Blasing, Recent Greenhouse Gas Concentrations, US Department of Energy, 32 edition, 2012.

[4] C. H. Chiao, J. L. Chen, C. R. Lan, S. Chen, and H. W. Hsu, "Development of carbon dioxide capture and storage technology taiwan power company perspective," Sustainable Environment Research, vol. 21, pp. 1-8, 2011.

[5] T. L. P. Dantas, F. M. T. Luna, I. J. Silva et al., "Carbon dioxidenitrogen separation through pressure swing adsorption," Chemical Engineering Journal, vol. 172, no. 2-3, pp. 698-704, 2011.

[6] K. E. Zanganeh, A. Shafeen, and C. Salvador, " $\mathrm{CO}_{2}$ capture and development of an advanced pilot-scale cryogenic separation and compression unit," Energy Procedia, vol. 1, pp. 247-252, 2009.

[7] A. T. A. o.C.a.N.A.C.o, "Canadian aviation industry report on greenhouse gas emissions reductions," Tech. Rep., Ottawa, Canda, 2012.

[8] D. Berstad, R. Anantharaman, and P. Nekså, "Low-temperature $\mathrm{CO}_{2}$ capture technologies-applications and potential," International Journal of Refrigeration, vol. 36, pp. 1403-1416, 2013.

[9] I.E.A.I.G.G.R.D. Programme, " $\mathrm{CO}_{2}$ abatement in oil refineries: fired heaters," I. E. A. I.G.G.R.D, PH3/31 edition, 2000.

[10] L. Zhao, E. Riensche, R. Menzer, L. Blum, and D. Stolten, "A parametric study of $\mathrm{CO}_{2} / \mathrm{N}_{2}$ gas separation membrane processes for post-combustion capture," Journal of Membrane Science, vol. 325, no. 1, pp. 284-294, 2008.

[11] A. Hussain and M.-B. Hägg, "A feasibility study of $\mathrm{CO}_{2}$ capture from flue gas by a facilitated transport membrane," Journal of Membrane Science, vol. 359, no. 1-2, pp. 140-148, 2010.

[12] I. T. Forum, "Reducing transport greenhouse gas emissions: trends \& data," 2010.

[13] N. Mahasenan, S. Smith, K. Humphreys, and Y. Kaya, "The cement industry and global climate change: current and potential future cement industry $\mathrm{CO}_{2}$ emissions," in Proceedings of the Greenhouse Gas Control Technologies-6th International Conference, p. 995, Pergamon, Turkey, 2003.
[14] K. S. Lackner, A. H. A. Park, and B. G. Miller, "Eliminating $\mathrm{CO}_{2}$ emissions from coal-fired power plants," in Generating Electricity in a Carbon-Constrained World, pp. 127-173, Academic Press, Boston, 2010.

[15] A. Mohammadi, M. Soltanieh, M. Abbaspour, and F. Atabi, "What is energy efficiency and emission reduction potential in the Iranian petrochemical industry?" International Journal of Greenhouse Gas Control, vol. 12, pp. 460-471, 2013.

[16] E. Worrell, L. Price, N. Martin, C. Hendriks, and L. O. Meida, "Carbon dioxide emissions from the global cement industry," Annual Review of Energy and the Environment, vol. 26, pp. 303329, 2001.

[17] H. Yang, Z. Xu, M. Fan et al., "Progress in carbon dioxide separation and capture: a review," Journal of Environmental Sciences, vol. 20, no. 1, pp. 14-27, 2008.

[18] J. Barnett, S. Dessai, and M. Webber, "Will OPEC lose from the Kyoto Protocol?” Energy Policy, vol. 32, no. 18, pp. 2077-2088, 2004.

[19] H. Li, R. P. Berrens, A. K. Bohara, H. C. Jenkins-Smith, C. L. Silva, and D. L. Weimer, "Would developing country commitments affect US households' support for a modified Kyoto Protocol?" Ecological Economics, vol. 48, no. 3, pp. 329-343, 2004.

[20] M. Crombie, S. Imbus, and I. Miracca, " $\mathrm{CO}_{2}$ capture project phase 3-demonstration phase," Energy Procedia, vol. 4, pp. 6104-6108, 2011.

[21] U. Springer, "The market for tradable GHG permits under the Kyoto Protocol: a survey of model studies," Energy Economics, vol. 25, no. 5, pp. 527-551, 2003.

[22] A. Pridmore, A. Bristow, T. May, and M. Tight, "Climate change, impacts, future scenarios and the role of transport," Report of University of Leeds, Institute for Transport Studies, 2003.

[23] J. G. J. Olivier, G. Janssens-Maenhout, and J. A. H. W. Peters, "Trends in global $\mathrm{CO}_{2}$ emissions," Tech. Rep., PBL Netherlands Environmental Assessment Agency, Ispra, Italy, 2012.

[24] H. Herzog, J. Meldon, and A. Hatton, "Advanced post-combustion $\mathrm{CO}_{2}$ capture," Tech. Rep., Clean Air Task Force, Doris Duke Foundation, 2009.

[25] J. C. M. Pires, F. G. Martins, M. C. M. Alvim-Ferraz, and M. Simões, "Recent developments on carbon capture and storage: an overview," Chemical Engineering Research and Design, vol. 89, no. 9, pp. 1446-1460, 2011.

[26] D. G. Chapel, C. L. Mariz, and J. Ernest, "Recovery of $\mathrm{CO}_{2}$ from flue gases: commercial trends," in Proceedings of the Canadian Society of Chemical Engineers Annual Meeting, pp. 1-16, 1999.

[27] F. T. Zangeneh, S. Sahebdelfar, and M. T. Ravanchi, "Conversion of carbon dioxide to valuable petrochemicals: an approach to clean development mechanism," Journal of Natural Gas Chemistry, vol. 20, no. 3, pp. 219-231, 2011.

[28] N. Dave, T. Do, G. Puxty, R. Rowland, P. H. M. Feron, and M. I. Attalla, " $\mathrm{CO}_{2}$ capture by aqueous amines and aqueous ammonia-A Comparison," Energy Procedia, vol. 1, pp. 949-954, 2009.

[29] R. Thiruvenkatachari, S. Su, H. An, and X. X. Yu, "Post combustion $\mathrm{CO}_{2}$ capture by carbon fibre monolithic adsorbents," Progress in Energy and Combustion Science, vol. 35, no. 5, pp. 438-455, 2009.

[30] J. Gibbins and H. Chalmers, "Carbon capture and storage," Energy Policy, vol. 36, no. 12, pp. 4317-4322, 2008.

[31] B. Metz, “Carbon Dioxide Capture and Storage:" Special Report of the Intergovernmental Panel on Climate Change, 2005. 
[32] T. F. Wall, "Combustion processes for carbon capture," Proceedings of the Combustion Institute, vol. 31, pp. 31-47, 2007.

[33] E. Rubin and H. de Coninck, "IPCC special report on carbon dioxide capture and storage," Tech. Rep., Cambridge University Press, UK, 2005, TNO, Cost Curves for $\mathrm{CO}_{2}$ Storage, part 2, 2004.

[34] V. R. Choudhary, S. Mayadevi, and A. P. Singh, "Sorption isotherms of methane, ethane, ethene and carbon dioxide on $\mathrm{NaX}, \mathrm{NaY}$ and Na-mordenite zeolites," Journal of the Chemical Society, Faraday Transactions, vol. 91, no. 17, pp. 2935-2944, 1995.

[35] P. Dechamps, "European $\mathrm{CO}_{2}$ capture and storage projects," Tech. Rep., European Commission, Brussels, Belgium, 2007.

[36] B. J. P. Buhre, L. K. Elliott, C. D. Sheng, R. P. Gupta, and T. F. Wall, "Oxy-fuel combustion technology for coal-fired power generation," Progress in Energy and Combustion Science, vol. 31, no. 4, pp. 283-307, 2005.

[37] M. Glazer, C. Bertrand, L. Fryda, and W. de Jong, "EOSLT consortium biomass co-firing, WP 4-biomass co-firing in oxyfuel combustion Part II: ash deposition modelling of coal and biomass blends under air and oxygen combustion conditions," Tech. Rep., Energy research Center of the Neterland, 2010.

[38] SAGE Publications, I. Green Issues and Debates: an A-to-Z Guide. Green Issues and Debates: an A-to-Z Guide, SAGE Publications, Oaks, Calif, USA.

[39] A. A. Olajire, " $\mathrm{CO}_{2}$ capture and separation technologies for endof-pipe applications-a review," Energy, vol. 35, no. 6, pp. 26102628, 2010.

[40] A. Samanta, A. Zhao, G. K. H. Shimizu, P. Sarkar, and R. Gupta, "Post-combustion $\mathrm{CO}_{2}$ capture using solid sorbents: a review," Industrial and Engineering Chemistry Research, vol. 51, no. 4, pp. 1438-1463, 2012.

[41] J. S. Rhodes and D. W. Keith, "Engineering economic analysis of biomass IGCC with carbon capture and storage," Biomass and Bioenergy, vol. 29, no. 6, pp. 440-450, 2005.

[42] T. L. Dantas, A. E. Rodrigues, and R. F. Moreira, "Separation of carbon dioxide from flue gas using adsorption on porous solids," Tech: Greenhouse Gases-Capturing, Utilization and Reduction, 2012.

[43] G. S. Esber III, "Carbon dioxide capture technology for the coal-powered electricity industry: a systematic prioritization of research needs," Tech. Rep., Massachusetts Institute of Technology, 2006.

[44] Y. Lv, X. Yu, J. Jia, S.-T. Tu, J. Yan, and E. Dahlquist, "Fabrication and characterization of superhydrophobic polypropylene hollow fiber membranes for carbon dioxide absorption," Applied Energy, vol. 90, no. 1, pp. 167-174, 2012.

[45] E. J. Granite and T. O’Brien, "Review of novel methods for carbon dioxide separation from flue and fuel gases," Fuel Processing Technology, vol. 86, no. 14-15, pp. 1423-1434, 2005.

[46] T. Nguyen, M. Hilliard, and G. T. Rochelle, "Amine volatility in $\mathrm{CO}_{2}$ capture," International Journal of Greenhouse Gas Control, vol. 4, no. 5, pp. 707-715, 2010.

[47] M. Gupta, I. Coyle, and K. Thambimuthu, "CO2capture technologies and opportunities in Canada," in Proceedings of the 1st Canadian CC\&S Technology Roadmap Workshop CO2 capture technologies and opportunities in Canada, CANMET Energy Technology Centre Natural Resources Canada, 2003.

[48] H. J. Herzog, "The economics of $\mathrm{CO}_{2}$ separation and capture," Journal of the Franklin Institute, vol. 7, pp. 13-24, 2000.
[49] G. Pellegrini, R. Strube, and G. Manfrida, "Comparative study of chemical absorbents in postcombustion $\mathrm{CO}_{2}$ capture," Energy, vol. 35, no. 2, pp. 851-857, 2010.

[50] N. MacDowell, N. Florin, A. Buchard et al., "An overview of $\mathrm{CO}_{2}$ capture technologies," Energy and Environmental Science, vol. 3, no. 11, pp. 1645-1669, 2010.

[51] X. P. Li Gang, A. Webley Paul, Zhang Jun, and R. Singh, "Competition of $\mathrm{CO}_{2} / \mathrm{H}_{2} \mathrm{O}$ in adsorption based $\mathrm{CO}_{2}$ capture," Energy Procedia, vol. 1, pp. 1123-1130.

[52] P. Singh, J. P. M. Niederer, and G. F. Versteeg, "Structure and activity relationships for amine based $\mathrm{CO}_{2}$ absorbents-I," International Journal of Greenhouse Gas Control, vol. 1, no. 1, pp. 5-10, 2007.

[53] S. Ma'mun, "Selection and characterization of new absorbents for carbon dioxide capture," in Chemical Engineering, Faculty of Natural Science and Technology, 2005.

[54] S. Cavenati, C. A. Grande, and A. E. Rodrigues, "Removal of carbon dioxide from natural gas by vacuum pressure swing adsorption," Energy and Fuels, vol. 20, no. 6, pp. 2648-2659, 2006.

[55] J. David, Economic evaluation of leading technology options 23 for sequestration of carbon dioxide [M.S. thesis], Chemical Engineering Practice Massachusetts Institute of Technology, 2000.

[56] D. L. Albritton, T. Barker, I. A. Bashmakov et al., Climate Change 2001: Synthesis Report, edited by D. J. Dokken, M. Noguer, ,P. V. d Linden,C. Johnson, J. Pan, Cambridge University Press, 2001.

[57] M. Wang, A. Lawal, P. Stephenson, J. Sidders, and C. Ramshaw, "Post-combustion $\mathrm{CO}_{2}$ capture with chemical absorption: a state-of-the-art review," Chemical Engineering Research and Design, vol. 89, no. 9, pp. 1609-1624, 2011.

[58] J. Gabrielsen, H. F. Svendsen, M. L. Michelsen, E. H. Stenby, and G. M. Kontogeorgis, "Experimental validation of a ratebased model for $\mathrm{CO}_{2}$ capture using an AMP solution," Chemical Engineering Science, vol. 62, no. 9, pp. 2397-2413, 2007.

[59] R. Idem, M. Wilson, P. Tontiwachwuthikul et al., "Pilot plant studies of the $\mathrm{CO}_{2}$ capture performance of aqueous MEA and mixed MEA/MDEA solvents at the University of Regina $\mathrm{CO}_{2}$ capture technology development plant and the boundary dam $\mathrm{CO}_{2}$ capture demonstration plant," Industrial and Engineering Chemistry Research, vol. 45, no. 8, pp. 2414-2420, 2006.

[60] M. Lucquiaud and J. Gibbins, "On the integration of $\mathrm{CO}_{2}$ capture with coal-fired power plants: a methodology to assess and optimise solvent-based post-combustion capture systems," Chemical Engineering Research and Design, vol. 89, no. 9, pp. 1553-1571, 2011.

[61] J. N. Knudsen, J. N. Jensen, P. J. Vilhelmsen, and O. Biede, "Experience with $\mathrm{CO}_{2}$ capture from coal flue gas in pilot-scale: testing of different amine solvents," Energy Procedia, vol. 1, no. 1, pp. 783-790, 2009.

[62] P. H. M. Feron, "Exploring the potential for improvement of the energy performance of coal fired power plants with postcombustion capture of carbon dioxide," International Journal of Greenhouse Gas Control, vol. 4, no. 2, pp. 152-160, 2010.

[63] F. Qin, S. Wang, A. Hartono, H. F. Svendsen, and C. Chen, "Kinetics of $\mathrm{CO}_{2}$ absorption in aqueous ammonia solution," International Journal of Greenhouse Gas Control, vol. 4, no. 5, pp. 729-738, 2010.

[64] H. P. Mangalapally, R. Notz, S. Hoch et al., "Pilot plant experimental studies of post combustion $\mathrm{CO}_{2}$ capture by reactive absorption with MEA and new solvents," Energy Procedia, vol. 1, pp. 963-970, 2009. 
[65] P. S. Kumar, J. A. Hogendoorn, G. F. Versteeg, and P. H. M. Feron, "Kinetics of the reaction of $\mathrm{CO}_{2}$ with aqueous potassium salt of taurine and glycine," AIChE Journal, vol. 49, no. 1, pp. 203-213, 2003.

[66] S. A. Freeman, R. Dugas, D. van Wagener, T. Nguyen, and G. T. Rochelle, "Carbon dioxide capture with concentrated, aqueous piperazine," Energy Procedia, vol. 1, pp. 1489-1496, 2009.

[67] J. V. Holst, G. F. Versteeg, D. W. F. Brilman, and J. A. Hogendoorn, "Kinetic study of $\mathrm{CO}_{2}$ with various amino acid salts in aqueous solution," Chemical Engineering Science, vol. 64, no. 1, pp. 59-68, 2009.

[68] E. S. Hamborg, J. P. M. Niederer, and G. F. Versteeg, "Dissociation constants and thermodynamic properties of amino acids used in $\mathrm{CO}_{2}$ absorption from (293 to 353) K," Journal of Chemical and Engineering Data, vol. 52, no. 6, pp. 2491-2502, 2007.

[69] U. E. Aronu, H. F. Svendsen, and K. A. Hoff, "Investigation of amine amino acid salts for carbon dioxide absorption," International Journal of Greenhouse Gas Control, vol. 4, no. 5, pp. 771-775, 2010.

[70] J. T. Yeh, K. P. Resnik, K. Rygle, and H. W. Pennline, "Semibatch absorption and regeneration studies for $\mathrm{CO}_{2}$ capture by aqueous ammonia," Fuel Processing Technology, vol. 86, no. 1415, pp. 1533-1546, 2005.

[71] C. H. Yu, C. H. Huang, and C. S. Tan, "A Review of $\mathrm{CO}_{2}$ Capture by Absorption and Adsorption," Aerosol and Air Quality Research, vol. 12, pp. 745-769, 2012.

[72] B. E. Gurkan, C. Juan, E. M. Mindrup et al., "Chemically complexing ionic liquids for post-combustion $\mathrm{CO}_{2}$ capture," in Clearwater Clean Coal Conference, pp. 6-10, Clearwater, Fla, USA, 2010.

[73] E. D. Bates, R. D. Mayton, I. Ntai, and J. H. Davis Jr., " $\mathrm{CO}_{2}$ capture by a task-specific ionic liquid," Journal of the American Chemical Society, vol. 124, no. 6, pp. 926-927, 2002.

[74] S. Baj, A. Siewniak, A. Chrobok, T. Krawczyk, and A. Sobolewski, "Monoethanolamine and ionic liquid aqueous solutions as effective systems for $\mathrm{CO}_{2}$ capture," Journal of Chemical Technology and Biotechnology, vol. 88, pp. 1220-1227, 2012.

[75] J. P. Ciferno, D. Lang, and G. T. Rochelle, Carbon Dioxide Capture by Absorption with Potassium Carbonate, University of Texas, 2010.

[76] J. T. Cullinane and G. T. Rochelle, "Thermodynamics of aqueous potassium carbonate, piperazine, and carbon dioxide," Fluid Phase Equilibria, vol. 227, no. 2, pp. 197-213, 2005.

[77] H. P. Mangalapally and H. Hasse, "Pilot plant experiments with mea and new solvents for post combustion $\mathrm{CO}_{2}$ capture by reactive absorption," Energy Procedia, vol. 4, pp. 1-8, 2011.

[78] J. Brouwer, P. Feron, and N. Ten Asbroek, "Amino-acid salts for $\mathrm{CO}_{2}$ capture from flue gases," in Proceedings of the 4th Annual Conference on Carbon Capture \& Sequestration, 2009.

[79] D. Kang, S. Park, H. Jo, J. Min, and J. Park, "Solubility of $\mathrm{CO}_{2}$ in amino-acid-based solutions of (potassium sarcosinate), (potassium alaninate + piperazine), and (potassium serinate + piperazine)," Journal of Chemical \& Engineering Data, vol. 58, pp. 1787-1791, 2013.

[80] B. Farid and E. Fadwa, "Front matter," in Proceedings of the 2nd Annual Gas Processing Symposium, p. 488, Elsevier, Doha, Qatar, 2010.

[81] R. M. Davidson, Post-Combustion Carbon Capture from Coal Fired Plants: Solvent Scrubbing, IEA Clean Coal Centre, 2007.
[82] V. Darde, K. Thomsen, W. J. van Well, and E. H. Stenby, "Chilled ammonia process for $\mathrm{CO}_{2}$ capture," Energy Procedia, vol. 1, pp. 1035-1042, 2009.

[83] S. Bishnoi and G. T. Rochelle, "Thermodynamics of piperazine/methyldiethanolamine/water/carbon dioxide," Industrial and Engineering Chemistry Research, vol. 41, no. 3, pp. 604-612, 2002.

[84] A. Bajpai and M. K. Mondal, "Equilibrium solubility of $\mathrm{CO}_{2}$ in aqueous mixtures of DEA and AEEA," Journal of Chemical \& Engineering Data, vol. 58, pp. 1490-1495, 2013.

[85] A. L. Chaffee, G. P. Knowles, Z. Liang, J. Zhang, P. Xiao, and P. A. Webley, " $\mathrm{CO}_{2}$ capture by adsorption: materials and process development," International Journal of Greenhouse Gas Control, vol. 1, no. 1, pp. 11-18, 2007.

[86] J.-R. Li, Y. Ma, M. C. McCarthy et al., "Carbon dioxide capture-related gas adsorption and separation in metal-organic frameworks," Coordination Chemistry Reviews, vol. 255, no. 1516, pp. 1791-1823, 2011.

[87] L.-Y. Meng and S.-J. Park, "Influence of MgO template on carbon dioxide adsorption of cation exchange resin-based nanoporous carbon," Journal of Colloid and Interface Science, vol. 366, no. 1, pp. 135-140, 2012.

[88] M. Sevilla and A. B. Fuertes, " $\mathrm{CO}_{2}$ adsorption by activated templated carbons," Journal of Colloid and Interface Science, vol. 366, no. 1, pp. 147-154, 2012.

[89] M. Martunus, Z. Helwani, A. D. Wiheeb, J. Kim, and M. R. Othman, "Improved carbon dioxide capture using metal reinforced hydrotalcite under wet conditions," International Journal of Greenhouse Gas Control, vol. 7, pp. 127-136, 2012.

[90] B. Dou, Y. Song, Y. Liu, and C. Feng, "High temperature $\mathrm{CO}_{2}$ capture using calcium oxide sorbent in a fixed-bed reactor," Journal of Hazardous Materials, vol. 183, no. 1-3, pp. 759-765, 2010.

[91] M. Kotyczka-moranska, G. Tomaszewicz, and G. Labojko, "Comparison of different methods for enhancing $\mathrm{CO}_{2}$ capture by $\mathrm{CaO}$-based sorbents. Review," Physicochemical Problems of Mineral Processing, vol. 48, pp. 77-90, 2012.

[92] G. Valenti, D. Bonalumi, and E. Macchi, "A parametric investigation of the chilled ammonia process from energy and economic perspectives," Fuel, vol. 101, pp. 74-83, 2011.

[93] Z. H. Lee, K. T. Lee, S. Bhatia, and A. R. Mohamed, "Postcombustion carbon dioxide capture: evolution towards utilization of nanomaterials," Renewable and Sustainable Energy Reviews, vol. 16, no. 5, pp. 2599-2609, 2012.

[94] Z. Xiang, Z. Hu, D. Cao et al., "Metal-organic frameworks with incorporated carbon nanotubes: improving carbon dioxide and methane storage capacities by lithium doping," Angewandte Chemie, vol. 50, no. 2, pp. 491-494, 2011.

[95] K. Essaki, M. Kato, and K. Nakagawa, " $\mathrm{CO}_{2}$ removal at high temperature using packed bed of lithium silicate pellets," Journal of the Ceramic Society of Japan, vol. 114, no. 1333, pp. 739-742, 2006.

[96] C. S. Martavaltzi and A. A. Lemonidou, "Development of new $\mathrm{CaO}$ based sorbent materials for $\mathrm{CO}_{2}$ removal at high temperature," Microporous and Mesoporous Materials, vol. 110, no. 1, pp. 119-127, 2008.

[97] R. Besson, M. Rocha Vargas, and L. Favergeon, " $\mathrm{CO}_{2}$ adsorption on calcium oxide: an atomic-scale simulation study," Surface Science, vol. 606, no. 3-4, pp. 490-495, 2012.

[98] S. Miyata, "Anion-exchange properties of hydrotalcite-like compounds," Clays \& Clay Minerals, vol. 31, no. 4, pp. 305-311, 1983. 
[99] A. R. Mohamed, S. Bhatia, K. T. Lee, C. Y. H. Foo, Z. H. Lee, and N. A. Razali, "Nanomaterials as environmentally compatible next generation green carbon capture and utilization materials," Transactions on GIGAKU, vol. 1, Article ID 01006, pp. 1-7, 2012.

[100] M. Songolzadeh, M. Takht Ravanchi, and M. Soleimani, "Carbon dioxide capture and storage: a general review on adsorbents," World Academy of Science, Engineering and Technology, vol. 70, pp. 225-232, 2012.

[101] M. Anbia and V. Hoseini, "Development of MWCNT@MIL101 hybrid composite with enhanced adsorption capacity for carbon dioxide," Chemical Engineering Journal, vol. 191, pp. 326330, 2012.

[102] L.-Y. Lin and H. Bai, "Continuous generation of mesoporous silica particles via the use of sodium metasilicate precursor and their potential for $\mathrm{CO}_{2}$ capture," Microporous and Mesoporous Materials, vol. 136, no. 1-3, pp. 25-32, 2010.

[103] D. M. D’Alessandro, B. Smit, and J. R. Long, "Carbon dioxide capture: prospects for new materials," Angewandte Chemie, vol. 49, no. 35, pp. 6058-6082, 2010.

[104] D. I. Jang and S. J. Park, "Influence of nickel oxide on carbon dioxide adsorption behaviors of activated carbons," Fuel, vol. 102, pp. 439-444, 2012.

[105] S. Choi, J. H. Drese, and C. W. Jones, "Adsorbent materials for carbon dioxide capture from large anthropogenic point sources," ChemSusChem, vol. 2, no. 9, pp. 796-854, 2009.

[106] J. A. Delgado, M. A. Uguina, J. L. Sotelo, and B. Ruíz, "Fixedbed adsorption of carbon dioxide-helium, nitrogen-helium and carbon dioxide-nitrogen mixtures onto silicalite pellets," Separation and Purification Technology, vol. 49, no. 1, pp. 91-100, 2006.

[107] H. R. Abid, G. H. Pham, H.-M. Ang, M. O. Tade, and S. Wang, "Adsorption of $\mathrm{CH}_{4}$ and $\mathrm{CO}_{2}$ on $\mathrm{Zr}$-metal organic frameworks," Journal of Colloid and Interface Science, vol. 366, no. 1, pp. 120124, 2012.

[108] J. Wang, L. A. Stevens, T. C. Drage, and J. Wood, "Preparation and $\mathrm{CO}_{2}$ adsorption of amine modified $\mathrm{Mg}-\mathrm{Al} \mathrm{LDH}$ via exfoliation route," Chemical Engineering Science, vol. 68, no. 1, pp. 424-431, 2012.

[109] A. K. Mishra and S. Ramaprabhu, "Palladium nanoparticles decorated graphite nanoplatelets for room temperature carbon dioxide adsorption," Chemical Engineering Journal, vol. 187, pp. 10-15, 2012.

[110] G. Finos, S. Collins, G. Blanco et al., "Infrared spectroscopic study of carbon dioxide adsorption on the surface of ceriumgallium mixed oxides," Catalysis Today, vol. 180, no. 1, pp. 9-18, 2012.

[111] R. P. Grimm, K. A. Eriksson, N. Ripepi, C. Eble, and S. F. Greb, "Seal evaluation and confinement screening criteria for beneficial carbon dioxide storage with enhanced coal bed methane recovery in the Pocahontas Basin, Virginia," International Journal of Coal Geology, vol. 90-91, pp. 110-125, 2012.

[112] B. Guo, L. Chang, and K. Xie, "Adsorption of carbon dioxide on activated carbon," Journal of Natural Gas Chemistry, vol. 15, no. 3, pp. 223-229, 2006.

[113] R. Sakurovs, S. Day, and S. Weir, "Relationships between the sorption behaviour of methane, carbon dioxide, nitrogen and ethane on coals," Fuel, vol. 97, pp. 725-729, 2012.

[114] P. Weniger, J. Franců, P. Hemza, and B. M. Krooss, "Investigations on the methane and carbon dioxide sorption capacity of coals from the SW Upper Silesian Coal Basin, Czech Republic," International Journal of Coal Geology, vol. 93, pp. 23-39, 2012.
[115] C. Garnier, G. Finqueneisel, T. Zimny et al., "Selection of coals of different maturities for $\mathrm{CO}_{2}$ Storage by modelling of $\mathrm{CH}_{4}$ and $\mathrm{CO}_{2}$ adsorption isotherms," International Journal of Coal Geology, vol. 87, no. 2, pp. 80-86, 2011.

[116] J. C. Abanades, E. S. Rubin, and E. J. Anthony, "Sorbent cost and performance in $\mathrm{CO}_{2}$ capture systems," Industrial and Engineering Chemistry Research, vol. 43, no. 13, pp. 3462-3466, 2004.

[117] T. C. Drage, J. M. Blackman, C. Pevida, and C. E. Snape, "Evaluation of activated carbon adsorbents for $\mathrm{CO}_{2}$ capture in gasification," Energy and Fuels, vol. 23, no. 5, pp. 2790-2796, 2009.

[118] W. Shen, S. Zhang, Y. He, J. Li, and W. Fan, "Hierarchical porous polyacrylonitrile-based activated carbon fibers for $\mathrm{CO}_{2}$ capture," Journal of Materials Chemistry, vol. 21, no. 36, pp. 14036-14040, 2011.

[119] M. Gray, Y. Soong, K. Champagne, R. Stevens Jr, P. Toochinda, and S. Chuang, "Solid amine CO2capture sorbents," Fuel, vol. 80, pp. 867-871, 2001.

[120] C. Pevida, M. G. Plaza, B. Arias, J. Fermoso, F. Rubiera, and J. J. Pis, "Surface modification of activated carbons for $\mathrm{CO}_{2}$ capture," Applied Surface Science, vol. 254, no. 22, pp. 7165-7172, 2008.

[121] M. G. Plaza, C. Pevida, B. Arias, J. Fermoso, F. Rubiera, and J. J. Pis, "A comparison of two methods for producing $\mathrm{CO}_{2}$ capture adsorbents," Energy Procedia, vol. 1, pp. 1107-1113, 2009.

[122] M. G. Plaza, S. García, F. Rubiera, J. J. Pis, and C. Pevida, "Postcombustion $\mathrm{CO}_{2}$ capture with a commercial activated carbon: comparison of different regeneration strategies," Chemical Engineering Journal, vol. 163, no. 1-2, pp. 41-47, 2010.

[123] K. S. Nor Kamarudin and H. Mat, "Synthesis and modification of micro and mesoporous materials as $\mathrm{CO}_{2}$ adsorbent," Tech. Rep., Faculty of Chemical and Natural Resources Engineering: University of Technology, Johor, Malaysia, 2009.

[124] M. Radosz, X. Hu, K. Krutkramelis, and Y. Shen, "Flue-gas carbon capture on carbonaceous sorbents: toward a low-cost multifunctional carbon filter for "green" energy producers," Industrial and Engineering Chemistry Research, vol. 47, no. 10, pp. 3783-3794, 2008.

[125] J. M. Rosas, J. Bedia, J. Rodríguez-Mirasol, and T. Cordero, "Preparation of hemp-derived activated carbon monoliths. Adsorption of water vapor," Industrial and Engineering Chemistry Research, vol. 47, no. 4, pp. 1288-1296, 2008.

[126] R. Yang, G. Liu, M. Li, J. Zhang, and X. Hao, "Preparation and $\mathrm{N} 2, \mathrm{CO}_{2}$ and $\mathrm{H}_{2}$ adsorption of super activated carbon derived from biomass source hemp (Cannabis sativa L.) stem," Microporous and Mesoporous Materials, vol. 158, pp. 108-116, 2012.

[127] R. V. Siriwardane, M.-S. Shen, E. P. Fisher, and J. A. Poston, "Adsorption of $\mathrm{CO}_{2}$ on molecular sieves and activated carbon," Energy and Fuels, vol. 15, no. 2, pp. 279-284, 2001.

[128] K. I. Vatalis, A. Laaksonen, G. Charalampides, and N. P. Benetis, "Intermediate technologies towards low-carbon economy. the Greek zeolite CCS outlook into the EU commitments," Renewable and Sustainable Energy Reviews, vol. 16, no. 5, pp. 33913400, 2012.

[129] Z. Liu, C. A. Grande, P. Li, J. Yu, and A. E. Rodrigues, "Multi-bed vacuum pressure swing adsorption for carbon dioxide capture from flue gas," Separation and Purification Technology, vol. 81, pp. 307-317, 2011.

[130] J. Zhang, P. Xiao, G. Li, and P. A. Webley, "Effect of flue gas impurities on $\mathrm{CO}_{2}$ capture performance from flue gas at 
coal-fired power stations by vacuum swing adsorption," Energy Procedia, vol. 1, pp. 1115-1122, 2009.

[131] X. Cui, R. M. Bustin, and G. Dipple, "Selective transport of $\mathrm{CO}_{2}$, $\mathrm{CH}_{4}$, and $\mathrm{N}_{2}$ in coals: insights from modeling of experimental gas adsorption data," Fuel, vol. 83, no. 3, pp. 293-303, 2004.

[132] C. J. Anderson, W. Tao, J. Jiang, S. I. Sandler, G. W. Stevens, and S. E. Kentish, "An experimental evaluation and molecular simulation of high temperature gas adsorption on nanoporous carbon," Carbon, vol. 49, no. 1, pp. 117-125, 2011.

[133] M. Kumar and Y. Ando, "Chemical vapor deposition of carbon nanotubes: a review on growth mechanism and mass production," Journal of Nanoscience and Nanotechnology, vol. 10, no. 6, pp. 3739-3758, 2010.

[134] M. Cinke, J. Li, C. W. Bauschlicher Jr., A. Ricca, and M. Meyyappan, " $\mathrm{CO}_{2}$ adsorption in single-walled carbon nanotubes," Chemical Physics Letters, vol. 376, no. 5-6, pp. 761-766, 2003.

[135] A. F. Portugal, P. W. J. Derks, G. F. Versteeg, F. D. Magalhães, and A. Mendes, "Characterization of potassium glycinate for carbon dioxide absorption purposes," Chemical Engineering Science, vol. 62, no. 23, pp. 6534-6547, 2007.

[136] R. Banerjee, A. Phan, B. Wang et al., "High-throughput synthesis of zeolitic imidazolate frameworks and application to $\mathrm{CO}_{2}$ capture," Science, vol. 319, no. 5865, pp. 939-943, 2008.

[137] K. S. Park, Z. Ni, A. P. Côté et al., "Exceptional chemical and thermal stability of zeolitic imidazolate frameworks," Proceedings of the National Academy of Sciences of the United States of America, vol. 103, no. 27, pp. 10186-10191, 2006.

[138] T. D. Burchell and R. R. Judkins, "Passive $\mathrm{CO}_{2}$ removal using a carbon fiber composite molecular sieve," Energy Conversion and Management, vol. 37, no. 6-8, pp. 947-954, 1996.

[139] Z. Yong, V. Mata, and A. E. Rodrigues, "Adsorption of carbon dioxide at high temperature-a review," Separation and Purification Technology, vol. 26, no. 2-3, pp. 195-205, 2002.

[140] G. M. Kimber, M. Jagtoyen, Y. Q. Fei, and F. J. Derbyshire, "Fabrication of carbon fibre composites for gas separation," Gas Separation and Purification, vol. 10, no. 2, pp. 131-136, 1996.

[141] L. M. Viculis, J. J. Mack, O. M. Mayer, H. T. Hahn, and R. B. Kaner, "Intercalation and exfoliation routes to graphite nanoplatelets," Journal of Materials Chemistry, vol. 15, no. 9, pp. 974-978, 2005.

[142] A. K. Mishra and S. Ramaprabhu, "Study of $\mathrm{CO}_{2}$ adsorption in low cost graphite nanoplatelets," International Journal of Chemical Engineering and Applications, vol. 1, pp. 266-269, 2010.

[143] R. Du, X. Feng, and A. Chakma, "Poly(N,Ndimethylaminoethyl methacrylate)/polysulfone composite membranes for gas separations," Journal of Membrane Science, vol. 279, no. 1-2, pp. 76-85, 2006.

[144] K. Kumar, C. N. Dasgupta, B. Nayak, P. Lindblad, and D. Das, "Development of suitable photobioreactors for $\mathrm{CO}_{2}$ sequestration addressing global warming using green algae and cyanobacteria," Bioresource Technology, vol. 102, no. 8, pp. 49454953, 2011.

[145] H. Deng, H. Yi, X. Tang, Q. Yu, P. Ning, and L. Yang, "Adsorption equilibrium for sulfur dioxide, nitric oxide, carbon dioxide, nitrogen on 13X and 5A zeolites," Chemical Engineering Journal, vol. 188, pp. 77-85, 2012.

[146] N. Gargiulo, F. Pepe, and D. Caputo, "Modeling carbon dioxide adsorption on polyethylenimine-functionalized TUD-1 mesoporous silica," Journal of Colloid and Interface Science, vol. 367, no. 1, pp. 348-354, 2012.
[147] A. R. Millward and O. M. Yaghi, "Metal-organic frameworks with exceptionally high capacity for storage of carbon dioxide at room temperature," Journal of the American Chemical Society, vol. 127, no. 51, pp. 17998-17999, 2005.

[148] C. Lu, H. Bai, F. Su, W. Chen, J. F. Hwang, and H.-H. Lee, "Adsorption of carbon dioxide from gas streams via mesoporous spherical-silica particles," Journal of the Air and Waste Management Association, vol. 60, no. 4, pp. 489-496, 2010.

[149] A. Boonpoke, S. Chiarakorn, N. Laosiripojana, S. Towprayoon, and A. Chidthaisong, "synthesis of activated carbon and MCM41 from bagasse and rice husk and their carbon dioxide adsorption capacity," Journal of Sustainable Energy \& Environmentn, vol. 2, pp. 77-81, 2011.

[150] J. Wei, L. Liao, Y. Xiao, P. Zhang, and Y. Shi, "Capture of carbon dioxide by amine-impregnated as-synthesized MCM41," Journal of Environmental Sciences, vol. 22, no. 10, pp. 1558$1563,2010$.

[151] Q. Wang, H. H. Tay, Z. Zhong, J. Luo, and A. Borgna, "Synthesis of high-temperature $\mathrm{CO}_{2}$ adsorbents from organo-layered double hydroxides with markedly improved $\mathrm{CO}_{2}$ capture capacity," Energy \& Environmental Science, vol. 5, pp. 7526-7530, 2012.

[152] H. Lin and B. D. Freeman, "Gas solubility, diffusivity and permeability in poly(ethylene oxide)," Journal of Membrane Science, vol. 239, no. 1, pp. 105-117, 2004.

[153] P. Chowdhury, C. Bikkina, and S. Gumma, "Gas adsorption properties of the chromium-based metal organic framework MIL-101," The Journal of Physical Chemistry C, vol. 113, no. 16, pp. 6616-6621, 2009.

[154] P. Li, B. Ge, S. Zhang, S. Chen, Q. Zhang, and Y. Zhao, " $\mathrm{CO}_{2}$ capture by polyethylenimine-modified fibrous adsorbent," Langmuir, vol. 24, no. 13, pp. 6567-6574, 2008.

[155] B. Aziz, N. Hedin, and Z. Bacsik, "Quantification of chemisorption and physisorption of carbon dioxide on porous silica modified by propylamines: effect of amine density," Microporous and Mesoporous Materials, vol. 159, pp. 42-49, 2012.

[156] M. M. Maroto-Valer, Z. Tang, and Y. Zhang, " $\mathrm{CO}_{2}$ capture by activated and impregnated anthracites," Fuel Processing Technology, vol. 86, no. 14-15, pp. 1487-1502, 2005.

[157] X. Xu, C. Song, B. G. Miller, and A. W. Scaroni, "Adsorption separation of carbon dioxide from flue gas of natural gas-fired boiler by a novel nanoporous "molecular basket" adsorbent," Fuel Processing Technology, vol. 86, no. 14-15, pp. 1457-1472, 2005.

[158] X. Xu, C. Song, J. M. Andresen, B. G. Miller, and A. W. Scaroni, "Novel polyethylenimine-modified mesoporous molecular sieve of MCM-41 type as high-capacity adsorbent for $\mathrm{CO}_{2}$ capture," Energy and Fuels, vol. 16, no. 6, pp. 1463-1469, 2002.

[159] J. Zhang, R. Singh, and P. A. Webley, "Alkali and alkaline-earth cation exchanged chabazite zeolites for adsorption based $\mathrm{CO}_{2}$ capture," Microporous and Mesoporous Materials, vol. 111, no. 13, pp. 478-487, 2008.

[160] H. R. Abid, H. Tian, H.-M. Ang, M. O. Tade, C. E. Buckley, and S. Wang, "Nanosize Zr-metal organic framework (UiO-66) for hydrogen and carbon dioxide storage," Chemical Engineering Journal, vol. 187, pp. 415-420, 2012.

[161] C. Chen, J. Kim, and W.-S. Ahn, "Efficient carbon dioxide capture over a nitrogen-rich carbon having a hierarchical micro-mesopore structure," Fuel, vol. 95, pp. 360-364, 2012.

[162] M. G. Plaza, C. Pevida, B. Arias et al., "Application of thermogravimetric analysis to the evaluation of aminated solid sorbents for $\mathrm{CO}_{2}$ capture," Journal of Thermal Analysis and Calorimetry, vol. 92, no. 2, pp. 601-606, 2008. 
[163] A.-Y. Park, H. Kwon, A. J. Woo, and S.-J. Kim, "Layered double hydroxide surface modified with (3-aminopropyl) triethoxysilane by covalent bonding," Advanced Materials, vol. 17, no. 1, pp. 106-109, 2005.

[164] N. S. Nhlapo, "Intercalation of fatty acids into layered double hydroxides," Tech. Rep., Department of Chemistery Faculty of Natural and Agricultural sciences South Africa, University of Pretoria, 2008.

[165] M. S. Shafeeyan, W. M. A. Wan Daud, A. Houshmand, and A. Arami-Niya, "The application of response surface methodology to optimize the amination of activated carbon for the preparation of carbon dioxide adsorbents," Fuel, vol. 94, pp. 465-472, 2012.

[166] M. Clausse, J. Merel, and F. Meunier, "Numerical parametric study on $\mathrm{CO}_{2}$ capture by indirect thermal swing adsorption," International Journal of Greenhouse Gas Control, vol. 5, no. 5, pp. 1206-1213, 2011.

[167] L. Wang, Z. Liu, P. Li, J. Yu, and A. E. Rodrigues, "Experimental and modeling investigation on post-combustion carbon dioxide capture using zeolite 13X-APG by hybrid VTSA process," Chemical Engineering Journal, vol. 197, pp. 151-161, 2012.

[168] A. R. Kulkarni and D. S. Sholl, "Analysis of Equilibrium-Based TSA Processes for Direct Capture of $\mathrm{CO}_{2}$ from Air," Industrial \& Engineering Chemistry Research, vol. 51, pp. 8631-8645, 2012.

[169] J. Merel, M. Clausse, and F. Meunier, "Experimental investigation on $\mathrm{CO}_{2}$ post-combustion capture by indirect thermal swing adsorption using $13 \mathrm{X}$ and $5 \mathrm{~A}$ zeolites," Industrial and Engineering Chemistry Research, vol. 47, no. 1, pp. 209-215, 2008.

[170] S. Lucas, M. P. Calvo, C. Palencia, and M. J. Cocero, "Mathematical model of supercritical $\mathrm{CO}_{2}$ adsorption on activated carbon: effect of operating conditions and adsorption scale-up," Journal of Supercritical Fluids, vol. 32, no. 1-3, pp. 193-201, 2004.

[171] C. Hoeger, C. Bence, S. S. Burt, A. Baxter, and L. Baxter, "Cryogenic $\mathrm{CO}_{2}$ capture for improved efficiency at reduced cost," in Proceedings of the AIChE Annual Meeting, November 2010.

[172] S. Burt, A. Baxter, and L. Baxter, "Cryogenic $\mathrm{CO}_{2}$ capture to control climate change emissions," in Proceedings of the 34th International Technical Conference on Clean Coal \& Fuel Systems, May 2009.

[173] M. J. Tuinier, H. P. Hamers, and M. van Sint Annaland, "Technoeconomic evaluation of cryogenic $\mathrm{CO}_{2}$ capture-A comparison with absorption and membrane technology," International Journal of Greenhouse Gas Control, vol. 5, no. 6, pp. 1559-1565, 2011.

[174] A. Hart and N. Gnanendran, "Cryogenic $\mathrm{CO}_{2}$ capture in natural gas," Energy Procedia, vol. 1, pp. 697-706, 2009.

[175] G. Xu, L. Li, Y. Yang, L. Tian, T. Liu, and K. Zhang, "A novel $\mathrm{CO}_{2}$ cryogenic liquefaction and separation system," Energy, vol. 42, pp. 522-529, 2012.

[176] B. Shimekit and H. Mukhtar, "Natural gas purification technologies-major advances for $\mathrm{CO}_{2}$ separation and future directions," in Advances in Natural Gas Technology, A. M. Hamid, Ed., pp. 235-270, InTech, China, 2012.

[177] M. T. Ravanchi, S. Sahebdelfar, and F. T. Zangeneh, "Carbon dioxide sequestration in petrochemical industries with the aim of reduction in greenhouse gas emissions," Frontiers of Chemical Engineering in China, vol. 5, no. 2, pp. 173-178, 2011.

[178] R. P. Lively, W. J. Koros, and J. R. Johnson, "Enhanced cryogenic $\mathrm{CO}_{2}$ capture using dynamically operated low-cost fiber beds," Chemical Engineering Science, vol. 71, pp. 97-103, 2012.
[179] D. Clodic, R. El Hitti, M. Younes, A. Bill, and F. Casier, " $\mathrm{CO}_{2}$ capture by anti-sublimation thermo-economic process evaluation," in Proceedings of the 4th Annual Conference on Carbon Capture \& Sequestration, pp. 2-5, Alexandria, Va, USA, 2005.

[180] J.-M. Amann, M. Kanniche, and C. Bouallou, "Natural gas combined cycle power plant modified into an $\mathrm{O}_{2} / \mathrm{CO}_{2}$ cycle for $\mathrm{CO}_{2}$ capture," Energy Conversion and Management, vol. 50, no. 3, pp. 510-521, 2009.

[181] C.-F. Song, Y. Kitamura, S.-H. Li, and K. Ogasawara, "Design of a cryogenic $\mathrm{CO}_{2}$ capture system based on Stirling coolers," International Journal of Greenhouse Gas Control, vol. 7, pp. 107114, 2012.

[182] M. J. Tuinier, M. van Sint Annaland, and J. A. M. Kuipers, "A novel process for cryogenic $\mathrm{CO}_{2}$ capture using dynamically operated packed beds-An experimental and numerical study," International Journal of Greenhouse Gas Control, vol. 5, no. 4, pp. 694-701, 2011.

[183] P. Chiesa, S. Campanari, and G. Manzolini, " $\mathrm{CO}_{2}$ cryogenic separation from combined cycles integrated with molten carbonate fuel cells," International Journal of Hydrogen Energy, vol. 36, no. 16, pp. 10355-10365, 2011.

[184] E. Favre, "Membrane processes and postcombustion carbon dioxide capture: challenges and prospects," Chemical Engineering Journal, vol. 171, no. 3, pp. 782-793, 2011.

[185] B. Freeman and Y. Yampolskii, Membrane Gas Separation, John Wiley \& Sons, 2010.

[186] R. Bounaceur, N. Lape, D. Roizard, C. Vallieres, and E. Favre, "Membrane processes for post-combustion carbon dioxide capture: a parametric study," Energy, vol. 31, no. 14, pp. 22202234, 2006.

[187] D. Aaron and C. Tsouris, "Separation of $\mathrm{CO}_{2}$ from flue gas: a review," Separation Science and Technology, vol. 40, no. 1-3, pp. 321-348, 2005.

[188] A. Xu, A. Yang, S. Young, D. deMontigny, and P. Tontiwachwuthikul, "Effect of internal coagulant on effectiveness of polyvinylidene fluoride membrane for carbon dioxide separation and absorption," Journal of Membrane Science, vol. 311, no. 1-2, pp. 153-158, 2008.

[189] T.-L. Chew, A. L. Ahmad, and S. Bhatia, "Ordered mesoporous silica (OMS) as an adsorbent and membrane for separation of carbon dioxide $\left(\mathrm{CO}_{2}\right)$," Advances in Colloid and Interface Science, vol. 153, no. 1-2, pp. 43-57, 2010.

[190] C. A. Scholes, G. Q. Chen, G. W. Stevens, and S. E. Kentish, "Nitric oxide and carbon monoxide permeation through glassy polymeric membranes for carbon dioxide separation," Chemical Engineering Research and Design, vol. 89, no. 9, pp. 1730-1736, 2011.

[191] C. A. Scholes, S. E. Kentish, and G. W. Stevens, "Carbon dioxide separation through polymeric membrane systems for flue gas applications," Recent Patents on Chemical Engineering, vol. 1, pp. 52-66, 2008.

[192] L. A. El-Azzami and E. A. Grulke, "Carbon dioxide separation from hydrogen and nitrogen by fixed facilitated transport in swollen chitosan membranes," Journal of Membrane Science, vol. 323, no. 2, pp. 225-234, 2008.

[193] C. E. Powell and G. G. Qiao, "Polymeric $\mathrm{CO}_{2} / \mathrm{N}_{2}$ gas separation membranes for the capture of carbon dioxide from power plant flue gases," Journal of Membrane Science, vol. 279, no. 1-2, pp. $1-49,2006$.

[194] L. A. El-Azzami and E. A. Grulke, "Carbon dioxide separation from hydrogen and nitrogen: facilitated transport in arginine 
salt-chitosan membranes," Journal of Membrane Science, vol. 328, no. 1-2, pp. 15-22, 2009.

[195] G. Xomeritakis, C.-Y. Tsai, and C. J. Brinker, "Microporous sol-gel derived aminosilicate membrane for enhanced carbon dioxide separation," Separation and Purification Technology, vol. 42, no. 3, pp. 249-257, 2005.

[196] E. Favre, "Carbon dioxide recovery from post-combustion processes: can gas permeation membranes compete with absorption?" Journal of Membrane Science, vol. 294, no. 1-2, pp. 50-59, 2007.

[197] A. Julbe, "Chapter 6 Zeolite membranes-synthesis, characterization and application," Studies in Surface Science and Catalysis, vol. 168, pp. 181-219, 2007.

[198] D. W. Shin, S. H. Hyun, C. H. Cho, and M. H. Han, "Synthesis and $\mathrm{CO}_{2} / \mathrm{N}_{2}$ gas permeation characteristics of ZSM-5 zeolite membranes," Microporous and Mesoporous Materials, vol. 85, no. 3, pp. 313-323, 2005.

[199] M. Anderson and Y. S. Lin, "Carbonate-ceramic dual-phase membrane for carbon dioxide separation," Journal of Membrane Science, vol. 357, no. 1-2, pp. 122-129, 2010.

[200] D. Shekhawat, D. R. Luebke, and H. W. Pennline, "A review of carbon dioxide selective membranes," A Topical Report DOE/ NETL-2003/1200, Department of Energy, National Energy Technology Laboratory, 2003.

[201] P. Kumar, S. Kim, J. Ida, and V. V. Guliants, "Polyethyleneiminemodified MCM-48 membranes: effect of water vapor and feed concentration on $\mathrm{N}_{2} / \mathrm{CO}_{2}$ selectivity," Industrial and Engineering Chemistry Research, vol. 47, no. 1, pp. 201-208, 2008.

[202] T. C. Merkel, H. Lin, X. Wei, and R. Baker, "Power plant post-combustion carbon dioxide capture: an opportunity for membranes," Journal of Membrane Science, vol. 359, no. 1-2, pp. 126-139, 2010.

[203] Y. Cai, Z. Wang, C. Yi, Y. Bai, J. Wang, and S. Wang, "Gas transport property of polyallylamine-poly(vinyl alcohol)/polysulfone composite membranes," Journal of Membrane Science, vol. 310, no. 1-2, pp. 184-196, 2008.

[204] L. Deng, T.-J. Kim, and M.-B. Hägg, "Facilitated transport of $\mathrm{CO}_{2}$ in novel PVAm/PVA blend membrane," Journal of Membrane Science, vol. 340, no. 1-2, pp. 154-163, 2009.

[205] X. Ren, J. Ren, H. Li, S. Feng, and M. Deng, "Poly (amide-6b-ethylene oxide) multilayer composite membrane for carbon dioxide separation," International Journal of Greenhouse Gas Control, vol. 8, pp. 111-120, 2012.

[206] L. Liu, A. Chakma, and X. Feng, "Preparation of hollow fiber poly(ether block amide)/polysulfone composite membranes for separation of carbon dioxide from nitrogen," Chemical Engineering Journal, vol. 105, no. 1-2, pp. 43-51, 2004.

[207] A. Car, C. Stropnik, W. Yave, and K.-V. Peinemann, "PEG modified poly(amide-b-ethylene oxide) membranes for $\mathrm{CO}_{2}$ separation," Journal of Membrane Science, vol. 307, no. 1, pp. 8895, 2008.

[208] W. Yave, A. Car, and K.-V. Peinemann, "Nanostructured membrane material designed for carbon dioxide separation," Journal of Membrane Science, vol. 350, no. 1-2, pp. 124-129, 2010.

[209] Y. Gu and S. T. Oyama, "High molecular permeance in a poreless ceramic membrane," Advanced Materials, vol. 19, no. 12, pp. 1636-1640, 2007.

[210] M. Reif and R. Dittmeyer, "Porous, catalytically active ceramic membranes for gas-liquid reactions: a comparison between catalytic diffuser and forced through flow concept," Catalysis Today, vol. 82, no. 1-4, pp. 3-14, 2003.
[211] K. Kusakabe, T. Kuroda, and S. Morooka, "Separation of carbon dioxide from nitrogen using ion-exchanged faujasitetype zeolite membranes formed on porous support tubes," Journal of Membrane Science, vol. 148, no. 1, pp. 13-23, 1998.

[212] J. van den Bergh, W. Zhu, J. Gascon, J. A. Moulijn, and F. Kapteijn, "Separation and permeation characteristics of a DD3R zeolite membrane," Journal of Membrane Science, vol. 316, no. 12, pp. 35-45, 2008.

[213] M. P. Bernal, J. Coronas, M. Menéndez, and J. Santamaría, "Separation of $\mathrm{CO}_{2} / \mathrm{N}_{2}$ mixtures using MFI-type zeolite membranes," AIChE Journal, vol. 50, no. 1, pp. 127-135, 2004.

[214] Z. Rui, H. Ji, and Y. S. Lin, "Modeling and analysis of ceramiccarbonate dual-phase membrane reactor for carbon dioxide reforming with methane," International Journal of Hydrogen Energy, vol. 36, no. 14, pp. 8292-8300, 2011.

[215] Z. Rui, M. Anderson, Y. S. Lin, and Y. Li, "Modeling and analysis of carbon dioxide permeation through ceramic-carbonate dualphase membranes," Journal of Membrane Science, vol. 345, no. 1-2, pp. 110-118, 2009.

[216] S. J. Metz, M. H. V. Mulder, and M. Wessling, "Gas-permeation properties of poly(ethylene oxide) poly(butylene terephthalate) block copolymers," Macromolecules, vol. 37, no. 12, pp. 45904597, 2004.

[217] Z. Xu, J. Wang, W. Chen, and Y. Xu, "Separation and fixation of carbon dioxide using polymeric membrane contactor," in Proceedings of the 1st National Conference on Carbon Sequestration, 2001.

[218] D. Dortmundt and K. Doshi, Recent Developments in $\mathrm{CO}_{2}$ Removal Membrane Technology, UOP LLC, 1999.

[219] C. A. Scholes, S. E. Kentish, and G. W. Stevens, "The effect of condensable minor components on the gas separation performance of polymeric membranes for carbon dioxide capture," Energy Procedia, vol. 1, pp. 311-317, 2009.

[220] K. Hunger, N. Schmeling, H. B. Jeazet, C. Janiak, C. Staudt, and K. Kleinermanns, "Investigation of cross-linked and additive containing polymer materials for membranes with improved performance in pervaporation and gas separation," Membrane, vol. 2, pp. 727-763, 2012.

[221] S. R. Reijerkerk, "Polyether based block copolymer membranes for $\mathrm{CO}_{2}$ separation," in Science and Technology, University of Twente, Enschede, The Netherlands, 2010.

[222] A. L. B. Ahmad, Z. A. Jawad, S. C. Low, and H. S. Zein, "Prospect of mixed matrix membrane towards $\mathrm{CO}_{2}$ Separation," Journal of Membrane Science \& Technology, vol. 2, article el10, 2012.

[223] C. A. Scholes, G. Q. Chen, G. W. Stevens, and S. E. Kentish, "Plasticization of ultra-thin polysulfone membranes by carbon dioxide," Journal of Membrane Science, vol. 346, no. 1, pp. 208214, 2010.

[224] N. Du, H. B. Park, G. P. Robertson et al., "Polymer nanosieve membranes for $\mathrm{CO}_{2}$-capture applications," Nature Materials, vol. 10, no. 5, pp. 372-375, 2011.

[225] P. Uchytil, J. Schauer, R. Petrychkovych, K. Setnickova, and S. Y. Suen, "Ionic liquid membranes for carbon dioxide-methane separation," Journal of Membrane Science, vol. 383, no. 1-2, pp. 262-271, 2011.

[226] O. G. Nik, X. Y. Chen, and S. Kaliaguine, "Amine-functionalized zeolite FAU/EMT-polyimide mixed matrix membranes for $\mathrm{CO}_{2} / \mathrm{CH}_{4}$ separation," Journal of Membrane Science, vol. 379, no. 1-2, pp. 468-478, 2011.

[227] Y. C. Hudiono, T. K. Carlisle, J. E. Bara, Y. Zhang, D. L. Gin, and R. D. Noble, "A three-component mixed-matrix membrane 
with enhanced $\mathrm{CO}_{2}$ separation properties based on zeolites and ionic liquid materials," Journal of Membrane Science, vol. 350, no. 1-2, pp. 117-123, 2010.

[228] A. Kovvali and G. Obuskovic, "Immobilized liquid membranes for $\mathrm{CO}_{2}$ separation"' in Proceedings of the Preprints of SymposiaAmerican Chemical Society, pp. 665-667, Division of Fuel Chemistry, American Chemical Society, 2000.

[229] Z. Wang, L. E. K. Achenie, S. J. Khativ, and S. T. Oyama, "Simulation study of single-gas permeation of carbon dioxide and methane in hybrid inorganic-organic membrane," Journal of Membrane Science, vol. 387-388, no. 1, pp. 30-39, 2012.

[230] S.-P. Yan, M.-X. Fang, W.-F. Zhang et al., "Experimental study on the separation of $\mathrm{CO}_{2}$ from flue gas using hollow fiber membrane contactors without wetting," Fuel Processing Technology, vol. 88 , no. 5, pp. 501-511, 2007.

[231] J.-L. Li and B.-H. Chen, "Review of $\mathrm{CO}_{2}$ absorption using chemical solvents in hollow fiber membrane contactors," Separation and Purification Technology, vol. 41, no. 2, pp. 109-122, 2005.

[232] Y.-S. Kim and S.-M. Yang, "Absorption of carbon dioxide through hollow fiber membranes using various aqueous absorbents," Separation and Purification Technology, vol. 21, no. 1-2, pp. 101-109, 2000.

[233] K. Sugiura, K. Takei, K. Tanimoto, and Y. Miyazaki, “The carbon dioxide concentrator by using MCFC," Journal of Power Sources, vol. 118, no. 1-2, pp. 218-227, 2003.

[234] H. Herzog, "Assessing the feasibility of capturing $\mathrm{CO}_{2}$ from the air," Tech. Rep., MIT Laboratory for Energy and the Environment, Massachusetts Institute of Techology, Cambridge, Mass, USA, 2003.

[235] M. R. M. Abu-Zahra, J. P. M. Niederer, P. H. M. Feron, and G. F. Versteeg, " $\mathrm{CO}_{2}$ capture from power plants. Part II. A parametric study of the economical performance based on mono-ethanolamine," International Journal of Greenhouse Gas Control, vol. 1, no. 2, pp. 135-142, 2007. 

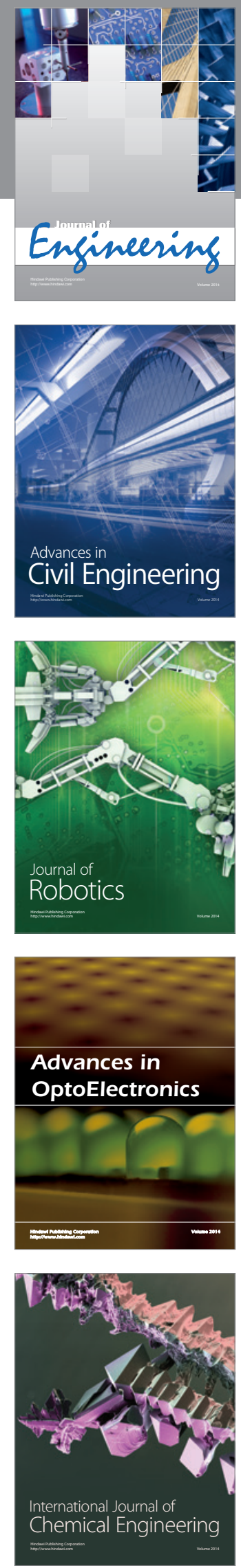

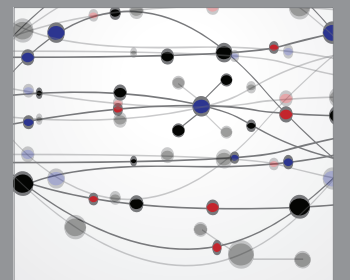

The Scientific World Journal
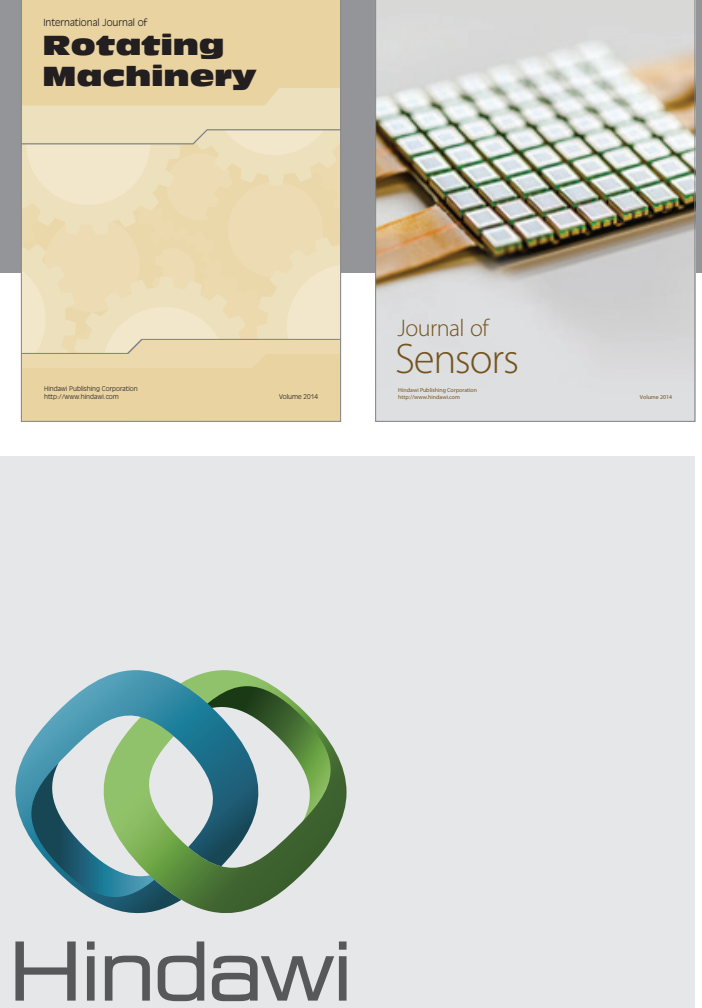

Submit your manuscripts at http://www.hindawi.com
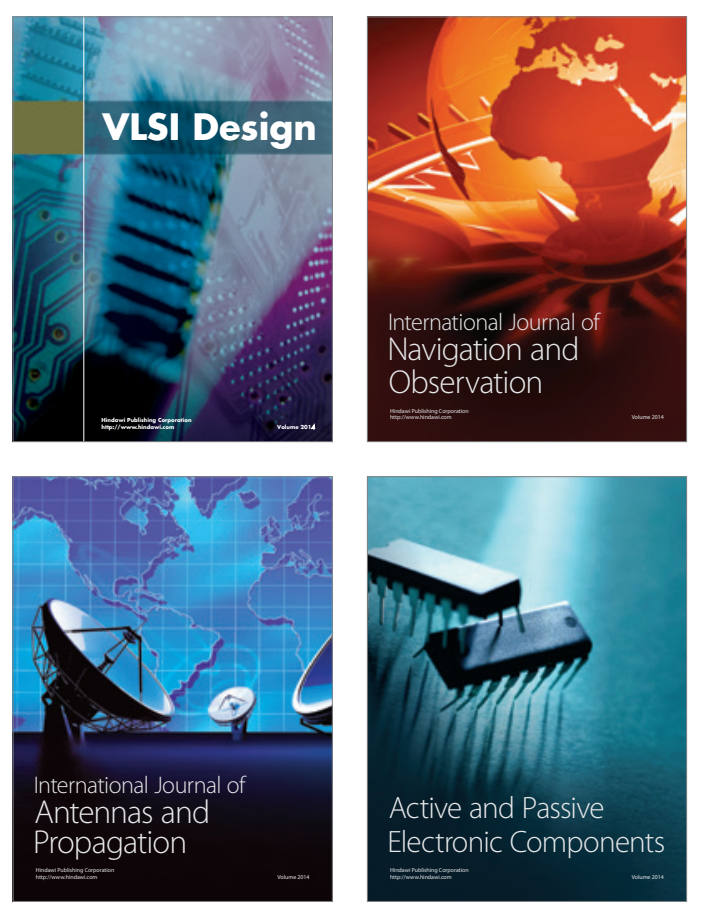
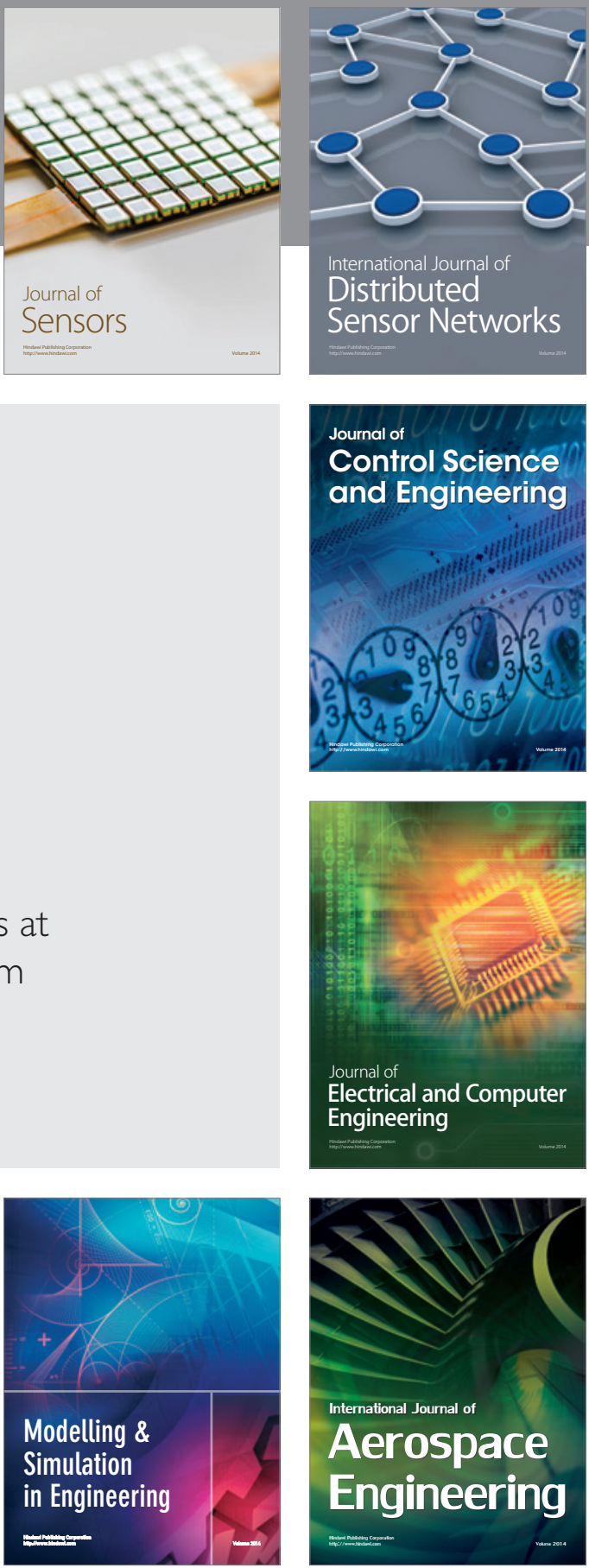

Journal of

Control Science

and Engineering
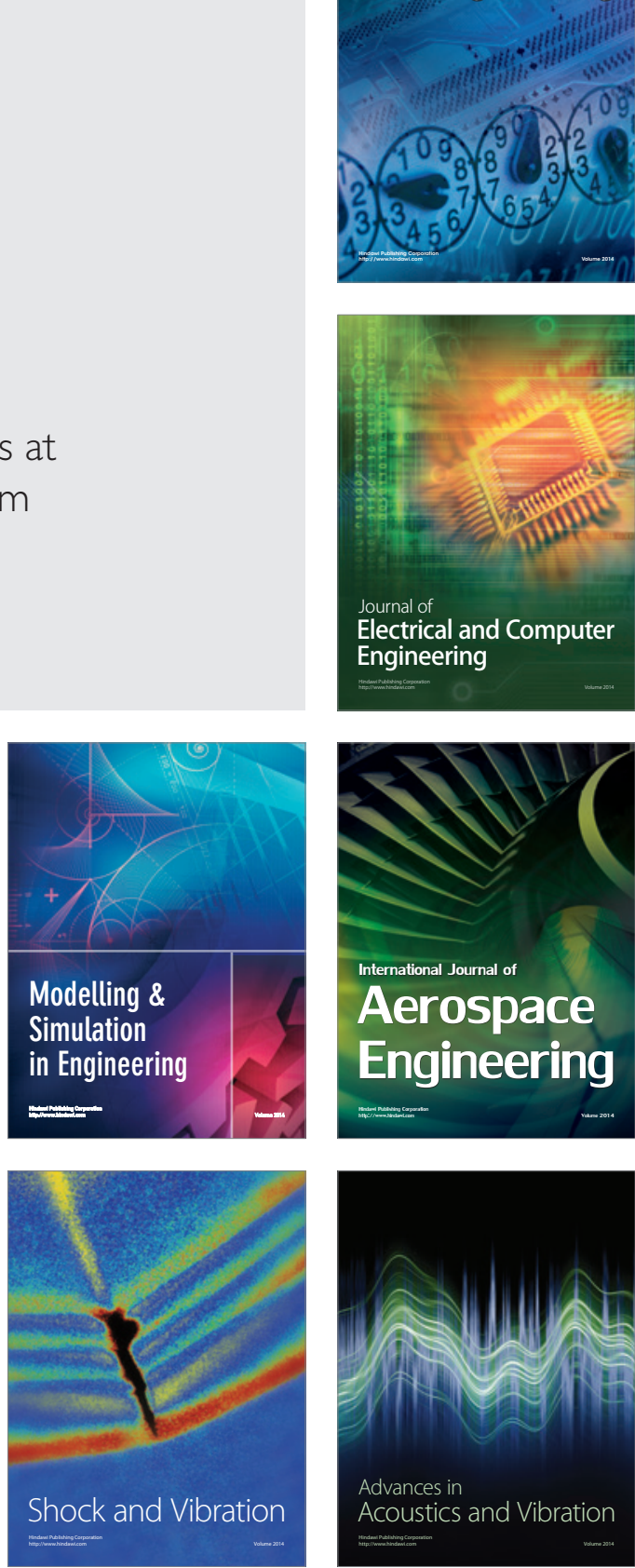